$$
\text { Pontifícia Universidade C Católica dio de Janeiro }
$$

Luiz Cláudio dos Santos

A Gênese dos Instrumentos de Promoção do Direito Fundamental à Educação Básica

Dissertação de Mestrado

Dissertação apresentada ao Programa de Pós-Graduação em Teoria do Estado e Direito Constitucional da PUC-Rio como requisito parcial para obtenção do título de Mestre em Direito.

Orientador: Prof. Francisco de Guimaraens

Rio de Janeiro

Abril de 2014 


$$
\text { Pontifícia } \text { Universidade }_{\text {Do Rio de Janeiro }}
$$

Luiz Cláudio dos Santos

\title{
A Gênese dos Instrumentos de Promoção do Direito \\ Fundamental à Educação Básica
}

\begin{abstract}
Dissertação apresentada ao Programa de Pós-Graduação em Teoria do Estado e Direito Constitucional da PUC-Rio como requisito parcial para obtenção do título de Mestre em Direito. Aprovada pela Comissão Examinadora abaixo assinada.
\end{abstract}

Prof. Francisco de Guimaraens

Orientador

Departamento de Direito - PUC-Rio

Prof. Adriano Pilatti

Departamento de Direito - PUC-Rio

Prof. Maurício de Albuquerque Rocha

Departamento de Direito - PUC-Rio

Profa. Mônica Herz

Vice-Decana de Pós-Graduação do Centro de

Ciências Sociais - PUC-Rio

Rio de Janeiro, 14 de abril de 2014 
Todos os direitos reservados. É proibida a reprodução total ou parcial do trabalho sem autorização da universidade, do autor e do orientador.

\section{Luiz Cláudio dos Santos}

Graduou-se em Direito na FABAVI (Faculdade Batista de Vitória) em 2008. Pós-graduou-se em Direito Processual na Faculdade Doctum de Vitória. É Professor Universitário da Rede de Ensino Doctum, Professor da Secretaria de Educação do Estado do Espírito Santo, Professor Orientador de EAD da Universidade Federal do Espírito Santo e do Sistema Universidade Aberta do Brasil, além de Advogado e membro da Comissão de Direitos e Prerrogativas da OAB/ES e do Comitê de Ética e Pesquisa da Escola Superior de Ciências da Santa Casa de Misericórdia de Vitória (EMESCAM).

Ficha Catalográfica

Santos, Luiz Cláudio dos

A Gênese dos Instrumentos de Promoção do Direito Fundamental à Educação Básica / Luiz Cláudio dos Santos; orientador: Francisco de Guimaraens. - Rio de Janeiro: PUC, Departamento de Direito, 2014.

v. 116 f.: il. ; $29,7 \mathrm{~cm}$

1. Dissertação (mestrado) - Pontifícia Universidade Católica do Rio de Janeiro, Departamento de Direito.

Inclui referências bibliográficas.

1. Direito - Dissertações. 2. Estado e Educação. 3. Constituinte. 4. Constituição. 5. Ideologia. 6. Lei de Diretrizes e Bases da Educação Nacional (LDB). I. Guimaraens, Francisco de (Francisco de Guimaraens). II Pontifícia Universidade Católica do Rio de Janeiro. Departamento de Direito. III. Título.

CDD: 340 
A Deus, fonte de plena sabedoria e Senhor de todas as coisas.

A minha família, que me ensinou o significado da palavra perseverança.

A Marta e Gabriel, que me ensinaram o significado da palavra amor.

A meus pais, por tudo que representam, e sempre representarão, para mim. 


\section{Agradecimentos}

Aos professores e orientadores Francisco de Guimaraens e Adriano Pilatti, meus sinceros e eternos agradecimentos pela sábia condução do árduo processo de orientação que foi marcado por várias oportunidades de reflexão e vislumbre de inusitadas e imprescindíveis perspectivas do objeto de estudo ao longo da trajetória de pesquisa e elaboração desta dissertação. Agradeço-lhes também pela grande contribuição na definição dos parâmetros deste estudo.

A todos os membros do corpo docente do Mestrado em Direito da PUC-Rio, que contribuíram de forma decisiva para a minha formação acadêmica.

À minha esposa Marta Maria Leite dos Santos e meu filho Gabriel Leite dos Santos pela indispensável compreensão devido à inevitável ausência em determinados momentos e pelo constante apoio nas horas mais difíceis desta caminhada.

Por fim, também agradeço aos meus pais, Aluízio Belarmino dos Santos e Diléia Mesquita dos Santos, pela permanente motivação e pelo incondicional encorajamento que me impulsionaram desde o início da minha trajetória acadêmica. 


\section{Resumo}

Santos, Luiz Cláudio dos; Guimaraens, Francisco de. A Gênese dos Instrumentos de Promoção do Direito Fundamental à Educação Básica. Rio de Janeiro, 2014. 116p. Dissertação de Mestrado - Departamento de Direito, Pontifícia Universidade Católica do Rio de Janeiro.

A presente dissertação investiga o legado e a influência do constitucionalismo originário da França revolucionária dos fins do século XVIII principalmente no que concerne ao direito à educação, a partir das suas origens históricas, filosóficas, políticas, ideológicas, jurídicas e socioeconômicas. Inicialmente examina-se o advento dos direitos civis e políticos e seus reflexos na perspectiva educacional revolucionária francesa. Em seguida, estuda-se o direito à educação proveniente do poder constituinte. Analisa-se a educação no contexto da transição da democracia para a ditadura revolucionária francesa. Pesquisa-se ainda a função social da educação como espaço de disputas de forças ligadas a interesses sociopolíticos antagônicos no âmbito do Capitalismo contemporâneo. Analisamse os processos que caracterizam a escola como instrumento da emancipação humana. Por outro lado, considerando o caráter ambivalente da educação, examinam-se também os fundamentos e efeitos da dominação perpetrada pela elite burguesa capitalista mediante a manipulação da educação. Propõe-se uma reflexão sobre os processos que caracterizam a escola como instrumento do Poder Disciplinar e da dominação perpetrada pela burguesia mediante a utilização dos Aparelhos Ideológicos de Estado (AIE). Finalmente, empreende-se um exame histórico da abordagem constitucional do tema educação ao longo da história do constitucionalismo brasileiro. Investigam-se os embates políticos e ideológicos travados em torno desse tema na Assembléia Nacional Constituinte de 1987-1988, assim como nas comissões que discutiram o projeto que resultou na atual Lei de Diretrizes e Bases da Educação.

\section{Palavras-chave}

Estado e Educação; Constituinte; Constituição; Ideologia; Lei de Diretrizes e Bases da Educação Nacional (LDB). 


\section{Abstract}

Santos, Luiz Cláudio dos; Guimaraens, Francisco de (Advisor). The Genesis of the Instruments for the Promotion of the Fundamental Right to Basic Education. Rio de Janeiro, 2014. 116p. Dissertação de Mestrado Departamento de Direito, Pontifícia Universidade Católica do Rio de Janeiro.

This dissertation investigates the legacy and influence of revolutionary constitutionalism originating in France of the late eighteenth century especially regarding the right to education from its historical, philosophical, political, ideological, legal and socioeconomic backgrounds. Initially, it examines the emergence of civil and political rights and their effects in the French revolutionary educational perspective. Then it investigates the right to education originating from the constituent power. It analyzes education in the transition from democracy to the French revolutionary dictatorship. It also explores the social function of education as an area of struggle among opposing forces with sociopolitical interests under contemporary Capitalism. It examines the processes that characterize school as an instrument of human emancipation. Moreover, considering the ambivalent character of education, it also analyzes the reasons and effects of domination perpetrated by the capitalist bourgeois elite by manipulating education. It explores the processes that characterize the school as an instrument of disciplinary power and domination perpetrated by the bourgeoisie through the use of the Ideological State Apparatuses. Finally, it examines historically the constitutional approach to education throughout the history of Brazilian constitutionalism. It investigates the political and ideological clashes on this issue in the National Constituent Assembly of 1987-1988, as well as on committees that discussed the project that resulted in the National Educational Bases and Guidelines Law.

\section{Keywords}

State and Education; Constituent (Power and Assembly); Constitution; Ideology; National Educational Bases and Guidelines Law (LDB). 


\section{Sumário}

Introdução

1. Origens Políticas do Direito Fundamental à Educação

1.1 O Advento dos Direitos Civis e Políticos no Constitucionalismo Originário Francês e seus Reflexos na Perspectiva Educacional Revolucionária 17

1.2 O Direito à Educação Proveniente do Poder Constituinte

1.3 A Educação no Contexto da Transição da Democracia para a Ditadura Revolucionária Francesa

2. A Educação como Locus de Disputa Ideológica no Contexto do Estado Capitalista 36

2.1 A Educação como Instrumento de Dominação Burguesa

2.2 A Educação para Reintegração da Onilateralidade e Emancipação Humana à Luz do Materialismo Histórico

2.3 A Educação como Aparelho Ideológico do Estado

2.4 A Educação na Sociedade Disciplinar

3 O Processo de Formação dos Instrumentos de Promoção do Direito Fundamental à Educação Básica

3.1 Uma Análise Retrospectiva da Abordagem da Educação ao Longo da História do Constitucionalismo Brasileiro

3.2 O Cenário Político dos Debates e Embates em Torno do Teor da Seção da Educação nas Comissões da Constituinte

3.3 A Dinâmica do Contexto Parlamentar Gerador da Lei de Diretrizes

e Bases da Educação Nacional (LDB)

4 Considerações Finais 
É no problema da educação que assenta o grande segredo do aperfeiçoamento da humanidade.

Immanuel Kant 


\section{Introdução}

Embora o paradigma constitucional que caracterizou o constitucionalismo do século XVIII não seja o mesmo da estrutura constitucional brasileira contemporânea, alguns dos seus elementos têm sido continuamente ratificados ao longo da evolução da teoria constitucional pátria.

Assim, partindo dessa hipótese que pressupõe a influência do constitucionalismo originário da Revolução Francesa na concepção do atual direito à educação básica, além de supor a natureza ambivalente da educação como elemento que possui a dupla potencialidade de promover a transformação social ou de manipular e controlar o homem, a presente dissertação visa analisar, precipuamente, o processo de discussão e elaboração de dois diplomas normativos garantidores do direito fundamental à educação básica.

Tais instrumentos normativos são a Constituição da República Federativa do Brasil, promulgada em 5 de outubro de 1988 e a Lei $n^{\circ}$ 9.394, de 20 de dezembro de 1996 (LDB), que estabelece as diretrizes e bases da educação nacional. Esse cenário hipotético motivou o estudo que culminou na redação da presente dissertação em virtude da produção de inquietações que foram traduzidas nessas questões norteadoras.

Deste modo, o presente trabalho propõe-se, sobretudo, a investigar quais foram os específicos pontos de conflito que provocaram embates ou enfrentamentos políticos ocorridos em torno da temática da educação básica tanto na Assembleia Nacional Constituinte de 1987-1988 quanto no Congresso Nacional no período de deliberação sobre a LDB. Em outras palavras, analisa-se o contexto de tensão existente entre os parlamentares representantes ou alinhados com perspectivas conservadoras ou progressistas de educação defendidas por correntes político-ideológicas dotadas de interesses diametralmente opostos.

Visando alcançar esse objetivo principal, traçou-se uma rota que abrange questões cruciais envolvidas nesse processo de concepção do aparato jurídico promotor do direito à educação básica no Brasil. Conforme mencionado anteriormente, esse percurso inclui o exame do legado resultante do contexto histórico e político-ideológico da França revolucionária do final do século XVIII, 
que caracterizou-se pela mesma dicotomia entre vertentes políticas progressistas e conservadoras constatada no cenário parlamentar brasileiro supracitado. Portanto, pressupõe-se que os fundamentos filosóficos e políticos do direito à educação podem ser identificados como oriundos do período embrionário do constitucionalismo marcado pelo advento da Revolução Francesa. Presume-se que seria possível reconhecer a ressonância dos embates revolucionários franceses concernentes à concepção de educação em nossa contemporaneidade políticoideológica que tem implicações diretas na qualidade e no acesso ao ensino básico.

Além disso, nesse mesmo diapasão destaca-se a ênfase no estudo do suposto caráter ambivalente da educação, ou seja, sua potencialidade de assumir qualquer uma das duas funções radicalmente opostas de promotora da emancipação ou do controle do homem. Portanto, busca-se investigar se tal ambivalência seria uma propriedade inerente à educação que, como uma “faca de dois gumes”, pode ser instrumentalizada de acordo com a ênfase progressista ou conservadora promovida segundo os interesses e a posição político-ideológica dos detentores do poder. Em outras palavras, tratou-se de examinar se por um lado ela pode ser considerada como um elemento de reintegração da onilateralidade e da emancipação humana, e por outro lado pode ser transformada em um instrumento de dominação burguesa e aparelho ideológico do Estado capitalista no âmbito da sociedade disciplinar.

Portanto, o presente estudo, sem pretender esgotar o objeto da discussão, propõe-se a explorar as bases históricas, sociais, econômicas, políticas, ideológicas e jurídicas que permearam os debates e confrontos parlamentares que culminaram na elaboração e consolidação desses instrumentos de promoção do direito fundamental à educação básica. Assim, justifica-se a pertinência tanto técnico-científica quanto social desta dissertação em virtude do papel relevante da educação na formação do cidadão brasileiro, assim como a sua posição de importância na atual Constituição Federal e na Lei no 9.394/96.

Além disso, a relevância deste estudo também se sustenta pelas consequências ou pelos reflexos gerados pela adoção das perspectivas e dos ideais prevalecentes defendidos pelas vertentes que predominaram no processo de formulação das supracitadas normas e que, consequentemente, determinam o rumo das políticas públicas para a educação básica. Ainda à guisa de justificativa 
para a escolha do presente tema, algumas considerações devem ser enfatizadas. A primeira razão para a adoção dessa temática é a posição de superlativa relevância que atribuo à educação em virtude do papel decisivo exercido por ela na alteração da minha trajetória de vida. A sua incomparável valorização deve-se pela sua potencialidade de revelar um universo de possibilidades de ação no mundo até então considerados inalcançáveis aos meus olhos de filho das classes subalternas. Ao descortinar as janelas do conhecimento, a educação tem viabilizado a descoberta de horizontes inimagináveis. Inegavelmente, essas são perspectivas inusitadas que têm enriquecido todos os âmbitos da minha existência.

A segunda motivação para refletir, investigar, pesquisar e redigir uma dissertação de mestrado com esse tema foi exatamente a minha vocação para o ensino. De fato, ao longo desses 23 anos de carreira como educador tenho vivido experiências ambivalentes que têm me provocado uma grande e permanente inquietação no que tange ao direito à educação. Tais situações me estimulam constantemente a continuar pesquisando e buscando aprofundamento no estudo desse tema específico.

Deste modo, se por um lado tenho tido o prazer de acompanhar o inegável desenvolvimento intelectual e cultural de vários dos meus alunos que se encantam como atores do processo de produção do conhecimento ensejado pelo acesso à educação básica, por outro lado também tenho testemunhado com pesar os efeitos danosos do descaso com que a educação é tratada no Brasil.

Em outras palavras, como professor de uma escola pública de ensino médio, tenho vivenciado as consequências desse menosprezo do Poder Público pela educação que se traduz no abandono da escola e daqueles que nela atuam. Contudo, apesar das carências, insuficiências, ausências e privações, ainda há abnegados educadores que dedicam-se na superação dos inúmeros obstáculos e levam seus alunos ao alcance de resultados dignos de louvor.

Assim, desde o curso de bacharelado em direito tenho me dedicado ao estudo desse direito fundamental. Pois, através da educação, o indivíduo pode compreender o alcance de seus direitos e a magnitude de suas liberdades. Isto é, a educação enseja ao cidadão o conhecimento da possibilidade de exigência e do exercício dos seus direitos e garantias fundamentais. 
Ademais, a educação revela a importância da observância de seus deveres, assim como viabiliza a sua integração na sociedade baseada na democracia participativa. Em essência, a educação funcionaria como um passaporte imprescindível para o exercício da plena cidadania. A educação é um pressuposto para a evolução de qualquer Estado de democrático de direito, pois além da mera contribuição na qualificação para o trabalho, ela cooperar para a formação da capacidade crítica dos cidadãos.

Além disso, recordo com nostalgia que tal profundo interesse pela educação remonta às décadas de 1970 e 1980, quando era aluno de escolas públicas de educação básica situadas na cidade do Rio de Janeiro. Realmente, tendo estudado apenas em escolas públicas em função da insuficiência de recursos financeiros para arcar com os custos de matrícula e mensalidades de colégios da iniciativa privada, foi exatamente em instituições escolares públicas que iniciei meus contatos com o saber. Desde então a escola tornou-se um local onde encontro prazer ao descobrir novos conhecimentos.

Inclusive, essa intensa paixão pelo saber e pelo conhecimento se traduziu em ação militante com a minha participação direta nos pacíficos protestos realizados por centenas de estudantes de universidades públicas oriundos das mais diversas unidades da federação no ano de 1988 em Brasília.

Realmente, orgulho-me ao afirmar que tive o privilégio de marcar presença entre aqueles jovens idealistas que embarcaram rumo à capital federal. Com nostalgia, recordo que mais de vinte ônibus partiram do campus da Universidade Federal do Rio de Janeiro na Ilha do Fundão e desembarcaram no Planalto exatamente no período de discussão e deliberação parlamentar concernente ao direito à educação no Congresso Nacional. A missão daqueles cidadãos universitários era pressionar os membros da Assembleia Nacional Constituinte para que assegurassem o direito à educação pública, universal, gratuita e laica no texto da então futura Carta Magna.

O direito à educação é considerado como uma prerrogativa jurídica fundamental que, em decorrência, impõe ao Estado, em virtude da alta significação social de que se reveste, a obrigação constitucional de criar condições objetivas que possibilitem, de maneira concreta, o efetivo acesso a todos os 
cidadãos ao sistema educacional. Caso contrário, o Poder Público incorre no risco de ocasionar inaceitável omissão inconstitucional, apta a frustrar, injustamente, por sua inércia, o integral adimplemento da prestação estatal que lhe impôs o próprio texto da Constituição Federal.

Portanto, à luz dessa consagração do direito à educação tanto na Carta Magna quanto na Lei de Diretrizes e Bases da Educação Nacional, surgiu o interesse de pesquisar a dinâmica dos processos ideológicos, políticos e parlamentares envolvidos na gênese dessas normas. Pois, por ventura, a análise dos contextos ou cenários nos quais tais normas foram geradas - marcados por embates político-ideológicos entre forças conservadoras e correntes progressistas - possa fornecer subsídios não só para a compreensão da situação atual da educação, mas também contribuir para a descoberta de novas vias que possibilitem a efetividade desse direito fundamental.

À vista disso, acolhendo as luzes das contribuições de relevantes pensadores da ciência política, da filosofia, do direito constitucional e da educação, no primeiro capítulo apresentam-se as origens históricas, sociais, econômicas e políticas do direito fundamental à educação básica. Pesquisa-se a origem do direito à educação, examinando-se o advento dos direitos civis e políticos no constitucionalismo francês e seus reflexos na perspectiva educacional revolucionária.

Ademais, discute-se como as diferentes e marcantes fases da Revolução Francesa contribuíram para instituir os direitos civis e políticos ao longo do processo revolucionário marcado pela transição da democracia para a ditadura revolucionária. Portanto, investiga-se como tal perspectiva influenciou a concepção de educação como promotora do novo homem destinado a conviver na inusitada ordem sociopolítica.

Deste modo, empreende-se um exame dos fundamentos históricos e políticos, filosóficos e sociais de institutos constitucionais como direitos civis, direitos políticos e poder constituinte, que podem ter influenciado o processo legislativo produtor desses dois textos normativos.

Além disso, estuda-se o direito à educação proveniente do poder constituinte, enfatizando-se o seu papel na discussão e elaboração dos 
supramencionados diplomas legais brasileiros destinados a promover o direito à educação. Também analisa-se a educação no contexto da transição da democracia para a ditadura revolucionária francesa.

Deste modo, visando alcançar os objetivos deste estudo, analisa-se o panorama político revolucionário francês do final do século XVIII, no qual verificou-se um intenso conflito de interesses entre os jacobinos (progressistas radicais) e os girondinos (representantes da alta burguesia conservadora). Evidentemente, se esses grupos políticos antagônicos possuíam perspectivas opostas em relação aos encaminhamentos revolucionários, suas concepções relativas à função da educação na construção da nova nação francesa também eram contrárias.

Em outras palavras, por um lado os jacobinos defendiam a educação básica universal, obrigatória, gratuita e laica com base em princípios republicanos e igualitários. Por outro lado, os conservadores girondinos, defensores dos interesses e os ideais da alta burguesia francesa, uma vez no poder após o Termidor, trataram de revogar a lei que garantia a educação gratuita e estabelecer medidas políticas mais conservadoras em relação ao ensino.

Em seguida, no segundo capítulo estuda-se a realidade da educação como locus de disputa ideológica no contexto do Estado capitalista e instrumento de dominação burguesa. Portanto, pesquisa-se a função social da educação como espaço de disputas de forças ligadas a interesses sociopolíticos antagônicos no âmbito do Capitalismo contemporâneo. Assim, pretende-se investigar a função ambivalente que a educação pode desempenhar, seja quando está a serviço da expansão do acesso democrático à escola, seja quando está apenas ao sabor de classes sociais hegemônicas.

Em outras palavras, por um lado discute-se e trata-se da relevância da educação para reintegração da onilateralidade e emancipação social do homem à luz da perspectiva filosófica do materialismo histórico. Contudo, por outro lado, empreende-se um exame da educação como um dos Aparelhos Ideológicos do Estado, assim como investiga-se o seu papel como um direito fundamental na sociedade disciplinar. 
Além disso, considerando-se as bases constitucionais que elevam o direito à educação ao patamar de direito fundamental, no terceiro capítulo, preliminarmente, contemplando-se a conexão entre as tradições constitucionalistas com atual modelo constitucional, apresenta-se um panorama retrospectivo do tratamento do tema educação básica ao longo da história do constitucionalismo brasileiro.

Assim, analisa-se o cenário político dos debates e embates em torno do teor da seção da educação nas comissões da Assembleia Constituinte de 1987-1988. Em seguida, examina-se a dinâmica do contexto parlamentar gerador da atual Lei de Diretrizes e Bases da Educação Nacional.

Deste modo, à luz de todo o exposto, busca-se investigar se a ordem social e a concepção de educação defendidas por esses grupos políticos são estruturadas segundo os interesses da classe burguesa e não refletem as necessidades das camadas sociais mais desfavorecidas, perpetuando, assim a segregação mediante a monopolização do sistema educacional.

Finalmente, parte-se do pressuposto de que a apreciação das conquistas doutrinárias do passado típicas dessa fase histórica do constitucionalismo mundial e nacional pode viabilizar a compreensão do presente e contribuir para a idealização de um futuro melhor para a educação básica.

Este estudo foi realizado mediante o emprego de metodologia teóricodedutiva e pesquisa bibliográfica de obras pertinentes ao âmbito do Direito Constitucional, Educação, História e Ciência Política, além da análise de atas das comissões instaladas na Assembleia Nacional Constituinte (ANC) de 1987-1988 e no Congresso Nacional por ocasião do processo legislativo que culminou com a promulgação da Lei de Diretrizes e Bases da Educação Nacional (LDB). 


\section{1}

\section{Origens Políticas do Direito Fundamental à Educação}

1.1

O Advento dos Direitos Civis e Políticos no Constitucionalismo Originário Francês e seus Reflexos na Perspectiva Educacional Revolucionária

É imprescindível considerar os acontecimentos que precipitaram a Revolução Francesa na análise da evolução do constitucionalismo que posteriormente culminou na adoção e consagração do direito à educação. Assim, considerando a indivisibilidade e a interdependência dos direitos humanos, visando uma melhor compreensão da relevância desse direito fundamental no aparato jurídico pátrio é oportuno um exame do surgimento dos direitos civis e políticos no contexto de efervescência sociopolítica da França revolucionária.

No final do século XVIII, a realeza buscava garantir os privilégios e a luxuosa vida de corte da nobreza. Porém, tais interesses, além de exigir grandes gastos aos cofres estatais, mantinha a burguesia excluída do poder político. Por conseguinte, as altas e crescentes despesas com a nobreza e os prejuízos advindos de guerras desencadearam a crise financeira do Estado absolutista francês. Consequentemente, o déficit orçamentário crônico só poderia ser sanado por uma reforma tributária que abolisse a isenção de impostos e outros privilégios do clero e da nobreza, assim como também a exclusividade na ocupação de certos cargos públicos e pensões do Estado.

Por sua vez, contrariados por serem os únicos pagantes dos altos impostos que custeavam os privilégios do clero e da nobreza, elementos do Terceiro Estado começaram a reivindicar a igualdade de todos perante a lei. Simultaneamente, a burguesia, cada vez mais consciente de seus interesses e potencialidades, defendia uma reforma estatal e social que implicaria em "combater o absolutismo monárquico, a excessiva intervenção na economia, a intolerância filosófica e religiosa e os privilégios hereditários da nobreza e do clero, entre outras coisas.”1

Pressionado pela aristocracia ameaçada em seus privilégios tradicionais, e

${ }^{1}$ COTRIM, G. História global - Brasil e geral. 8. ed. São Paulo: Saraiva, 2005, p. 292. 
incapaz de conter a "anarquia, os conflitos e a matança indiscriminada nas ruas"2, Luís XVI convoca a Assembleia dos Estados Gerais (composta por deputados representantes de Nobres, do Alto Clero e do Terceiro Estado) para ajudá-lo a forçar o Terceiro Estado a assumir novos impostos.

A revolução avançou sob o comando da burguesia estimulada por ideais filosóficos iluministas e pela doutrina liberal. A crescente insatisfação popular culminou em uma série de acontecimentos históricos sem precedentes: a "Queda da Bastilha”, a execução dos monarcas, o confisco dos bens da Igreja Católica, extinção de direitos e privilégios feudais e a promulgação da Declaração dos Direitos do Homem e do Cidadão de 1789, que preconizava os direitos civis e políticos de todos os cidadãos.

Ao longo de sua apreciação da evolução histórica dos Direitos Humanos, Comparato assinala a relevância do ideário da Revolução Francesa na abolição de privilégios aristocráticos e na consolidação dos direitos civis e políticos de todos os cidadãos, enfatizando o surgimento e a concretização de valores tais como a liberdade, a igualdade e a fraternidade. Realçando a importância do movimento revolucionário francês como um evento cuja magnitude não tem precedentes na História e com reflexos nos dias atuais, ele enfatiza que

A Revolução Francesa desencadeou, em curto espaço de tempo, a supressão das desigualdades entre indivíduos e grupos sociais, como a humanidade jamais experimentou até então. Na tríade famosa, foi sem dúvida a igualdade que representou o ponto central do movimento revolucionário. A liberdade, para os homens de 1789, limitava-se praticamente à supressão de todas as peias sociais ligadas à existência de estamentos ou corporações de ofícios. E a fraternidade, como virtude cívica, seria o resultado necessário de absolvição de todos os privilégios. $^{3}$

Por sua vez, o historiador britânico Eric Hobsbawm avalia a Revolução Francesa como um movimento político e social marcante com repercussões e consequências incomparáveis e profundas para a democracia universal. ${ }^{4}$ Considerando-a como uma revolução burguesa, uma vez que, paulatinamente, esse grupo social emergente passou a controlar o poder político, ele conclui que os dirigentes do novo regime passaram a se identificar "como uma classe média, e a

${ }^{2}$ ODALIA, N. A liberdade como meta coletiva. In: PINSKY, J.; PINSKY, C. B. (Org.). História da cidadania. 4. ed. São Paulo: Contexto, 2008, p. 164.

${ }^{3}$ COMPARATO, F. K. A afirmação histórica dos direitos humanos. 7. ed. São. Paulo: Saraiva, 2010, p. 148.

${ }^{4}$ HOBSBAWM, E. J. A era das revoluções: 1789-1848. Rio de Janeiro: Paz e Terra, 1981, p. 71. 
reconhecer a Revolução como uma luta de classes tanto contra a aristocracia quanto contra os pobres". ${ }^{5}$ Inclusive, é interessante notar que, contemplando as deficiências burguesas do movimento revolucionário, Hobsbawm referiu-se à Declaração dos Direitos do Homem e do Cidadão de 1789 como "um manifesto contra a sociedade hierárquica de privilégios nobres, mas não um manifesto a favor de uma sociedade democrática e igualitária."6

Por outro lado, focando este mesmo ponto da argumentação, em contraposição, cumpre salientar a posição conservadora e indignada do filósofo Edmund Burke que, em sua clássica crítica, acusa os revolucionários franceses de pervertidos que estariam tão ocupados com suas teorias sobre os direitos do homem que haviam se esquecido totalmente da natureza humana. Vale destacar a maestria de Burke ao descrever o quadro de horror social na frança revolucionária.

\begin{abstract}
Eles encontraram seu castigo no seu próprio sucesso: leis não cumpridas e tribunais destituídos; a indústria aniquilada e o comércio se extinguindo; impostos não pagos, e no entanto, o povo empobrecido; a Igreja pilhada sem que o Estado se beneficie com isto; a anarquia civil e militar transformada em constituição do reino; todas as coisas divinas e humanas sacrificadas ao ídolo do crédito público cuja consequência é a bancarrota nacional; e para coroar tudo isto, o papel-moeda emitido por um poder novo, precário e titubeante, $[\ldots]^{7}$
\end{abstract}

Segundo ele, considerando-se as circunstâncias na conjuntura supramencionada, a Revolução Francesa seria o acontecimento mais aterrorizante já ocorrido no mundo. Deste modo, tudo parecia fora da natureza em um estranho caos de insensatez e ferocidade no qual todos os tipos de crimes se misturavam a todos os tipos de loucura. Conspirações, assassinatos e massacres juntos representariam um preço banal para o sucesso de uma revolução ao invés de uma insípida reforma sem derramamento de sangue.

Inclusive, em seu sombrio e pessimista relato, Burke parece assombrado “pelos gritos, pelo tumulto e pela agitação, seja pelo medo, por eles provocado, dos complôs e das invasões, procuram aplacar as lamúrias dos indigentes e desviar os olhares dos observadores da ruína e da miséria do Estado”8

Assim, opondo-se à doutrina iluminista, consequentemente, Burke rejeita

${ }^{5}$ HOBSBAWM, E. J. Ecos da Marselhesa: dois séculos reveem a Revolução Francesa. São Paulo: Companhia das Letras, 1996, p. 39.

${ }^{6}$ HOBSBAWM, E. J. A era das revoluções: 1789-1848. Rio de Janeiro: Paz e Terra, 1981, p. 77.

${ }^{7}$ BURKE, E. Reflexões sobre a revolução em França. Brasília: UnB, 1982, p. 74.

${ }^{8}$ Idem, p. 141. 
com veemência o ideário do movimento revolucionário francês. Por julgar que as ações extremas e violentas dessa Revolução poderiam solapar as bases sobre as quais uma sociedade livre se sustenta, ele chegou a expressar sua certeza de que, “em uma democracia, a maioria dos cidadãos é capaz de exercer as opressões mais cruéis sobre a minoria."9

Contudo, no que tange aos reflexos da ideologia revolucionária francesa nos princípios constitucionais democráticos brasileiros, ressalte-se a concepção de Estado Democrático de Direito adotada pela Constituição Federal de 1988. Pois, a democracia, “como realização de valores (igualdade, liberdade e dignidade da pessoa) de convivência humana, é conceito mais abrangente do que o de Estado de Direito, que surgiu como expressão jurídica da democracia liberal.”10

Inclusive, exemplificando tal legado liberal, cumpre destacar alguns princípios fundamentais preconizados no artigo $1^{\circ}$ da Constituição Federal de 1988 cuja origem remonta ao conjunto de ideais basilares e estruturais que caracterizou a Revolução Francesa.

A cidadania está aqui num sentido mais amplo do que o de titular de direitos políticos. Qualifica os participantes da vida do Estado, o reconhecimento do indivíduo como pessoa integrada na sociedade estatal (art. 5º LXXVII). Significa aí, também, que o funcionamento do Estado estará submetido à vontade popular. E aí o termo conexiona-se com o conceito de soberania popular (parágrafo único do art. $1^{\circ}$ ), com os direitos políticos (art. 14) e com o conceito de dignidade da pessoa humana (art. $1^{\circ}$, III), com os objetivos da educação (art. 205), como base e meta essencial do regime democrático.[...] Dignidade da pessoa humana é um valor supremo que atrai o conteúdo de todos os direitos fundamentais do homem, desde o direito à vida. Concebido como referência constitucional unificadora de todos os direitos fundamentais [...] Finalmente, o inc. V do art. $1^{\circ}$ da Constituição inclui o pluralismo político também como fundamento do Estado Democrático de Direito. O pluralismo está referido em diversos dispositivos da Constituição o que mostra que ela optou pela sociedade pluralista que respeita a pessoa humana e sua liberdade, em lugar de uma sociedade monista que mutila os seres e engendra as ortodoxias opressivas. O pluralismo é uma realidade, pois a sociedade se compõe de uma pluralidade de categorias sociais, de classes, grupos sociais, econômicos, culturais e ideológicos. ${ }^{11}$

É em virtude do movimento revolucionário francês e em decorrência da influência dos ideais inseridos na primeira Declaração dos Direitos do Homem e do Cidadão de 1789, que os direitos humanos são reafirmados. Em outras

\footnotetext{
${ }^{9}$ BURKE, E. Reflexões sobre a revolução em França. Brasília: UnB, 1982, p. 135.

${ }^{10}$ SILVA, J. A. Princípios constitucionais fundamentais. In: 20 anos da constituição cidadã. Cadernos Adenauer IX. Rio de Janeiro: Fundação Konrad Adenauer, 2008, p. 12.

${ }^{11}$ Idem, p. 12-14.
} 
palavras, tais direitos "entendidos como o mínimo ético necessário para a realização do homem, na sua dignidade humana, reassumem posição de destaque» $^{\# 12}$ na ordem constitucional. Assim, a partir desse marco histórico iniciado com a deflagração da Revolução Francesa, pelo menos teoricamente, todos os cidadãos passam a ser reconhecidos como possuidores dignidade como titulares de direitos fundamentais, independentemente de suas características pessoais ou de seu status social.

A propósito, essa evolução da perspectiva da dignidade da pessoa humana que pode ser observada ao longo do século XVIII foi seguida pelo movimento de propagação de ideais que resultou no constitucionalismo. Inclusive, é válido ressaltar, portanto, que os "direitos fundamentais, nesse contexto, foram produto das revoluções burguesas do final do século XVIII e integraram as constituições modernas como forma de proteção jurídica da liberdade e da propriedade.”13

Assim, conclui-se que a afirmação histórica da primeira geração ou dimensão de direitos humanos, classificados como direitos civis e políticos, coincidiu com as aspirações liberais e democráticas das camadas populares na França revolucionária em sua luta contra os privilégios dos aristocratas e a exploração dos plebeus.

No que tange à relação entre a Revolução Francesa e o ensino, não há como ignorar a contribuição de expoentes do pensamento pedagógico iluminista no início dessa nova era na história da educação. Rousseau destacou-se dentre os enciclopedistas por restaurar uma vinculação entre a educação e a política.

Aliás, pode-se observar que o "século XVIII é político-pedagógico por excelência”"14, em virtude da justa demanda das classes populares por acesso ao conhecimento por meio da escola pública. Inclusive, antes do período da Revolução Francesa jamais havia se debatido tanto sobre a efetivação da educação ou da formação dos cidadãos por meio de instituições escolares públicas. ${ }^{15}$

\footnotetext{
${ }^{12}$ OLIVEIRA, E. P. Processo e hermenêutica na tutela penal dos direitos fundamentais. Belo Horizonte: Del Rey, 2004, p. 12.

${ }^{13}$ PEDUZZI, M. C. I. O princípio da dignidade da pessoa humana na perspectiva do direito como integridade. São Paulo: LTr, 2009, p. 21.

${ }^{14}$ GADOTTI, M. História das ideias pedagógicas. 6. ed. São Paulo: Ática, 1998, p. 88.

${ }^{15}$ Idem, p. 87-88.
} 
A escola pública é filha dessa revolução burguesa. Os grandes teóricos iluministas pregavam uma educação cívica e patriótica inspirada nos princípios da democracia, uma educação laica, gratuitamente oferecida pelo Estado para todos. Tem início com ela a ideia da unificação do ensino público em todos os graus. Mas ainda era elitista: só os mais capazes podiam prosseguir até a universidade. ${ }^{16}$

Assim, buscando emancipar o pensamento da repressão dos soberanos déspotas e da manipulação repressora da Igreja, o iluminista Rousseau pregava um retorno ao estado natural de liberdade experimentado pelo "bom selvagem" que, na prática, somente poderia ser vivenciado por poucos privilegiados livres em virtude da exploração do trabalho alheio.

Contudo, o Emílio criado por Rousseau personifica esse ideal de homem primitivo, que teria sido educado apenas em contato com o próprio autor como seu preceptor. Considerado um precursor da escola nova, acreditava que a educação deveria ir além da mera instrução ao permitir que "a natureza desabrochasse na criança” sem repressão ou modelagem. ${ }^{17}$

Assim, ao longo do período da Revolução Francesa, “Emílio”, o tratado rousseauniano sobre o novo pensamento político-pedagógico inspirou a consolidação do novo sistema educacional pátrio. A partir da ênfase na educação desimpedida e espontânea, Rousseau delineava os principais elementos da sua filosofia educacional, criticando as condições inapropriadas das poucas instituições de instrução pública daquela época.

A instituição pública não existe mais, e não pode mais existir, porque não há mais pátria, não pode haver cidadãos. Estas duas palavras pátria e cidadão devem ser riscadas das línguas modernas. (...) Não encaro como instituição pública esses estabelecimentos ridículos a que chamam colégios. ${ }^{18}$

Cumpre ressaltar que a educação sob o domínio do Ancien Régime era ministrada principalmente pela Igreja. Por outro lado, ao longo do período revolucionário, o debate político sobre os rumos da educação pública foi marcado pelo confronto entre projetos opostos.

Em outras palavras, ao passo que ao clero interessava a perpetuação do seu exclusivo domínio no âmbito educacional, os revolucionários inspirados pelos ideais e princípios iluministas buscavam promover um modelo de educação

\footnotetext{
${ }^{16}$ Idem, p. 88.

${ }^{17}$ GADOTTI, M. História das ideias pedagógicas. 6. ed. São Paulo: Ática, 1998, p. 88.

${ }^{18}$ ROUSSEAU, J.-J. Emílio ou da educação. 3. ed. Rio de Janeiro: Bertrand Brasil, 1995, p. 14.
} 
pública, universal, gratuita, igualitária, emancipadora e, sobretudo, laica. E é a partir principalmente das ideias rousseaunianas que estimula-se a substituição do controle eclesiástico da educação para a responsabilidade privativa do novo Estado fundado sobre bases democráticas e liberais. ${ }^{19}$

\section{2}

\section{O Direito à Educação Proveniente do Poder Constituinte}

É interessante o exame dos reflexos decorrentes da ebulição potente, dinâmica e sem precedentes ocasionada pela insurreição francesa ocorrida no século XVIII para a compreensão da concepção de poder constituinte. Além disso, a apreciação da essência, do caráter e dos propósitos do poder constituinte contribui para o entendimento dos possíveis vieses envolvidos no processo de consolidação dos direitos fundamentais que ele legitima e consagra. Evidentemente, tal análise é indispensável para a apreensão da conotação de direito fundamental à educação atribuída pelo poder constituinte brasileiro.

Portanto, inicialmente, é oportuno assinalar uma concepção de poder constituinte originário como aquele que "estabelece a Constituição de um novo Estado, organizando-o e criando os poderes destinados a reger os interesses de uma comunidade”. Inclusive, essa Constituição é considerada fruto do movimento revolucionário. ${ }^{20}$ Logo, o poder constituinte originário revolucionário pode ser compreendido como aquele que, por meio de uma insurreição, rompe com o poder constituinte já previamente constituído em um certo Estado soberano.

O poder constituinte é aquele responsável por elaborar o primeiro ou o novo conjunto de leis de certa comunidade (poder constituinte histórico), ou aquele que rompe com uma determinada ordem anterior para estabelecer uma completamente nova (poder constituinte revolucionário). Pois no caso de cisão com a realidade anterior com vistas ao estabelecimento de uma nova conjuntura sociopolítica, após os eventos de abrupta ruptura política ou social se geralmente se faz necessária a uma reforma ou renovação total do sistema normativo da nação.

Em resumo, o poder constituinte, na conjuntura do Estado Democrático de

\footnotetext{
${ }^{19}$ Op. Cit., p. 89.

${ }^{20}$ MORAES, A. Direito constitucional. 28. ed. São Paulo: Atlas, 2012, p. 25-26.
} 
Direito, pertence ao povo que tão somente o delega a um número de representantes que serão os encarregados de elaborar as normas que disciplinarão as relações humanas no novo cenário.

Preliminarmente, o diagnóstico do momento histórico que antecede e coincide com o período da Revolução Francesa, apresentado anteriormente, é essencial para a compreensão do processo de instituição e operação do poder constituinte. Inclusive, a transformação da Assembleia dos Estados Gerais em Assembleia Nacional Constituinte em decorrência do movimento revolucionário serve como modelo de titularidade legítima do exercício desse poder.

Além disso, o caráter emancipador dos ideais e princípios exaltados durante a Revolução Francesa e sua conexão com a concepção de poder constituinte com orientação progressista revelam-se pelo fato de que do final de 1789 a 1791, a Assembleia Nacional “Constituinte” elaborou a Constituição Francesa, cujo preâmbulo era a Declaração de 1789, que preconizava os novos valores de liberdade, igualdade e fraternidade. ${ }^{21}$

À luz dos eventos que deflagraram a profunda transição sociopolítica e institucional que a Revolução Francesa gerou, destaca-se a essência do poder constituinte. Como o representante da nação e a sua expressão imediata, ele é o produtor das leis fundamentais e forma a constituição política da nação. ${ }^{22}$

O que é, na perspectiva da ciência jurídica, o poder constituinte? É a fonte de produção das normas constitucionais, ou seja, o poder de fazer uma constituição e assim ditar as normas fundamentais que organizam os poderes do Estado. Em outros termos, é o poder de instaurar um novo ordenamento jurídico e, com isto, regular as relações jurídicas no seio de uma nova comunidade. ${ }^{23}$

Ademais, os fins do poder constituinte revelam-se na sua relação quase simbiótica com a Revolução, na qual ele representa uma categoria revolucionária no campo político e dispositivo de profunda mutação ou inovação política.

Deste ponto de vista, a relação entre revolução e direito, entre revolução e constituição, torna-se um continuum no qual o acréscimo racional é representado pela revolução. O direito e a constituição seguem o poder constituinte - é ele que dá racionalidade e forma ao direito. O poder constituinte manifesta-se como expansão revolucionária da capacidade humana de construir a história, como ato fundamental de inovação e, portanto, como procedimento absoluto.

\footnotetext{
${ }^{21}$ VOVELLE, M. Breve história da Revolução Francesa. 1. ed. Lisboa: Presença, 1985, p. 20.

${ }^{22}$ NEGRI, A. O poder constituinte: ensaio sobre as alternativas da modernidade. Rio de Janeiro: DP\&A, 2002, p. 311.

${ }^{23}$ Idem, p. 8.
} 
[...] A Declaração de Direitos de 1793 se identifica com este conceito quando considera os direitos dos cidadãos como ativos no esquema constitucional e identifica nesta atividade o motor da democracia social. ${ }^{24}$

Inclusive, a Revolução Francesa evidencia essa potência ou aptidão inerente ao poder constituinte de promover a inovação, instituindo uma nova ordem jurídica na inédita realidade sociopolítica. Essa "produtividade constitutiva da política” da Revolução, que necessitou “impor ex novo a concepção jusnaturalista contra um poder despótico” revela-se na Declaração de direitos. Assim, o poder constituinte se impõe como "ato de fundação constitucional de uma nova sociedade”, incorporando-se "à história da classe operária e constitui ainda hoje a principal base do ordenamento jurídico do Estado social”. ${ }^{25}$

Portanto, pode-se concluir que o poder constituinte consiste em um legado político e jurídico produto das insurreições. A história da Revolução Francesa evidencia que há uma íntima relação de interdependência entre o movimento revolucionário e o surgimento do poder constituinte.

Após 1789, revolução e poder constituinte entram na grande cena da história e do pensamento moderno como características indissolúveis da atividade humana transformadora. Quando se fala em revolução, fala-se em poder constituinte: figuras de rebelião, de resistência, de transformação, de criação, de construção do tempo (acelerado, programado, distendido...) e da lei aglomeram-se nesta síntese. A revolução é necessária: assim como são necessidades humanas viver moralmente, constituir-se eticamente, liberar o corpo e a mente da escravidão. E o poder constituinte é o meio para atingir esta finalidade. ${ }^{26}$

Indubitavelmente, pode-se constatar claramente que o tempo do processo revolucionário francês marcado por sua trama de "necessidades e utopias, interesses e discursos, vontade de potência e dinâmica política”27 reflete-se na configuração contemporânea do poder constituinte, que evidencia os efeitos produzidos pelos embates, confrontos e tensões entre correntes políticas opostas.

Considerada a "expressão radical do poder constituinte democrático”28, a Revolução Francesa evidencia a relevância da soberania popular no processo de construção de uma nova ordem política, uma vez que a Constituição deveria ser a expressão da vontade das classes populares.

\footnotetext{
${ }^{24}$ Idem, p. 40.

${ }^{25}$ NEGRI, A. O poder constituinte: ensaio sobre as alternativas da modernidade. Rio de Janeiro: DP\&A, 2002, p. 33.

${ }^{26}$ Idem, p. 39-40.

${ }^{27}$ Idem, p. 278-279.

${ }^{28}$ Idem, p. 281.
} 
Inclusive, nota-se na primeira fase da Revolução, a reconquista do espaço público por parte da multidão, mediante a manifestação de uma potência que evolui ao longo do ciclo revolucionário, culmina com a expressão da unidade de projeto das massas rumo a uma democracia cada vez mais intensa, cuja voragem é o poder constituinte.

Assim, esse movimento revolucionário, sob o protagonismo da burguesia e do proletariado como os novos sujeitos políticos da luta de classes, revela-se uma trajetória marcada por sua temporalidade peculiar rumo à concretização do projeto democrático de liberação política e social.

Contudo, como contraponto à apologia da utopia democrática revolucionária, torna-se oportuno realçar o alerta de Benjamin Constant aos representados pelo poder constituinte. Se o sistema representativo é uma procuração dada pelos cidadãos para “ter seus interesses defendidos” na busca da liberdade e da igualdade, eles devem "exercer uma vigilância ativa e constante sobre seus representantes e reservar-se o direito de, em momentos que não sejam demasiado distanciados, afastá-los, caso tenham traído suas promessas, assim como o de revogar os poderes dos quais eles tenham eventualmente abusado”. ${ }^{29}$

Não obstante, apesar dos potenciais limites ou riscos degenerativos herdados do modelo representativo revolucionário francês, a realidade constitucional contemporânea pode se beneficiar com o legado desse democrático sistema de representação política fundamentado na igualdade entre os cidadãos.

Inclusive, é válido salientar que, em virtude do rompimento revolucionário com o regime monárquico absolutista suscitado pelo espírito iluminista, a Constituição promulgada em 1791 já preconizava uma concepção de educação pública igualitária e comum a todos os cidadãos.

Assim, em 10 de setembro de 1791 um relatório inspirado em concepções enciclopedistas foi apresentado por Talleyrand à Assembleia Nacional Legislativa, porém não foi votado devido a limitações de tempo. Então, regressou ao parlamento para continuidade do processo de discussão no âmbito do Comitê de Instrução Pública presidido pelo Marquês de Condorcet. Partidário da linha de

\footnotetext{
${ }^{29}$ CONSTANT, B. Da liberdade dos antigos comparada à dos modernos (1819). In: MORAES,
} João Quartim (Org.) Revista Filosofia Política. Porto Alegre: L\&PM, 1985, p. 23. 
pensamento enciclopedista proposta por Diderot, Condorcet opunha-se ao despotismo, ao dogmatismo e à escravidão. Defendendo a igualdade e os valores republicanos, ele confiava que o progresso da ciência e da razão geraria o contínuo aperfeiçoamento da sociedade e a felicidade dos indivíduos.

Então, em 5 de março de 1792, Condorcet tornou-se relator do projeto de decreto sobre a organização geral da educação pública apresentado à Assembleia Nacional em 20 e 21 de abril de 1792. Com fundamentos teóricos oriundos das "Cinq mémoires sur l'instruction publique" publicadas por ele em 1791, esse projeto caracterizava-se pela garantia do direito à educação em condições de igualdade para ambos os sexos e consolidava a proposta de um ensino público universal, gratuito e unificado, com caráter inexoravelmente laico. ${ }^{30}$ A educação, como uma questão política, deveria contribuir para a liberdade de pensamento, a emancipação, a autonomia do cidadão aprendiz e o desenvolvimento dos talentos de todos sem qualquer tipo de discriminação.

O projeto de Condorcet foi o precursor de planos posteriores de organização da educação pública que visavam formar o cidadão como um "homem novo" para dar prosseguimento à Revolução. Considerando a educação como um dos instrumentos prioritários na construção da nação, concebia-se uma pátria reestruturada marcada pela igualdade de oportunidades, com vistas à efetivação dos princípios estruturantes de uma sociedade democrática. Assim, reconhecendo que as reformas educacionais precisam seguir as transformações políticas ocorridas ao longo do período revolucionário, Condorcet "propôs o ensino universal como meio para eliminar a desigualdade”. ${ }^{31}$

Cumpre assinalar também o "Plano Nacional de Educação" da autoria de Lepelletier (1760-1793) aprovado pela Assembleia Nacional Constituinte em 1793, mas que nem chegou a ser posto em prática. Com inspirações em Rousseau, o teor do supramencionado plano "sintetiza as aspirações frustradas de unidade entre a educação e a política e de defesa do ensino público, gratuito, obrigatório e igual para todos”. O texto sustentava o princípio da igualdade efetiva, o direito de todo cidadão ao saber e a educação das crianças em acampamentos a cargo do

\footnotetext{
${ }^{30}$ PIOZZI, P. Utopias revolucionárias e educação pública: rumos para uma nova "cidade ética”. Educ. Soc., Campinas, vol. 28, n. 100. Out. 2007, p. 720.

${ }^{31}$ GADOTTI, M. História das ideias pedagógicas. 6. ed. São Paulo: Ática, 1998, p. 89.
} 
Estado. Partindo-se do pressuposto rousseauniano de que se o homem é naturalmente bom, não há necessidade de religião. ${ }^{32}$

Além disso, evidenciando a ênfase educacional revolucionária, ressalte-se que o artigo 22 da Declaração dos Direitos do Homem e do Cidadão de 1793 também preconizava uma concepção de educação como uma necessidade de todos, devendo a sociedade incentivar, com todo o seu poder, o progresso da razão pública ao colocar a educação ao alcance de todos os cidadãos.

Portanto, considerando a escola como um dos instrumentos ensejadores da regeneração da sociedade mediante a extensão das oportunidades de acesso ao conhecimento e, consequentemente, à cidadania plena, busca-se no conturbado contexto da França revolucionária a gênese da ênfase na faceta redentora da educação. A investigação que objetiva encontrar eventos e atos fundadores da acepção de escola pública, universal, gratuita, laica e igualitária avança pelo rico pano de fundo histórico e sociopolítico que somente a Revolução Francesa dispôs.

O discurso sobre o valor da educação no processo de criação de uma nova ordem social igualitária, democrática e liberal pode ser melhor percebido sobretudo no curto mas fértil período marcado pelo predomínio jacobino que, entre outras coisas, rompeu com as concepções educacionais anacrônicas, dualistas e, portanto, injustas.

Neste sentido, é pertinente a contribuição de Carlota Boto, que denuncia a realidade de promessas democráticas realizadas com origem e base no discurso liberal revolucionário francês e que ainda não foram cumpridas no Brasil. Em outras palavras, o clima liberal francês do século XVIII, tal como uma herança, repercutiu no discurso republicano brasileiro. Deste modo, parece ser possível delinear os contornos do discurso educacional proferido ao longo do movimento revolucionário na França em consonância com o pensamento pedagógico iluminista que pressupunha um "potencial transformador contido no ato de educar."33

O século XVIII, na França, deslocaria o problema do ensino proporcionando-lhe, inclusive uma primazia teórica que até então inexistia. Do Iluminismo à Revolução, vislumbra-se o surgimento de um espírito público no qual a pedagogia

\footnotetext{
${ }^{32}$ Idem, p. 101.

${ }^{33}$ BOTO, Carlota. A escola do homem novo: entre o Iluminismo e a Revolução Francesa. São Paulo: UNESP, 1996, p. 21-23.
} 
passa a ser a pedra de toque. [...] A cidadania, no entanto, exigia emancipação pelas Luzes, pela erradicação do suposto obscurantismo. Reivindicar uma escola única, laica e gratuita, universalizada para todas as crianças de ambos os sexos, significava conferir legitimidade ao prospecto de regeneração e de emancipação inscrito naquele período que presenciava o acelerar da história. ${ }^{34}$

Assim, embora “tributários do ideário democrático da Revolução que consolida a política burguesa" 35 , raramente os brasileiros têm testemunhado as promessas liberais de emancipação humana traduzidas em políticas públicas educacionais relevantes e dotadas de efetividade social.

\section{3}

\section{A Educação no Contexto da Transição da Democracia para a Ditadura Revolucionária Francesa}

A partir de uma análise comparativa entre a primeira Declaração (“Déclaration des Droits de l'Homme et du Citoyen”) de 26 de agosto de 1789, a segunda Declaração de 24 de junho de 1793 e a Declaração dos Direitos e dos Deveres do Homem e do Cidadão ("Déclaration des Droits et Devoirs de L'Homme et du Citoyen”, Preâmbulo da Constituição do Ano III de 22 de agosto de 1795), constata-se que, respectivamente, cada um desses documentos possui uma ênfase própria e particular que reflete o espírito social e político do específico período histórico em que foi promulgado ao longo do ciclo revolucionário.

Inclusive, considera-se que "há não uma, mas várias declarações e uma série de projetos que, longe de encontrarem conclusão na Declaração de 1789, permanecem e fazem sentir a presença de uma árdua luta em curso até as Declarações de 1793 e de 1795, a dos jacobinos e a do Termidor [...]”. ${ }^{36}$

Portanto, o teor da primeira declaração, que instituía os princípios basilares da nova ordem social decorrente da Revolução, evidencia a unidade de propósito de todos os setores democráticos da nação que, então, em comunhão, afirmavam possuir um só ardor revolucionário de tal modo

[...] que todo o terceiro-estado - isto é, tanto o povo como a burguesia que o conduzia - estava unido nesta fase e tinha objetivos comuns. A burguesia era um

\footnotetext{
${ }^{34}$ Idem, p. 16.

${ }^{35}$ Idem, p. 16.

${ }^{36}$ NEGRI, A. O poder constituinte: ensaio sobre as alternativas da modernidade. Rio de Janeiro: DP\&A, 2002, p. 282.
} 
elemento jovem e progressista apostado em combater o absolutismo feudal. Não receava ainda o povo e marchava para a frente ombro a ombro com ele. ${ }^{37}$

Quanto ao estabelecimento de direitos e garantias individuais, essa declaração "por seu caráter universal, é um passo significativo no processo de transformar o homem comum em cidadão, cujos direitos civis lhe são garantidos por lei”38. O documento estabelece a liberdade e a igualdade de direitos entre os homens que, a partir de então, se tornam intrinsecamente cidadãos e cujos direitos naturais e imprescritíveis merecem defesa e conservação. Inclusive, há menção aos direitos da Nação, que devem estar "sempre subordinados aos direitos do cidadão, visto que o Estado não é um fim em si mesmo; seu objetivo maior é assegurar que os direitos civis sejam usufruídos pelo cidadão. Quando o Estado falhar nessa sua principal missão, ao cidadão resta o direito de sublevação.»39

Contudo, apesar dessa declaração conter artigos que proclamavam a liberdade e, principalmente, a igualdade de direitos de uma forma extraordinariamente inusitada e sem precedentes em um contexto histórico no qual a servidão e a escravidão eram práticas corriqueiras e habituais, ela não ficou imune a críticas. Pois, ao passo em que instituía a inalienabilidade de direitos tais como a liberdade pessoal, a inviolabilidade pessoal e o direito de resistência à opressão, a proclamação do direito inalienável à propriedade privada evidenciava as deficiências burguesas do supracitado diploma legal revolucionário. Assim, vale ressaltar que este "fato aponta para as limitações burguesas da declaração, pois significava que a liberdade que proclamava era de tipo puramente formal, porque perpetuava a desigualdade baseada na propriedade. ${ }^{40}$

No entanto, os frutos da vitória não pertenciam nem a todo o terceiro-estado nem mesmo a toda a burguesia. Em pouco tempo o poder ia ter praticamente às mãos da grande burguesia ou da "aristocracia burguesa" como veio a ser chamada. $\mathrm{Na}$ Assembléia Constituinte, nas câmaras de Paris e das cidades de província e na Guarda Nacional, a voz decisiva em breve seria a da mais rica e economicamente mais poderosa facção da burguesia. ${ }^{41}$

\footnotetext{
${ }^{37}$ MANFRED, A. Z. A concepção materialista da Revolução Francesa. São Paulo: Global, 1982, p. 20

${ }^{38}$ ODALIA, N. A liberdade como meta coletiva. In: PINSKY, J; PINSKY, C. B. (Org.). História da cidadania. 4. ed. São Paulo: Contexto, 2008, p. 166.

${ }^{39}$ ODALIA, N. A liberdade como meta coletiva. In: PINSKY, J; PINSKY, C. B. (Org.). História da cidadania. 4. ed. São Paulo: Contexto, 2008, p. 167.

${ }^{40}$ MANFRED, A. Z. A concepção materialista da Revolução Francesa. São Paulo: Global, 1982, p. 20-21.

${ }^{41}$ Idem, p. 21.
} 
Muito embora o art. $1^{\circ}$ da Declaração de 1789 tenha consagrado o princípio da isonomia jurídico-formal objetivando eliminar privilégios, distinções, isenções pessoais e regalias nobiliárquicas, essa modalidade de igualdade perante a lei ocasionou o surgimento de novas desigualdades socioeconômicas de fato entre os homens. Contudo, estas discrepâncias eram tão desumanas quanto aquelas típicas da sociedade dominada pelo Ancien Régime.

No que tange à problemática da isonomia formal geradora de desigualdades econômicas, vale assinalar que José Afonso da Silva, ao considerar o contexto brasileiro como exemplo, enfatiza que

Nossas constituições, desde o Império inscreveram o princípio da igualdade, como igualdade perante a lei, enunciado que, na sua literalidade, se confunde com a mera isonomia formal, no sentido de que a lei e sua aplicação tratam a todos igualmente, sem levar em conta as distinções de grupos. ${ }^{42}$

Segundo Silva ${ }^{43}$, a Constituição de 1988 busca promover uma aproximação entre as duas espécies de isonomia, pois não se restringe ao mero enunciado da igualdade perante a lei, mas consigna também a igualdade entre homens e mulheres, proibindo diferenciações e discriminação de qualquer tipo.

Nesse mesmo diapasão, a lição sobre igualdade no discurso de Rui Barbosa na formatura da turma de 1920 da Faculdade de Direito de São Paulo inclui uma paráfrase da máxima aristotélica de que a igualdade equivale a tratar igualmente os iguais e desigualmente os desiguais, na medida de sua desigualdade.

A regra da igualdade não consiste senão em quinhoar desigualmente aos desiguais, na medida em que se desigualam. Nesta desigualdade social, proporcionada à desigualdade natural, é que se acha a verdadeira lei da igualdade. $\mathrm{O}$ mais são desvarios da inveja, do orgulho, ou da loucura. Tratar com desigualdade a iguais, ou a desiguais com igualdade, seria desigualdade flagrante, e não igualdade real. Os apetites humanos conceberam inverter a norma universal da criação, pretendendo, não dar a cada um, na razão do que vale, mas atribuir o mesmo a todos, como se todos se equivalessem. ${ }^{44}$

Barbosa reputou aquela concepção de igualdade como um insulto contra a razão, a fé, a civilização e a humanidade, além de responsável pela miséria. Contudo, afirmou que, embora não possa igualar aqueles que a natureza criou

\footnotetext{
${ }^{42}$ SILVA, J. A. Curso de direito constitucional positivo. 24. ed. São Paulo: Malheiros, 2005, p. 214.

${ }^{43}$ SILVA, J. A. Curso de direito constitucional positivo. 24. ed. São Paulo: Malheiros, 2005, p. 215.

${ }^{44}$ BARBOSA, R. Oração aos moços. 5. ed. Rio de Janeiro: Fundação Casa de Rui Barbosa, 1997, p. 26.
} 
desiguais, a sociedade pode compensar as desigualdades originais através da educação e do trabalho. Ele ainda procura levar a juventude a refletir sobre a legitimidade da lei produzida segundo as conveniências das minorias oligárquicas.

Ora, senhores bacharelandos, pesai bem que vos ides consagrar à lei, num país onde a lei absolutamente não exprime o consentimento da maioria, onde são as minorias, as oligarquias mais acanhadas, mais impopulares e menos respeitáveis, as que põem, e dispõem, as que mandam, e desmandam em tudo; a saber: num país, onde, verdadeiramente, não há lei, não o há, moral, política ou juridicamente falando. ${ }^{45}$

Contudo, no que tange à ênfase da segunda Declaração, seu texto ecoa o repúdio dos Jacobinos à "natureza interesseira e antidemocrática da política seguida pelo partido da alta burguesia na Assembléia e apontaram as conseqüências, que seriam fatais para a revolução." ${ }^{46}$ A razão disso reside no fato de que, inicialmente, os Girondinos eram opositores do absolutismo feudal. Porém, uma vez no poder devido à "bem-sucedida revolta popular na qual verdadeiramente não tinham tomado parte, partiram do princípio de que os principais objetivos da revolução já tinham sido realizados e tornaram-se uma força conservadora."47

A indiferença girondina em relação às condições indignas em que vivia a maioria do povo, sua defesa dos privilégios à alta burguesia e a sua dissimulada e secreta proteção à realeza ensejou uma guinada jacobina radical e violenta em direção à instituição da República evidenciada no conteúdo do texto da Declaração de 1793. Inclusive, vale ressaltar, a partir de um exame comparativo,

[...] duas diferenças importantes em relação à primeira Declaração. Em primeiro lugar, a liberdade deixa de ser definida como direito e passa a ser definida como poder. Isto implica que a liberdade deixa de ser pensada como uma faculdade e, mais, deixa de ser pensada como uma faculdade concedida pelo Estado aos homens. Em segundo lugar, e talvez mais importante, a lei deixa de ser um limite à liberdade, passando a ser apenas instrumento de sua salvaguarda. ${ }^{48}$

Além de enfatizar a temporalidade da Revolução Francesa como movimento de libertação operária, Negri ainda ressalta que a Declaração de 1793 “reconhece o direito à insurreição como conseqüência extrema do caráter inalienável da

\footnotetext{
${ }^{45}$ Idem, p. 35-36.

${ }^{46}$ MANFRED, A. Z. A concepção materialista da Revolução Francesa. São Paulo: Global, 1982, p. 24.

${ }^{47}$ MANFRED, A. Z. A concepção materialista da Revolução Francesa. São Paulo: Global, 1982, p. 29.

${ }^{48}$ POGREBINSCHI, T. Emancipação política, direito de resistência e direitos humanos em

Robespierre e Marx. Dados [online]. 2003, vol. 46, n.1, p. 137.
} 
soberania popular: um direito público subjetivo que os homens do povo tomam ao pé da letra, como indivíduos e com massa.”49

Ademais, em sua proclamação de direitos, a Declaração jacobina, além de ignorar os limites da sua antecessora, no que se refere ao exercício da resistência, ainda emprega termos como natureza, existência, fraternidade, universo, direito natural, progresso, entre outros, buscando garantir direitos para todos os cidadãos. Inclusive, ressalte-se as conquistas sociais e democráticas do regime jacobino:

Num período extremamente curto a ditadura jacobina conseguiu alcançar os principais objetivos da revolução: os padrões sociais feudais haviam sido abolidos; a contra-revolução na pátria tinha sido repelida para lá das fronteiras da República. Os Jacobinos puderam realizá-lo porque o povo estava unido atrás deles e porque na sua política eles defenderam os interesses dos pobres das cidades e das massas populares.

Enquanto ainda existia uma real ameaça de restauração da ordem prérevolucionária pela mão dos intervencionistas estrangeiros, a burguesia e as camadas proprietárias da população rural e urbana estavam todas preparadas para aceitar as rigorosas restrições da ditadura jacobina, os preços fixos, as penalidades impostas por especulação ou por exigência da prestação de serviços. ${ }^{50}$

Entretanto, na reação ao terror contrarrevolucionário que assassinou líderes como Marat e Chalier, o forte e centralizado regime jacobino afastou-se gradativamente da democracia, intensificando o terror ao passar a encarcerar e executar na guilhotina meros suspeitos, além de mobilizar um enorme exército popular para lutar contra a coalizão intervencionista estrangeira. ${ }^{51}$

Por outro lado, a terceira Declaração, por sua vez, repercute a tônica da contrarrevolução burguesa que teve início com a derrubada do governo jacobino em 9 do Termidor de 1794.

A Declaração de 1795 aniquila, portanto, não apenas todas as considerações de Robespierre a respeito do direito de resistência à opressão, como também deixa de incorporar todos os artigos que as Declarações de 1789 e 1793 continham sobre ele. Em perspectiva diametralmente oposta, a Declaração de 1795 parece refletir com exclusividade uma preocupação básica do contratualismo do século XVII, qual seja, a de fundamentar a obrigação política. Sai de cena, no texto da Declaração, a resistência (ou desobrigação), e entra a obrigação. Se hoje em dia podemos lamentar o fato de a Declaração jacobina não ter sido a definitiva, por

\footnotetext{
${ }^{49}$ NEGRI, A. O poder constituinte: ensaio sobre as alternativas da modernidade. Rio de Janeiro: DP\&A, 2002, p. 282.

${ }^{50}$ Op. Cit, p. 38.

${ }^{51}$ MANFRED, A. Z. A concepção materialista da Revolução Francesa. São Paulo: Global, 1982, p. 35-36.
} 
outro lado, podemos também abençoar o fato de não ter sido a Declaração thermidorana a ter permanecido. ${ }^{52}$

Assim, os “Termidorianos de Direita”, prósperos especuladores que lucraram com a liberalização preços que agravou ainda mais a fome dos mais pobres, passaram a dominar na Convenção e no governo retaliando com terror contra os jacobinos e anulando suas realizações sociais e democráticas. Consequentemente, promulgou-se uma constituição marcada pela eliminação do sufrágio universal e pelo retorno do voto censitário. ${ }^{53}$

A ferocidade dos termidorianos manifesta na Declaração de 1795, uma completa inversão da tônica da doutrina revolucionária presente na Declaração de 1793, negava a criatividade das massas e esperava sua obediência. Desfigurando o discurso sobre o poder constituinte em decreto sobre os “deveres” dos cidadãos, paradoxalmente tal desnaturação reacionária suscitava horror. ${ }^{54}$

O regime do Diretório, instituído a partir do final de 1795, consistiu no domínio da nova burguesia especulativa, que executava uma política reacionária e antipopular em função do desprezo e temor em relação aos menos favorecidos. Entretanto, esta mesma burguesia que tinha se assenhorado das riquezas da antiga nobreza, constitui-se como um regime antimonárquico que aniquilava brutalmente as tentativas realistas de restaurar o poder do Ancien Régime.

A “Conspiração dos Iguais”, um movimento de tendências igualitárias ocorrido em 1796 e considerado como um protocomunismo ou precursor embrionário da ideologia comunista liderado por Gracchus Babeuf, o primeiro revolucionário comunista, que apregoou no "Manifesto dos Iguais" a abolição das “distinções de classes entre ricos e pobres, entre grandes e pequenos, entre senhores e servos, entre governantes e governados." 55

Baseando-se em princípios de propriedade comum, democracia direta e fraternidade igualitária, Gracchus Babeuf dedicou-se à conversão da igualdade

\footnotetext{
${ }^{52}$ POGREBINSCHI, T. Emancipação política, direito de resistência e direitos humanos em Robespierre e Marx. Dados [online]. 2003, vol. 46, n.1, p. 141-142.

${ }^{53}$ Op. Cit., p. 43-44.

${ }^{54}$ NEGRI, A. O poder constituinte: ensaio sobre as alternativas da modernidade. Rio de Janeiro: DP\&A, 2002, p. 302.

${ }^{55}$ BABEUF, G. O manifesto dos iguais. Disponível em: $<$ https://www.marxists.org/portugues/babeuf/1796/mes/manifesto.htm>. Acesso em: 2 nov. 2013.
} 
formal perante a lei na igualdade real entre todos os cidadãos, o que conjugaria os três princípios tão propalados durante a Revolução Francesa.

Tal igualdade perfeita e de fato implicaria no "estabelecimento da administração popular, pela supressão da propriedade privada, pela vinculação de cada indivíduo ao seu talento, fazendo-o depositar os frutos do seu trabalho em um espaço coletivo, estabelecendo uma administração única dos bens que assegurará a sua repartição segundo a mais escrupulosa igualdade.»56

Neste mesmo diapasão, é válido assinalar ainda que o espírito da época da promulgação da Declaração de 1795 e o seu teor propriamente dito, foram ambos marcados por uma guinada conservadora e repressiva por parte do regime contrarrevolucionário. O Diretório continuava a promover mudanças favoráveis à consolidação do projeto político burguês.

Vale assinalar que elas estão intimamente relacionadas à perspectiva da educação tanto como um Aparelho Ideológico do Estado à luz da teoria de Louis Althusser, quanto do Poder Disciplinar como exposto por Michel Foucault. Em tempo: esses conceitos serão apresentados com maiores detalhes posteriormente no capítulo subsequente.

\footnotetext{
${ }^{56}$ BABEUF Apud CATTANI, A. D. Libertários e tutelares no mundo do trabalho. Tempo Social; Rev. Sociol. USP: São Paulo, 14(2): 71-81. Out. 2002, p. 75.
} 


\section{2 \\ A Educação como Locus de Disputa Ideológica no Contexto do Estado Capitalista}

\section{1}

\section{A Educação como Instrumento de Dominação Burguesa}

Conforme já exposto, embora inicialmente impulsionada por ideais democráticos, liberais e emancipatórios incluídos nas duas primeiras declarações de direitos, a Revolução Francesa experimentou uma guinada reacionária sob o domínio da burguesia antidemocrática. Isto é, a princípio revolucionária, a burguesia tornou-se, em seguida, conservadora e, por fim, contrarrevolucionária. Consequentemente, a original visão progressista de educação igualitária e libertadora dos revolucionários não ficou ilesa a essa reviravolta ideológica.

Com efeito, tal cenário repressivo confirma a tese de Marx de que a ordem social e a educação estão estruturadas a serviço dos interesses da classe burguesa e "não refletem as necessidades objetivas da população; quando muito, refletem os interesses dos opressores." ${ }^{57}$ As classes dirigentes perpetuam a segregação, monopolizando e moldando o sistema educacional a seu bel-prazer. Assim, a educação burguesa maneja o espoliado proletariado alienando-o ao longo do processo produtivo, o que culmina na degradação das futuras gerações obreiras. O saber "pertence ao capital, e ele explora-o a fundo" condenando "a maior parte da humanidade a ser escrava, puro instrumento de trabalho"58.

O caráter excludente e elitista da educação capitalista pode ser constatado na história das civilizações da Antiguidade. Apenas as elites possuíam uma instituição específica para o cuidado e a educação dos jovens. A escola, como local específico para o ensino, surge nas cortes dos primeiros estados históricos da Mesopotâmia e do vale do Nilo e se espalha pelas ilhas do Mediterrâneo, Grécia e Roma. ${ }^{59}$ Inicialmente, a escola era uma instituição concebida exclusivamente para a formação das classes hegemônicas, em uma separação antagônica entre “a

\footnotetext{
${ }^{57}$ SCURO NETO, P. Manual de sociologia geral e jurídica: lógica e método do direito, problemas sociais, comportamento criminoso, controle social. 4. ed. São Paulo: Saraiva, 2000, p. 140.

${ }^{58}$ MARX, K.; ENGELS, F. Crítica da educação e do ensino. Lisboa: Moraes, 1978, p. 158.

${ }^{59}$ MANACORDA, M. A. Marx e a pedagogia moderna. São Paulo: Cortez, 1991, p. 116.
} 
riqueza que não trabalha e a pobreza que trabalha para viver” e que se caracteriza por "reproduzir num pólo a miséria e no outro a riqueza, produz forçosamente também, dum lado, a civilização e, do outro, a bestialidade”. ${ }^{60}$ As primeiras “escolas públicas”, voltadas exclusivamente para a formação das classes dirigentes, surgiram da educação transmitida por mestres especialistas no seio das famílias ilustres. Destinavam-se ao preparo dos futuros "pensadores de classe", “ideólogos ativos”, sacerdotes ou cidadãos-guerreiros, que se aperfeiçoavam para exercer o poder político e a arte militar. ${ }^{61}$

Já os filhos das classes subalternas, sem um local de instrução específico, qualificavam-se para o trabalho, principalmente manual, sempre na prática e em contato permanente com mestres artífices, onde o ensinamento era parte intrínseca do processo de produção. Assim, durante muito tempo, "na sociedade dividida em classes pela divisão do trabalho”, e de diferentes métodos de formação humana, não se podia esperar o desenvolvimento igualitário e democrático dos aprendizes de classes sociais distintas. ${ }^{62}$ Nesse cenário sombrio de exclusão e privilégios, o proletariado lutava pelo direito de desfrutar de escolas estabelecidas para seus filhos em locais onde elas eram inexistentes ou que possuíam meramente fins religiosos. ${ }^{63}$ Os ideais de educação pública, universal, laica e gratuita surgem com a finalidade de transformar os ignorantes e explorados vassalos do Antigo Regime em cidadãos instruídos e conscientes dos seus direitos. ${ }^{64}$

Em seguida, a consolidação da supremacia burguesa e a decorrente estruturação do sistema educacional passaram a evidenciar uma "natural" dualidade do amestramento disciplinador para a prole dos operários alienados e a educação formativa de qualidade para os herdeiros das classes dominantes predestinados ao governo. Isto é, a notória distinção entre a capacitação dos futuros dirigentes e o adestramento profissional das classes subalternas exemplifica esse dualismo educacional típico do modo capitalista de produção.

[...] na sociedade dividida em classes, [...] o ensino e o trabalho aparecem também divididos, dois termos até antagônicos. A "escola" [...] enquanto estrutura específica de formação de um determinado tipo de homem "dividido", nasce

\footnotetext{
${ }^{60}$ MARX, K.; ENGELS, F. Crítica da educação e do ensino. Lisboa: Moraes, 1978, p. 11.

${ }^{61}$ MANACORDA, M. A. Marx e a pedagogia moderna. São Paulo: Cortez, 1991, p. 117.

${ }^{62}$ Idem, p. 118-120.

${ }^{63}$ Idem, p. 71.

${ }^{64}$ SAVIANI, D. Escola e democracia: teorias da educação, curvatura da vara, onze teses sobre a educação política. 34. ed. Campinas: Autores Associados, 2001, p. 6.
} 
historicamente no interior das classes possuidoras, como estrutura destinada exclusivamente à sua formação; não existe para as demais classes. Apenas as classes possuidoras têm essa instituição específica que chamamos escola e que [...] apenas há pouco tempo, ou seja, aproximadamente a partir do início da revolução industrial, começa a tornar-se, em perspectiva, uma coisa de toda a sociedade. Tem-se falado, e ainda se fala a toda hora, da oposição entre a escola do trabalho e a escola do doutor, entre escola desinteressada e escola profissional [... $]^{65}$

Deste modo, conclui-se que a unidade da educação não passa de uma ilusão ideológica que, ocultando sua segmentação, traça percursos distintos segundo a origem e a destinação sociopolítica dos cidadãos. Todavia, o sistema escolar, no que tange aos conteúdos, métodos de ensino e critérios de avaliação, deve tratar os alunos oriundos das diferentes camadas sociais como iguais em direitos e deveres, independentemente das desigualdades socioculturais existentes entre eles. ${ }^{66}$

Além disso, historicamente, as classes hegemônicas têm fomentado a instrução dos operários apenas para habilitá-los técnica, social e ideologicamente para o trabalho, subjugando controladamente o papel social da educação para atender às exigências imediatas da produção capitalista. Cuidando para que o ensino reproduza exclusivamente as condições de saber e ignorância imprescindíveis à acumulação do capital, a universalidade da educação interessa às classes dominantes, pois possibilita formar operários com conhecimentos elementares que contribuem para a ampliação do lucro da burguesia industrial.

Assim, no contexto de supremacia burguesa, o controlado sistema educacional exerce a função de reprodutor da sociedade de classes, ratificando o modelo capitalista. Esse domínio ideológico ocasiona uma cruel e insidiosa expropriação da humanização dos operários mediante a manipulação da educação, que provoca uma atrofia moral e prejuízo intelectual nas classes subalternas.

Historicamente, a educação, produto e produtora das relações sociais sujeitas aos interesses antagônicos de classe, tem se revelado uma arena de disputa hegemônica em relação à articulação das concepções, da organização dos sistemas e da configuração dos processos e conteúdos educacionais. Portanto, há "relações entre a estrutura econômico-social, o processo de produção, as

\footnotetext{
${ }^{65}$ MARX, K.; ENGELS, F. Crítica da educação e do ensino. Lisboa: Moraes, 1978, p. 72.

${ }^{66}$ BOURDIEU, P. A escola conservadora: as desigualdades frente à escola e à cultura. In: NOGUEIRA, M. A; ATANI, A. (Orgs.). Escritos de educação: 5. ed. Rio de Janeiro: Vozes, 2003, p. 53.
} 
mudanças tecnológicas, o processo e divisão do trabalho, produção e reprodução da força de trabalho e os processos educativos ou de formação humana.”67

Uma sociedade caracterizada por autoritarismo, rigidez socioeconômica e ausência de "mobilidade vertical ascendente", é semelhante ao sistema de castas do Hinduísmo, no qual o grupo social é hereditariamente determinado. Essa condição foi denunciada por Paulo Freire, pois também "se caracteriza pela conservação do status ou privilégio e por desenvolver todo um sistema educacional para manter este status” ${ }^{\text {. }}$.

Nestas sociedades se instala uma elite que governa conforme as ordens da sociedade diretriz. Esta elite impõe-se às massas populares. Esta imposição faz com que ela esteja sobre o provo e não com o povo. As elites prescrevem determinações às massas. Estas estão sob o processo histórico. Sua participação na história é indireta. Não deixam marcas como sujeitos, mas como objetos. ${ }^{69}$

Ao longo de cada época, as ideias dominantes têm expressado os pensamentos da classe dirigente, que possui os meios de produção material e, simultaneamente, dispõe dos meios de produção intelectual. Evidentemente, uma vez que esses ideais dominantes refletem as relações materiais hegemônicas, "é preciso desconfiar ao máximo das ideias destiladas pelo Estado das classes dominantes, ou seja, pela educação nacional."70

Como exemplo disso, a ideologia pedagógica hegemônica da burguesia industrial manifesta no programa da Confederação Nacional da Indústria (CNI) remete à "concepção gramsciana de hegemonia: a capacidade de um grupo social de exercer a direção político-cultural do conjunto da sociedade”. ${ }^{71}$ Suas ações políticas para instituir organismos de defesa de seus interesses geraram “a montagem do megaaparelho de (con)formação da classe trabalhadora às necessidades econômico-políticas do projeto burguês de sociedade urbanoindustrial - o Sistema CNI”. ${ }^{72}$

Apesar de apregoar ideais democráticos, o atual sistema escolar é injusto, pois perpetua as desigualdades sociais e preserva privilégios. Por meio desse

\footnotetext{
${ }^{67}$ FRIGOTTO, G. Educação e a crise do capitalismo real. 5. ed. São Paulo: Cortez, 2003, p. 26.

${ }^{68}$ FREIRE, P. Educação e mudança. Rio de Janeiro: Paz e Terra, 1979, p. 34.

${ }^{69}$ Idem, p. 34.

${ }^{70}$ BUFFA, E. Educação e cidadania burguesas. In: BUFFA, E; ARROYO, M. G.; NOSELLA, P. (Orgs.). Educação e cidadania: quem educa o cidadão? 13. ed. São Paulo: Cortez, 2007, p. 24.

${ }^{71}$ RODRIGUES, J. O moderno príncipe industrial: o pensamento pedagógico da Confederação Nacional da Indústria. Campinas: Autores Associados, 1998, p. 8.

${ }^{72}$ Idem, p. 41.
} 
processo de violência simbólica, que privilegia os valores hegemônicos da burguesia perpetuadores das desigualdades sociais, a classe dominante se impõe, pois a escola deixa de promover a transformação social e a igualdade.

\section{2 \\ A Educação para Reintegração da Onilateralidade e Emancipação Humana à Luz do Materialismo Histórico}

Ao afastar a ciência do trabalho, o Capitalismo a transforma em uma "força alienada, um poder exterior a ele, que o domina e que, por isso, contribui para a sua desumanização."73 Como resultado, forma-se um "homem parcial, apropriado e anexado pela vida a uma função unilateral, aviltado, mutilado, aleijado, tornado uma monstruosidade, ser incapaz de fazer algo de independente, intelectual e fisicamente reduzido a trapos". ${ }^{74}$ Inclusive, vale ressaltar a influência do ensino religioso nesse processo de formação unilateral do proletariado.

A divisão do trabalho condiciona a divisão da sociedade em classes e, com ela, a divisão do homem; e como esta se torna verdadeiramente tal apenas quando se apresenta como divisão entre trabalho manual e trabalho mental, assim as duas dimensões do homem dividido, cada uma das quais unilateral, são essencialmente as do trabalhador manual, operário e do intelectual. ${ }^{75}$

O operário, “física e mentalmente rebaixado a uma máquina”, é transformado pela "divisão do trabalho cada vez mais unilateral e dependente, considerado pela economia política como besta de carga ou peão, um animal reduzido às mais estritas necessidades corporais”. ${ }^{76}$ Ao lado da divisão do trabalho, como causa da unilateralidade do homem sob o domínio da ideologia capitalista, está a escola burguesa encarregada do seu treinamento e cujo instrumentalismo gera tal embrutecimento do proletariado.

Todo o capítulo sobre Trabalho Alienado é, pois, uma denúncia dessa condição do operário, que tanto mais pobre se torna quanto mais produz riqueza, tanto mais desprovido de valor e dignidade quanto mais cria valores, tanto mais disforme quanto mais toma forma o seu produto, tanto mais embrutecido quanto mais refinado o seu objeto; tanto mais sem espírito e escravo da natureza quanto mais é espiritualmente rico o trabalho. O trabalho produz deformidade, imbecilidade, cretinismo no operário, que se torna um objeto estranho e desumano, no qual

\footnotetext{
${ }^{73}$ MANACORDA, M. A. Marx e a pedagogia moderna. São Paulo: Cortez, 1991, p. 108.

${ }^{74}$ Idem, p. 72.

${ }^{75}$ Idem, p. 67.

${ }^{76}$ Idem, p. 67.
} 
nenhum dos sentidos existe mais $[\ldots]^{77}$

Além de revelar os efeitos danosos da ação unilateralizante perpetrada pelo Capitalismo, Marx e Engels também sustentam que a onilateralidade (do latim omni, todo), ao conceber o homem como um ser total, o desenvolve como um indivíduo completo ou integral. Essa onilateralidade equivale à totalidade de capacidades produtivas, de consumo e bem-estar das quais o operário tem sido historicamente despojado em decorrência da divisão do trabalho.

Marx e Engels, embora não tenham efetivado uma análise específica da questão educacional, em diferentes momentos criticam a perspectiva unilateral da subordinação da escola ao capital sob as relações capitalistas e os mecanismos de burla às parcas conquistas dos trabalhadores contemplados nas cláusulas sobre educação nas leis fabris. Em suas obras, em diferentes momentos, delineiam-se as bases filosóficas de uma concepção omnilateral de educação e de qualificação humana, inscrita no horizonte da instauração de novas relações sociais dentro de uma nova sociedade. ${ }^{78}$

A alienação de um homem pelo outro contrasta nitidamente com essa “exigência da onilateralidade, ou seja, de um desenvolvimento total, completo, multilateral, em todos os sentidos das faculdades e das forças produtivas, das necessidades e da capacidade da sua satisfação" ${ }^{79}$

Analisando o reflexo das relações sociais dominantes nos processos educativos, constata-se a natureza classista, excludente e alienadora do ensino promovido pelo Capitalismo. Completamente dependente da estrutura social causadora dessa marginalidade, a educação exerce então o papel de reforçadora dessa dominação e legitimadora da marginalização das classes subalternas. ${ }^{80}$

Assim, ao longo do desenvolvimento do Capitalismo, verifica-se uma relação entre os interesses burgueses oligárquicos unidimensionais que associam e subordinam o processo educativo ao ciclo produtivo capitalista. A burguesia industrial tem considerado a educação como um fator de produção em contraposição à demanda do proletariado por uma formação onilateral. A ideologia burguesa tem assegurado a subordinação da classe operária à

\footnotetext{
${ }^{77}$ Idem, p. 69.

${ }^{78}$ FRIGOTTO, G. Educação e a crise do capitalismo real. 5. ed. São Paulo: Cortez, 2003, p. 35. ${ }^{79}$ MANACORDA, M. A. Marx e a pedagogia moderna. São Paulo: Cortez, 1991, p. 78-79.

${ }^{80}$ SAVIANI, Dermeval. Escola e democracia: teorias da educação, curvatura da vara, onze teses sobre a educação política. 34. ed. Campinas: Autores Associados, 2001, p. 4-5.
} 
Weltanschauung capitalista mediante a adoção de programas educacionais dedicados à sua formação que impedem o desenvolvimento da sua onilateralidade.

Para Marx, o trabalho é também a atividade pela qual o homem torna-se humano. $\mathrm{O}$ trabalho forma e modifica as estruturas e hierarquias sociais. Através dele surgem a opressão e a dominação. Marx aposta na industrialização e na correlativa racionalização do trabalho, bem como numa distribuição justa dos meios de produção. Com isso, ele tem em vista a eliminação do sofrimento humano e a supressão da dominação. A sociedade burguesa funda-se sobre o esforço da classe trabalhadora, na necessidade desta de vender sua força de trabalho para sobreviver. Para Marx, a emancipação da classe trabalhadora conduziria a libertação de toda a humanidade. ${ }^{81}$

Deste modo, ele propõe um novo tipo de escola que contribua para a superação da ruptura educacional típica do modelo capitalista, que tornou a ciência estranha ao proletariado no processo produtivo e um instrumento de opressão do proletariado, gerando sua marginalidade. ${ }^{82}$ assim, rejeitando a proposta de educação para todos promovida pelo Estado burguês controlado pelas classes dominantes, ele apresenta um modelo de educação de caráter social guiado pelos valores da solidariedade social.

Sem dominar a cultura as classes subalternas não podem conhecer e reivindicar seus direitos, pois se tornam vulneráveis diante das classes dominantes, que lançam mão desses mesmos conteúdos culturais para legitimar e consolidar a sua supremacia. Portanto, se almejam alcançar a emancipação, as classes subalternas não podem ignorar a realidade de que "dominar o que os dominantes dominam é condição de libertação” da exploração. ${ }^{83}$

É interessante salientar a inerente ambivalência ou dupla instrumentalidade da educação. Visto que, se por um lado o sistema educacional pode servir para difundir, reproduzir e perpetuar o modelo de dominação e exploração capitalista, por outro lado, ele também pode funcionar como "uma arma valiosa a ser empregada em favor da emancipação do ser humano, de sua libertação da exploração e do jugo do capital” ${ }^{\sharp 4}$ Em outras palavras, na perspectiva marxista, embora possa ser empregada como um instrumento de inculcação da ideologia dominante, sustenta-se que a educação também pode se constituir em "um dos

\footnotetext{
${ }^{81}$ WULF, C. Antropologia da educação. Campinas: Alínea, 2005, p. 72.

${ }^{82}$ MARX, K.; ENGELS, F. Crítica da educação e do ensino. Lisboa: Moraes, 1978, p. 73.

${ }^{83}$ SAVIANI, D. Escola e democracia: teorias da educação, curvatura da vara, onze teses sobre educação e política. 32. ed. Campinas: Autores Associados, 1999, p. 66.

${ }^{84}$ RODRIGUES, A. T. Sociologia da educação. Rio de Janeiro: DP\&A, 2000, p. 49.
} 
meios de superação da ordem social, injusta e desigual”85 que caracteriza a sociedade capitalista.

Como instrumento de equalização social, ao intervir na realidade, a educação pode transformá-la corrigindo injustiças, promovendo a aceitação e o respeito mútuos entre os cidadãos. Assim, é imprescindível a implementação de uma perspectiva educacional, ao invés de ser “um mecanismo de manutenção da ordem” ${ }^{\text {„6 }}$ que expropria ou aliena o proletariado dos seus instrumentos de produção e saberes, esteja a favor da emancipação do homem.

Portanto, o sistema educacional deve promover o acesso das classes desfavorecidas ao conhecimento sistematizado. A desaprovação das desigualdades sociais e a ênfase na igualdade de acesso e permanência nas instituições escolares estabelecidas com o mesmo padrão de qualidade daquelas dedicadas às classes dominantes são demandas da vertente marxista contra-hegemônica. Assim, urge a adoção de uma visão de educação igualitária, democrática e libertadora apta a contribuir para a transformação das condições sociais das classes subalternas à luz do modelo de homem onilateral. Deste modo, a unidade entre trabalho e ensino é impreterível, pois "ao dividir o trabalho, divide-se igualmente o homem, sendo todas as outras potencialidades intelectuais e físicas sacrificadas ao aperfeiçoamento de uma actividade única” ${ }^{\text {} 87}$. Tal visão educacional caracteriza-se por conceber o homem com um ser que deve ser liberto da consequente degeneração provocada pelo bitolado âmbito do trabalho dividido.

Conclui-se, portanto, que à educação "cabe um papel decisivo na conformação da sociedade evitando sua desagregação e, mais do que isso, garantindo a construção de uma sociedade igualitária" ${ }^{\text {88 }}$. Inclusive, vale ressaltar ainda que "o princípio de que a educação é direito de todos e dever do Estado" “decorria do tipo de sociedade correspondente aos interesses da nova classe que se consolidara no poder: a burguesia" ${ }^{\text {,9 }}$, cujo intento inicial, pelo menos como

\footnotetext{
${ }^{85}$ SILVA, W. C. L; CARVALHO, A. B. Contribuições do materialismo histórico para a educação. In: Sociologia e educação: leituras e interpretações. São Paulo: Avercamp, 2006, p. 51. ${ }^{86}$ RODRIGUES, A. T. Sociologia da educação. Rio de Janeiro: DP\&A, 2000, p. 35.

${ }^{87}$ MARX, K.; ENGELS, F. Crítica da educação e do ensino. Lisboa: Moraes, 1978, p. 10.

${ }^{88}$ SAVIANI, D. Escola e democracia: teorias da educação, curvatura da vara, onze teses sobre a educação política. 34. ed. Campinas: Autores Associados, 2001, p. 4.

${ }^{89}$ Idem, p. 5.
} 
preconizado nas Declarações de Direitos de 1789 e de 1793, seria construir uma sociedade em bases democráticas.

Portanto, visando o processo de mudanças necessárias à emancipação e à humanização do operário como sujeito histórico e cultural de seu tempo, é indispensável a promoção da concepção de educação como um veículo de transformação da realidade social. Para isso, é preciso que se promova um questionamento crítico por parte dos educadores e dos agentes políticos, seguido da mobilização da sociedade civil em torno da reivindicação de seus direitos. É imprescindível que haja uma conscientização da população quanto às relações de poder que se estabelecem nas esferas responsáveis pela elaboração da legislação e pela implementação das políticas públicas educacionais.

\section{3}

\section{A Educação como Aparelho Ideológico do Estado}

Segundo Louis Althusser, que considerava a ideologia como "o sistema das ideias, das representações, que domina o espírito de um homem ou de um grupo social”,90, os Aparelhos Ideológicos de Estado (AIE), entidades diferentes e especializadas, distintas do Aparelho Repressivo de Estado (ARE), que "funciona pela violência” e abrange: o Governo, a Administração, o Exército, a Polícia, os Tribunais, as Prisões, etc. Então, há uma série de $\mathrm{AIE}^{91}$ : o AIE religioso; o AIE escolar (o sistema das diferentes escolas públicas e particulares); o AIE familiar; o AIE jurídico; o AIE político; o AIE sindical; o AIE da informação; o AIE cultural.

Ademais, evidenciam-se algumas distinções entre os Aparelhos Repressivos de Estado (ARE) e os Aparelhos Ideológicos de Estado (AIE) ${ }^{92}$ : para cada aparelho repressivo há uma pluralidade de aparelhos ideológicos em uma unidade que não é visível; enquanto os primeiros pertencem ao domínio público, a maioria dos AIE se insere no domínio privado. Contudo, não interessa muito se essas instituições são "públicas” ou "privadas”. O que importa é o seu funcionamento, pois instituições privadas podem perfeitamente "funcionar" como AIE. A

\footnotetext{
${ }^{90}$ ALTHUSSER, L. Ideologia e aparelhos ideológicos do Estado. 3. ed. Lisboa: Presença/Martins Fontes, 1980, p. 69.

${ }^{91}$ Idem, p. 44.

${ }^{92}$ Idem, p. 44-45.
} 
fundamental distinção entre essas duas categorias é que o aparelho repressivo "funciona de uma maneira massivamente prevalente pela repressão (inclusive física), embora funcione secundariamente pela ideologia”, ao passo que os AIE "funcionam de um modo massivamente prevalente pela ideologia, embora funcionando secundariamente pela repressão, mesmo que no limite, mas apenas no limite, esta seja bastante atenuada, dissimulada ou até simbólica”. 93

A partir da Revolução Francesa, pode-se perceber que, no seu afã de consolidar a laicidade, a burguesia passou a se apossar das funções ideológicas até então desempenhadas exclusivamente pela Igreja (escolares, culturais e de informação), com vistas a assegurar sua hegemonia política e ideológica imprescindível à reprodução das relações de produção. Tal reprodução ocorreu por meio dos aparelhos ideológicos de Estado com a colaboração de um componente externo ao processo produtivo, ou seja, o sistema escolar capitalista.

Deste modo, a partir de então, o aparelho ideológico escolar passou a substituir a Igreja como o Aparelho Ideológico de Estado (AIE) dominante. Inclusive, é interessante observar um ponto em comum entre elas, pois “a escola e as Igrejas “educam” por métodos apropriados de sanções, de exclusões, de seleção, etc." ${ }^{94}$ Contudo, os conteúdos, os métodos, as técnicas e as estratégias de ensino típicos do AIE escolar passaram a ser utilizados de uma forma inusitada e peculiar. Eles também estariam associados aos diversos postos da produção mediante a aprendizagem do "know-how" capitalista para garantir a desejada submissão à ideologia dominante.

Realmente, é notória a utilização do AIE escolar como um instrumento de consolidação da dominação e a exploração do proletariado, pois não há como ignorar que "a sociedade em que vivemos, fundada no modo de produção capitalista, é dividida em classes com interesses opostos; portanto, a escola sofre a determinação do conflito de interesses que caracteriza a sociedade”. ${ }^{95}$

Portanto, pode-se verificar a inculcação maciça da ideologia da classe hegemônica realizada pelo aparelho ideológico escolar nas crianças de todas as

\footnotetext{
${ }^{93}$ Idem, p. 45-46.

${ }^{94}$ ALTHUSSER, L. Ideologia e aparelhos ideológicos do Estado. 3. ed. Lisboa: Presença/Martins Fontes, 1980, p. 79.

${ }^{95}$ SAVIANI, D. Escola e democracia: teorias da educação, curvatura da vara, onze teses sobre a educação política. 34. ed. Campinas: Autores Associados, 2001, p. 30.
} 
classes sociais inicia-se desde a primeira infância. Além disso, apesar de admitir que grande parte da ideologia capitalista possa também ser aprendida fora da escola, ressalte-se que "nenhum aparelho ideológico de Estado dispõe, durante tantos anos, dessa audiência obrigatória (e por menos que isso signifique, gratuita...), 5 a 6 dias num total de 7, numa média de 8 horas por dia, da totalidade das crianças da formação social capitalista". 96

Assim, vale destacar como o AIE escolar atua impondo a ideologia dominante aos alunos e como contribui para a formação profissional dos membros das diversas camadas sociais, cujas funções sociais e ocupacionais são também por ele determinadas. Inclusive, as relações dicotômicas (patrão-empregado, burguês-proletariado) são reproduzidas no próprio contexto do AIE escolar, visando assegurar as relações de produção requeridas pelo sistema.

Ela se encarrega das crianças de todas as classes sociais desde o Maternal, e desde o Maternal ela lhes inculca, durante anos, precisamente durante aqueles em que a criança é mais "vulnerável”, espremida entre o aparelho de Estado familiar e o aparelho de Estado escolar, os saberes contidos na ideologia dominante (o francês, o cálculo, a história natural, as ciências, a literatura) ou simplesmente a ideologia dominante em estado puro (moral, educação cívica, filosofia). Por volta do 16 . ano, uma enorme massa de crianças entra na "produção", são operários ou pequenos camponeses. Uma outra parte da juventude escolarizável prossegue: e, seja como for, caminha para os cargos dos pequenos e médios quadros, empregados, funcionários pequenos e médios, pequenos burgueses de todo o tipo. Uma última parcela chega ao final do percurso, seja para cair num semidesemprego intelectual, seja para fornecer além dos "intelectuais do trabalhador coletivo”, os agentes da exploração (capitalistas, gerentes) os agentes da repressão (militares, policiais, políticos, administradores) e os profissionais da ideologia (padres de toda a espécie, que em sua maioria são "leigos" convictos). ${ }^{97}$

Assim, a educação serve aos interesses do Estado e da classe dominante, com vistas à manutenção da ordem social vigente, por meio de um discurso ideológico alienante, que perpetua as relações de produção, assim como a distribuição socioeconômica desigual. Quanto aos conhecimentos, habilidades e competências que o AIE escolar desenvolve no cumprimento do seu papel como um meio de reafirmação do modo de produção capitalista e de reprodução da lógica de dominação excludente da elite dominante burguesa, ressalte-se que:

Porém, ao mesmo tempo, e junto com essas técnicas e conhecimentos, aprendem-se na escola as "regras" do bom comportamento, isto é as conveniências que devem

\footnotetext{
${ }^{96}$ ALTHUSSER, L. Aparelhos ideológicos de Estado: nota sobre os aparelhos ideológicos de Estado (AIE). 6. ed. Rio de Janeiro: Graal, 1992, p. 80.

${ }^{97}$ ALTHUSSER, L. Aparelhos ideológicos de Estado: nota sobre os aparelhos ideológicos de Estado (AIE). 6. ed. Rio de Janeiro: Graal, 1992, p. 79.
} 
ser observadas por todo agente da divisão do trabalho conforme o posto que ele esteja "destinado" a ocupar; as regras de moral e de consciência cívica e profissional, o que na realidade são regras de respeito à divisão social-técnica do trabalho e, em definitivo, regras da ordem estabelecida pela dominação de classe. Aprende-se também a "falar bem o idioma", a "redigir bem", o que na verdade significa (para os futuros capitalistas e seus servidores) saber "dar ordens", isto é, (solução ideal) dirigir-se adequadamente aos operários etc... [...] a reprodução da força de trabalho não exige somente uma reprodução de sua qualificação mas ao mesmo tempo uma reprodução de sua submissão às normas da ordem vigente, isto é, uma reprodução da submissão dos operários à ideologia dominante. ${ }^{98}$

Assim, visando perpetuar sua hegemonia, a elite burguesa tem se utilizado desse novo AIE. Por sua vez, paradoxalmente, a maioria dos cidadãos destinatários do direito à educação, dificilmente percebe tal manipulação ideológica. A sociedade capitalista torna-se natural e é concebida como a única ordem social viável. Então, uma vez expropriados dos meios de produção e do saber mediante o processo de alienação, os dominados tornam-se dependentes dos capitalistas, mas "não têm uma consciência real da dominação de que são objeto". 99 Portanto, constata-se que "a ideologia impede que o proletário tenha consciência da própria submissão, porque camufla a luta de classes ao representar, de forma ilusória, a sociedade, mostrando-a como uma e harmônica.”100

Por causa do trabalho alienado a que estão submetidos, os homens adquirem uma consciência falsa do mundo em que vivem, veem o trabalho alienado e a dominação de uma classe social sobre outra como fatos naturais e passam, portanto, a compartilhar uma concepção de mundo dentro da qual só têm a cesso às aparências, sem ser capazes de compreender o processo histórico real. A isso Marx dá o nome de ideologia. A ideologia, portanto, é aquele sistema ordenado de ideias, de concepções, de normas e de regras (com base no qual as leis jurídicas são feitas) que obriga os homens a comportarem-se segundo a vontade "do sistema", mas - e isso é importante - como se estivessem se comportando segundo sua própria vontade. ${ }^{101}$

Inclusive, é relevante enfatizar que "a suprema ironia do capitalismo é que o dominado pensa com a cabeça do dominador” ${ }^{102}$, pois a ideologia dominante já está incutida em sua mente mediante o emprego da educação e de outros instrumentos disseminadores da visão de mundo da burguesia privilegiada e da perpetuação da opressão da classe trabalhadora. Então, já que a transformação histórica da escola não interessa à classe dominante, que está dedicada à

\footnotetext{
${ }^{98}$ Idem, p. 58.

${ }^{99}$ RODRIGUES, A. T. Sociologia da educação. Rio de Janeiro: DP\&A, 2000, p. 43.

${ }^{100}$ SILVA, W. C. L.; CARVALHO, A. B. Contribuições do materialismo histórico para a educação. In Sociologia e educação: leituras e interpretações. São Paulo: Avercamp, 2006, p. 43.

${ }^{101}$ RODRIGUES, A. T. Sociologia da educação. Rio de Janeiro: DP\&A, 2000, p. 46.

${ }^{102}$ Idem, p. 47.
} 
manutenção da sua supremacia, qualquer empreitada com vistas à alteração da conjuntura em vigor "só poderá ser formulada do ponto de vista dos interesses dos dominados. $^{103}$

Desta forma, é válido assinalar o papel ideológico incontestável da escola, representada, a princípio, propositalmente como um meio neutro e desprovido de ideologia, na produção de indivíduos com a finalidade de servir às necessidades dos grupos hegemônicos da sociedade capitalista. De acordo com essa perspectiva, a escola produz indivíduos úteis, ajustados e apropriados à disposição da sociedade capitalista ao equipá-los com atitudes, inclinações ideológicas e conhecimentos interessantes e proveitosos sob a ótica do sistema de produção.

Portanto, mais uma vez manifesta-se o caráter ambivalente da educação. Uma vez que, embora possa ser vista como um instrumento de promoção da emancipação humana e um direito fundamental conquistado a duras penas ao longo da História, ela também pode ser utilizada como o principal aparelho ideológico do Estado capitalista a serviço da classe dominante, pois é responsável pela formação de cidadãos ou meras forças produtivas.

\section{4}

\section{A Educação na Sociedade Disciplinar}

Michel Foucault associa o projeto de “panopticon” do jurista inglês Jeremy Bentham (fundador do utilitarismo) ao processo iniciado na Idade Moderna pelo qual se constitui a "Sociedade Disciplinar" formada nos séculos XVII e XVIII. Ela se caracteriza pela existência de instituições fechadas destinadas ao controle social, com fundamento na monitoração, vigilância, hierarquia e dominação constantes dos indivíduos em diversos âmbitos sociais como fábricas, escolas, prisões, hospícios, quartéis, etc. Assim, ela caracteriza perfeitamente a forma de poder pela qual a burguesia exerce e visa perpetuar sua hegemonia.

Assim, Foucault empreende uma interpretação da sociedade em função das múltiplas e intrincadas relações de poder que perpassam, caracterizam e compõem o tecido social. Investigando a genealogia dos micropoderes, ele conclui que o

\footnotetext{
${ }^{103}$ SAVIANI, D. Escola e democracia: teorias da educação, curvatura da vara, onze teses sobre a educação política. 34. ed. Campinas: Autores Associados, 2001, p. 30.
} 
poder constitui-se em uma prática social expressa por um conjunto de relações que se exerce e opera entre os indivíduos. Consequentemente, o poder não se restringe ao governo, mas alastra-se pelo corpo social em um conjunto de práticas e relações, a maioria indispensável à conservação do Estado.

Paralelo ao poder central e disseminado por toda parte e não emanando somente das instituições estatais centrais, o poder deve ser compreendido como uma relação difusa e flutuante que provoca ações inclusive no campo do direito. Ele pode ser concebido como um tipo de rede inevitável composta por mecanismos e dispositivos que se espalham por todo o cotidiano, moldando comportamentos, atitudes e discursos.

[...] não se trata de analisar as formas regulamentadas e legítimas do poder em seu centro, no que podem ser seus mecanismos gerais ou seus efeitos de conjunto. Trata-se de apreender, ao contrário, o poder em suas extremidades, em seus últimos lineamentos, onde ele se torna capilar; ou seja, tomar o poder em suas formas e em suas instituições mais regionais, mais locais, sobretudo no ponto em que esse poder, indo além das regras de direito que o organizam e o delimitam, se prolonga, em consequência, mais além dessas regras, investe-se em instituições, consolida-se nas técnicas e fornece instrumentos de intervenção materiais, eventualmente até violentos. ${ }^{104}$

Ressalte-se que, analisando a mudança de comportamento no âmbito dessas instituições, Foucault procura compreender os processos da produção dos saberes que possibilitam esse controle difuso que ele denomina de microfísica do poder.

[...] não tomar o poder como um fenômeno de dominação maciço e homogêneo dominação de um indivíduo sobre os outros, de um grupo sobre os outros, de uma classe sobre as outras -; ter bem em mente que o poder, exceto ao considerá-lo de muito alto e de muito longe, não é algo que se partilhe entre aqueles que o têm e que o detêm exclusivamente, e aqueles que não o têm e que são submetidos a ele. O poder, acho eu, deve ser analisado como uma coisa que circula, ou melhor, como uma coisa que só funciona em cadeia. Jamais ele está localizado aqui ou ali, jamais está entre as mãos de alguns, jamais é apossado como uma riqueza ou um bem. O poder funciona. O poder se exerce em rede e, nessa rede, não só os indivíduos circulam, mas estão sempre em posição de ser submetidos a esse poder e também de exercê-lo. Jamais eles são o alvo inerte ou consentidor do poder, são sempre seus intermediários. Em outras palavras, o poder transita pelos indivíduos, não se aplica a eles. ${ }^{105}$

$\mathrm{Na}$ sua teoria da docilidade dos corpos, Foucault evidencia a passagem da marcação dos corpos ao disciplinamento da alma como a principal forma de

\footnotetext{
${ }^{104}$ FOUCAULT, M. Em defesa da sociedade: curso no Collège de France. São Paulo: Martins Fontes. 2002, p. 32.

${ }^{105}$ FOUCAULT, M. Em defesa da sociedade: curso no Collège de France. São Paulo: Martins Fontes. 2002, p. 34-35.
} 
exercício de poder mediante a aplicação de técnicas e táticas da dominação.

Analisando-se os métodos de disciplina aplicados nos conventos, exércitos e nas oficinas, constata-se que era imposta aos corpos uma condição ou relação de docilidade e utilidade mediante a sujeição contínua de suas forças. Essas disciplinas promoveriam a sujeição dos corpos, o que culminaria na docilidade dos mesmos. Inclusive, vale enfatizar que "é dócil um corpo que pode ser submetido, que pode ser utilizado, que pode ser transformado e aperfeiçoado”. ${ }^{106}$

Deste modo, manifesta-se nitidamente o caráter ideológico dos sistemas carcerário, dos hospícios e, principalmente, o "sistema do direito e o campo judiciário” que representam o "veículo permanente de relações de dominação, de técnicas de sujeição polimorfas”. ${ }^{107}$

Portanto, é relevante a investigação sobre o poder, seus objetos, alvos, campos de aplicação, assim como sobre as esferas onde ele se implanta e produz seus efeitos reais, para que se possa descobrir e interpretar acontecimentos e seus respectivos efeitos ao longo dos processos contínuos e ininterruptos de sujeição.

É preciso compreender tais processos de tecnologia de poder que docilizam os corpos, dirigindo seus gestos e regendo seus comportamentos mediante a aplicação de disciplinas com vistas ao aumento de suas forças (em termos econômicos de utilidade) e diminuição das mesmas (em termos políticos de obediência). ${ }^{108}$ Assim Foucault denuncia a existência e o funcionamento da “Sociedade de Normalização”:

Eu creio que o processo que tornou fundamentalmente possível o discurso das ciências humanas foi a justaposição, o enfrentamento de dois mecanismos e de dois tipos de discursos absolutamente heterogêneos: de um lado, a organização do direito em torno da soberania, do outro, a mecânica das coerções exercidas pelas disciplinas. Que, atualmente, o poder se exerça ao mesmo tempo através desse direito e dessas técnicas, que essas técnicas da disciplina, que esses discursos nascidos da disciplina invadam o direito, que os procedimentos da normalização colonizem cada vez mais os procedimentos da lei, é isso, acho eu, que pode explicar o funcionamento global daquilo que eu chamaria uma "sociedade de normalização". ${ }^{109}$

Ele vai ainda mais além ao estabelecer um nexo entre poder e saber que ele

\footnotetext{
${ }^{106}$ FOUCAULT, M. Vigiar e punir: nascimento da prisão. Petrópolis: Vozes, 1999, p. 118.

${ }^{107}$ Op. Cit., p. 32.

${ }^{108}$ FOUCAULT, M. Em defesa da sociedade: curso no Collège de France. São Paulo: Martins Fontes. 2002, p. 33.

${ }^{109}$ Idem, p. 46.
} 
revela a existência de controle e de delimitação do discurso que, apoiados em suportes institucionais, são reforçados "por todo um compacto conjunto de práticas como a pedagogia, é claro, como o sistema dos livros, da edição, das bibliotecas, como as sociedades de sábios outrora, os laboratórios hoje” ${ }^{110}$.

Propõe-se o estudo do fenômeno do poder fora do modelo delimitado pela soberania jurídica e pela instituição do Estado, mas a partir daquilo que ele considera como tecnologias, técnicas e táticas de dominação que assegura a irrigação do poder por todo o corpo social visando a dominação.

Ora, nos séculos XVII e XVIII ocorreu um fenômeno importante: o aparecimento deveríamos dizer a invenção - de uma nova mecânica do poder, que tem procedimentos bem particulares, instrumentos totalmente novos, uma aparelhagem muito diferente e que, acho eu, é absolutamente incompatível com as relações de soberania. Essa nova mecânica de poder incide primeiro sobre os corpos e sobre o que eles fazem, mais do que sobre a terra e sobre o seu produto. É um mecanismo de poder que permite extrair dos corpos tempo e trabalho, mais do que bens e riqueza. É um tipo de poder que se exerce continuamente por vigilância e não de forma descontínua por sistemas de tributos e de obrigações crônicas. É um tipo de poder que pressupõe muito mais uma trama cerrada de coerções materiais do que a existência física de um soberano, e define uma nova economia de poder cujo princípio é o de que se deve ao mesmo tempo fazer que cresçam as forças sujeitadas e a força e a eficácia daquilo que as sujeita. ${ }^{111}$

À luz da análise foucaultiana sobre o modus operandi dos mecanismos que produzem indivíduos economicamente produtivos e politicamente dóceis e, simultaneamente, os levam à subordinação ou sujeição a partir de procedimentos de dominação e normalização, é inevitável considerar o papel da escola, juntamente com a família, como agente por excelência das técnicas de normalização. É válida aqui a menção do pensamento de Alfredo Veiga-Neto:

É quase uma banalidade afirmar que a escola vem funcionando, ao longo dos últimos quatro séculos, como a mais importante instituição capaz de moldar disciplinarmente os indivíduos que ela toma para si. A imensa maioria de nós aprende a ser disciplinar (e, no limite, disciplinada), graças às ações das máquinas - como o currículo, o panóptico, as fichas simbólicas etc. - que compõem essa grande maquinaria escolar. Como detalhadamente demonstrou Michel Foucault, a escola constitui-se, enfim, como uma instituição crucial para a instauração da sociedade disciplinar que hoje conhecemos. ${ }^{112}$

A instituição escolar, consagrada como um dos primeiros objetos do poder disciplinar foi sendo idealizada como a grande e universal máquina de

\footnotetext{
${ }^{110}$ FOUCAULT, M. A ordem do discurso. 9. ed. São Paulo: Loyola, 2003, p. 17.

${ }^{111}$ Op. Cit., p. 42.

${ }^{112}$ VEIGA-NETO, A. Crise da modernidade e inovações curriculares: da disciplina para o controle, 2008, p. 145.
} 
adestramento de corpos ainda tenros e flexíveis, com vistas a torná-los dóceis. É interessante notar ainda nos dias atuais exteriorizações do poder disciplinar que a escola exercita sobre os corpos.

Assim, a escola como participante ativa da "sociedade disciplinar", transformou-se em uma instituição responsável pela fabricação e manutenção e perpetuação do que se entende por normalidade, mediante a aplicação da sua tecnologia de poder. Como exemplos dessa disciplina estão: as ações metodológicas desenvolvidas pelos professores para o ensino e aprendizagem no cotidiano escolar, os pátios escolares nos quais se formam filas de alunos para entrar nas salas de aula e a domesticação com o controle das suas vontades corporais (fome, sede, necessidades fisiológicas, etc.).

Logo, conclui-se que a escola funciona como campo fundamental para aplicação e exercício dos instrumentos e mecanismos típicos das tecnologias do poder disciplinar, destacando-se, inclusive, pelas suas funções de registro e documentação minuciosa em relação à aptidão, capacidade, nível de eficiência e progressos do corpo discente ${ }^{113}$.

Deste modo, torna-se inevitável associar tal papel disciplinar da escola aos interesses do Estado, visando assegurar a produção de um estereótipo de cidadão ideal. É exatamente neste ponto que se manifesta o caráter ambivalente da educação. Em outras palavras, a princípio, a educação possui a potencialidade de contribuir para a promoção da libertação do homem. Porém, conforme exposto, por outro lado, o outro aspecto que o sistema educacional pode assumir é de um instrumento de controle e disciplina do cidadão.

\footnotetext{
${ }^{113}$ FOUCAULT, M. Vigiar e punir: nascimento da prisão. Petrópolis: Vozes, 1999, p. 158.
} 


\section{3 O Processo de Formação dos Instrumentos de Promoção
do Direito Fundamental à Educação Básica}

Com efeito, é muito importante neste ponto específico deixar claro o vínculo ou relação entre as argumentações expostas nos dois primeiros capítulos desta dissertação e o conteúdo a ser apresentado neste capítulo.

Após a exposição dos fundamentos sociais, históricos, políticos e ideológicos que prenunciaram o direito à educação básica, incluindo o exame do legado político-ideológico transmitido pela Revolução Francesa para a compreensão da evolução da concepção desse direito, além da apreciação do caráter ambivalente da educação como promotora da onilateralidade ou da dominação ideológica, empreende-se uma análise dos processos legislativos que antecederam a promulgação dos dois referidos diplomas normativos garantidores do direito à educação básica.

Diante de todo o exposto, o presente capítulo tem como objetivo principal expor e sondar os processos parlamentares de discussão e formulação dos diplomas normativos de efetivação do direito fundamental à educação básica no Brasil, a saber, a Constituição Federal de 1988 e a Lei nº 9.394/96 (LDB).

Entretanto, primeiramente, antes da apresentação e da análise da conjuntura política que envolveu tais processos legislativos, é mister que se realize uma análise retrospectiva, da evolução da abordagem da temática da educação ao longo da história do constitucionalismo pátrio. Portanto, o propósito da primeira parte deste capítulo é apresentar a forma como o tema educação foi tratado nos diversos textos constitucionais que vigoraram ao longo da história do Brasil.

Em seguida, expõe-se e analisa-se o cenário político marcado pelos debates e embates nas comissões da Assembleia Nacional Constituinte (ANC) de 19871988 em torno do teor da Seção I “Da Educação” (Artigos 205 a 214), de acordo com o constante nas atas das suas sessões e registrado no Diário da própria Assembleia Constituinte.

Finalmente, apresenta-se dinâmica do contexto parlamentar gerador da LDB em ambas as casas do Congresso Nacional. Isto é, examina-se a discussão, a votação, a tramitação e a deliberação de propostas e projetos de lei oriundos tanto 
da Câmara dos Deputados quanto do Senado Federal.

\section{1 \\ Uma Análise Retrospectiva da Abordagem da Educação ao Longo da História do Constitucionalismo Brasileiro}

À guisa de introdução ao processo de análise dos respectivos contextos políticos que ensejaram a elaboração das atuais previsões constitucional e legal referentes à educação básica, empreende-se uma exposição da tradição constitucionalista, dos muitos exemplos de expressão e da tônica historicamente assumida pelo poder constituinte pátrio durante as discussões e deliberações relacionadas a esse tema.

Tal enfoque justifica-se pela inegável importância do exame dos cenários parlamentares e sociopolíticos que envolveram os processos de debates e decisões anteriores à promulgação das diversas constituições brasileiras para a compreensão das vocações ou inclinações das políticas públicas educacionais adotadas nos períodos imperial e republicano.

Preliminarmente, pode-se observar que parece haver uma conexão entre o nível de relevância atribuída à educação ao longo da história constitucional brasileira e a frequência com que ela é mencionada nas diversas Cartas Magnas. Em outras palavras, ao passo que nas Constituições de 1824 e 1891 as referências à temática educacional são raras, pode-se perceber um expressivo aumento na frequência de dispositivos constitucionais concernentes a esse tópico nas Constituições de 1934, 1937, 1946, 1967 e $1988 .^{114}$

No que tange à Constituição de 25 de março de 1824, a conjuntura política que antecedeu sua outorga caracterizou-se, pelo poder concentrado nas mãos do imperador, pelo voto indireto e censitário, além do caráter patrimonialista, escravagista e oligárquico da sociedade. Tudo isso resultou em uma atuação parlamentar marcada muito mais pela eloquência do que pela relevância prática no

\footnotetext{
${ }^{114}$ VIEIRA, S. L. A educação nas constituições brasileiras: texto e contexto. R. Bras. Est. Pedag. Brasília, v. 88, n. 219, p. 291-309, maio/ago. 2007, p. 291.
} 
que se refere às propostas de diretrizes basilares para a educação na época. ${ }^{115}$

Convocada em 3 de junho de 1822, a pioneira Assembleia Constituinte e Legislativa brasileira, era composta por representantes das classes dominantes e privilegiadas. Contudo, "desde o início dos trabalhos, entretanto, os constituintes de 1823 entraram em choque com a tendência absolutista de D. Pedro I". ${ }^{116}$

Em decorrência disso, o limitado produto dos debates concernentes à educação ocorridos no âmbito da Comissão de Instrução Pública da Constituinte nem mesmo chegou a ser inserido na Constituição Imperial devido à dissolução da Assembleia Constituinte em 12 de novembro de $1823^{117}$.

Inclusive, ressalte-se que, as duas únicas menções à educação estão no artigo 179. Ao abordar a "A inviolabilidade dos Direitos Civis, e Políticos dos Cidadãos Brasileiros", o mencionado dispositivo preconizava "A Instrução primária, e gratuita a todos os Cidadãos" (inciso XXXII) e se referia aos "Colégios, e Universidades, aonde serão ensinados os elementos das Ciências, Belas Letras, e Artes" (inciso XXXIII).

Ressalte-se que, embora não tenha sido concretizada na realidade, essa previsão constitucional de gratuidade da instrução primária para todos consistiu em um significativo e notável avanço na concepção de direito à educação, que lamentavelmente não foi mantido no teor da Carta republicana de 1891.

Contudo, como consequência da demasiada ênfase no ensino superior no teor dos projetos apresentados pelos constituintes, “a educação básica ficou absolutamente relegada à iniciativa privada até o Ato Adicional de 1834.”118 Deste modo, vale ainda destacar aqui a crítica de Anísio Teixeira em relação à hipocrisia da elite dirigente durante o período do Império pois, através dos seus representantes, limitou-se aos debates improdutivos, apesar de ter levantado a bandeira da valorização da educação popular. ${ }^{119}$

Ainda no que concerne a esse contexto sociopolítico, é imprescindível

\footnotetext{
${ }^{115}$ CHIZZOTTI, A. A constituinte de 1823 e a educação. In: FÁVERO, O. (Org.) A educação nas constituintes brasileiras: 1823-1988. 2. ed. Campinas: Autores Associados, 2001, p. 50.

${ }^{116}$ DEIRÓ, P. E. S. Fragmentos de estudos da história da Assembléia Constituinte do Brasil. Brasília: Senado Federal, 2006, p. 12.

${ }^{117}$ CHIZZOTTI, A. A constituinte de 1823 e a educação. In: FÁVERO, O. (Org.) A educação nas constituintes brasileiras: 1823-1988. 2. ed. Campinas: Autores Associados, 2001, p. 50.

${ }^{118}$ Idem, p. 50.

${ }^{119}$ SUCUPIRA, N. O ato adicional de 1834 e a descentralização da educação. In: Op. Cit., p. 66.
} 
destacar a Confederação do Equador, proclamada em 2 de julho de 1824, que consistiu em um movimento separatista republicano desencadeado em algumas províncias nordestinas que se insurgiram contra o absolutismo do imperador D. Pedro I. O objetivo desse movimento era a instituição de um novo Estado totalmente independente do Império e estabelecido segundo um modelo de governo representativo, liberal e republicano que assegurasse a autonomia e o desenvolvimento das províncias confederadas.

As causas para a deflagração da revolta foram: a dissolução da Constituinte de 1823, a outorga da Carta de 1824, a centralização política imposta pelo imperador e a nomeação de Francisco Pais Barreto para ocupar o cargo de Manuel Paes de Andrade como presidente da província de Pernambuco. Contrariados, Manuel de Carvalho Paes de Andrade e Frei Joaquim do Amor Divino Caneca, os líderes liberais e republicanos do levante, pretendiam estabelecer uma nova república, cujo território abrangeria as províncias da Bahia até o Grão-Pará.

Na província de Pernambuco, o centro do levante, o movimento contou com grande participação popular. A partir do seu início em Pernambuco, a insurreição irradiou-se com velocidade por diversas províncias da região nordestina, tais como Ceará, Rio Grande do Norte e Paraíba.

Por sua vez, Frei Caneca convocou os cidadãos para a celebração de um pacto social com vistas à composição de uma sociedade instituída com base no respeito à liberdade individual e em prol da felicidade humana. Ele conciliava a concepção do pacto social à produção de uma Carta Magna que manifestasse a soberania da nação e a proteção dos direitos como expressão garantidora do contrato firmado entre os envolvidos.

As bases para a consolidação desse pacto social foram apresentadas no artigo "Bases para a Formação do Pacto Social Redigidas por uma Sociedade de Homens de Letras", publicado por Frei Caneca no seu jornal "Typhis Pernambucano". Os dispositivos desse pacto consistiam em suportes políticos e filosóficos que instituiriam e conduziriam a nova república, representando uma veemente oposição aos regimes colonial e imperial.

Inclusive, deve-se assinalar que, guardadas as devidas proporções, o clima sociopolítico em Pernambuco era parecido ao que ocorreu na França na época da 
Revolução Francesa. Com princípios inspirados nos ideais promovidos ao longo das fases mais liberais e democráticas da Revolução Francesa, previa-se a garantia à igualdade, a justiça social, a resistência à opressão, a soberania nacional e o direito do povo rever a Constituição.

Além disso, é indispensável ressaltar que Frei Caneca acreditava que era preciso precipuamente promover a instrução do povo tanto para que ele pudesse contribuir para a formação da nova pátria quanto para que usufruísse dessa nova realidade social. Assim, vale salientar que o artigo 22 do seu anteprojeto para a Constituição estabelecia que "A instrução elementar é necessária, a todos, e a sociedade a deve prestar igualmente a todos os seus membros”.

Em outras palavras, nitidamente sob a influência do espírito liberal e democrático revolucionário francês, Frei Caneca expressou nesse artigo sua crença na instrução popular básica como princípio fundamental e imprescindível para a constituição da nova nação e o desenvolvimento da civilização pelo esclarecimento e através das luzes do conhecimento.

Ademais, pode-se identificar no supramencionado dispositivo a clara defesa dos mesmos princípios de educação universal e garantia de igualdade no acesso à educação básica que já haviam sido consagrados e propalados pelos líderes democratas do movimento revolucionário francês.

Desta forma, pode-se constatar que os ideais e princípios de educação universal, igualitária e gratuita, defendidos e apregoados pelos líderes da Revolução Francesa, chegaram ao Brasil por duas vias contrapostas.

Em outras palavras, apesar do antagonismo entre as posições políticas assumidas pelo Imperador D. Pedro I e o revolucionário Frei Caneca, ambos os seus respectivos projetos de constitucionalização de garantia e promoção da educação primária evidenciam traços da influência do ideário revolucionário francês característico das suas fases mais democráticas.

Por outro lado, a Constituição da República dos Estados Unidos do Brasil, promulgada em 24 de fevereiro de 1891, marcou a transição do Império para a República. Ela surge em um cenário político marcado pela tripartição dos poderes, pela instituição do voto universal e direto, além da forma política de elaboração democrática da Constituição através de um Congresso Constituinte. 
Ademais, a primeira constituinte republicana caracterizou-se por nutrir a esperança de um novo projeto para a instrução popular. Inclusive, vale enfatizar que o texto constitucional inova com a introdução do princípio republicano da laicidade do ensino em sentido amplo, ao preconizar que seria "leigo o ensino ministrado nos estabelecimentos públicos" (art. 72, § $6^{\circ}$ ). Por outro lado, um aspecto negativo do texto que merece ser ressaltado é a vedação ao alistamento eleitoral aos analfabetos previsto no artigo $70, \S 1^{\circ}, 2^{\circ}$, pois representou uma notória ofensa ao direito à cidadania e à igualdade dos cidadãos iletrados.

Apesar da influência exercida por alguns grupos oligárquicos dominantes como visão excludente, “a Constituinte avançou no sentido da defesa da plenitude dos direitos civis, ampliou um pouco os direitos políticos e omitiu-se ante (ou mesmo negou) os direitos sociais” 120 .

Entretanto, pode-se considerar que “a educação teria sido o único direito social insinuado no campo dos direitos civis”, ${ }^{121}$ só que sua obrigatoriedade ficou inviabilizada pelo fato de ter sido indevidamente deixada a cargo da iniciativa individual de cada cidadão.

Além disso, a quase completa ausência de dispositivos concernentes à educação na Carta Magna de 1891 inevitavelmente se refletirá no histórico de formulação das políticas públicas educacionais pátrias a partir de então.

A Assembleia Constituinte instaurada em novembro de 1933 que elaborou a Constituição promulgada em 16 de julho de 1934, dotou-a de uma característica inerente à era na qual ela foi promulgada, ou seja, o período do governo de Getúlio Vargas: o estabelecimento de diretrizes sociais.

Inclusive, o contexto histórico dessa Constituinte caracterizou-se pela crise do Estado oligárquico, a concessão do direito de voto às mulheres e aos menores de 18 anos, a consagração dos direitos trabalhistas, a aprovação dos direitos e garantias individuais, a instituição do Ministério de Educação e Saúde em 1930 e a influência do escolanovismo expresso no "Manifesto dos Pioneiros da Escola

\footnotetext{
${ }^{120}$ CURY, C. R. J. A educação e a primeira constituinte republicana. In: FÁVERO, Osmar. (Org.) A educação nas constituintes brasileiras: 1823-1988. 2. ed. Campinas: Autores Associados, 2001, p. 79.

${ }^{121}$ Idem, p. 79.
} 
Nova” de $1932 .{ }^{122}$

Anísio Teixeira identificou a insistente presença de padrões patrimonialistas na sociedade brasileira que tornaram privada a ordem pública. As raízes desse fenômeno remontam aos tempos coloniais que têm se consolidado ao longo do período republicano, seja nas reformas de ensino implementadas pela Revolução de 1930, seja na concepção de educação do estado Novo. Tudo isso revela-se na distinção entre um ensino elementar e profissional para o povo e a formação cultural para as classes dominantes. Assim, o contexto histórico que precedeu o processo constituinte de 1933-34 foi marcado pelo confronto entre os atores políticos defensores da tradição e os partidários das modernizações na política educacional brasileira. ${ }^{123}$

Inclusive, Anísio reconhece a intenção da Convenção Revolucionária Francesa de superar as “castas” e formular o ideal de uma educação escolar para todos os cidadãos, não objetivando a universalização da escola, “mas em uma nova concepção de sociedade em que privilégios de classe, de dinheiro e de herança não existissem, e o indivíduo pudesse buscar, pela escola, a sua posição na vida social.”,124

Portanto, expresso em um documento que delineia o ideário pedagógico baseado no ponto de vista de um grupo de intelectuais e educadores de vanguarda, o "Manifesto" marcou o início do projeto de renovação da educação nacional. Ao considerar a educação como um problema nacional de relevância e gravidade sem comparação, o texto destina-se a promover a seu acesso a todos sem qualquer discriminação de classe social.

Apesar das suas distintas e respectivas concepções ideológicas, os envolvidos defendiam, em uníssono, a tese de que a educação pode contribuir para estruturar a organização socioeconômica e direcionar os rumos da sociedade. Contudo, cumpre salientar o tom realista de Darcy Ribeiro ao considerar tantos as finalidades quanto os resultados do "Manifesto".

\footnotetext{
${ }^{122}$ VIEIRA, S. L. A educação nas constituições brasileiras: texto e contexto. R. Bras. Est. Pedag. Brasília, v. 88, n. 219, p. 291-309, maio/ago. 2007, p. 296.

${ }^{123}$ ROCHA, M. B. M. Tradição e modernidade na educação: o processo constituinte de 1933-34. In: FÁVERO, O. (Org.) A educação nas constituintes brasileiras: 1823-1988. 2. ed. Campinas: Autores Associados, 2001, p. 119-120.

${ }^{124}$ TEIXEIRA, A. S. Educação não é privilégio. 4. ed. São Paulo: Nacional, 1977, p. 11-12.
} 
O manifesto dos Pioneiros da Educação, firmado por Anísio Teixeira, Fernando de Azevedo, Lourenço Filho, Hermes Lima, Paschoal Leme, Afrânio Peixoto, Heitor Lira, Cecília Meireles e Julio de Mesquita Filho, conclama o povo e o governo à reconstrução educacional do Brasil como tarefa fundamental da nação. Queriam boa educação pública, leiga, obrigatória e gratuita. Não são atendidos e o eco ainda ressoa, desouvido. ${ }^{125}$

Além disso, estabelece-se uma correlação entre a educação e o desenvolvimento das "forças econômicas ou de produção". Por isso, criticando a notória dissociação entre as reformas econômicas e educacionais ao longo da história republicana, seus subscritores propõem também uma profunda reflexão em relação às consequências da separação entre a educação e os demais fatores sociais de importância para o desenvolvimento nacional.

Critica-se ainda a insistência na "aplicação periódica de reformas parciais e frequentemente arbitrárias, lançadas sem solidez econômica e sem uma visão global do problema"126 e lamenta-se a ausência de um sistema de organização escolar adequado às necessidades nacionais.

Os autores do documento acusam os idealizadores dos antigos planos educacionais de prescindirem da "determinação dos fins de educação (aspecto filosófico e social) e da aplicação (aspecto técnico) dos métodos científicos aos problemas de educação"127.

Consequentemente, enfatiza-se que a solução desses problemas estaria a cargo de educadores dotados de uma visão mais ampla que lhes permite enxergar a manipulação da evolução social e, ao conceberem o "problema educacional em conjunto", podem promover os fins da educação.

Denuncia-se também o descompasso entre os anacrônicos planos e métodos de educação promovidos no Brasil desde 1891 e os avanços verificados nas indústrias e nos transportes nesse mesmo período. Portanto, propunha-se um movimento de renovação educacional inspirado por novos ideais de educação com vistas a possibilitar à escola o retorno à posição de influenciar o meio social no qual está inserida.

\footnotetext{
${ }^{125}$ RIBEIRO, D. Aos trancos e barrancos: como o Brasil deu no que deu. Rio de Janeiro: Guanabara, 1985, nota 729.

${ }^{126}$ O Manifesto dos Pioneiros da Educação Nova (1932). Revista HISTEDBR On-line, Campinas, n. especial, p. 188-204, ago. 2006, p. 188.

${ }^{127}$ Idem, p. 188.
} 
Mas, do direito de cada indivíduo à sua educação integral, decorre logicamente para o Estado que o reconhece e o proclama, o dever de considerar a educação, na variedade de seus graus e manifestações, como uma função social e eminentemente pública, que ele é chamado a realizar, com a cooperação de todas as instituições sociais. ${ }^{128}$

Os autores do Manifesto apresentaram um modelo de escola pública unificada, marcado por princípios tais como a laicidade, a gratuidade, a obrigatoriedade e a coeducação, sempre fundamentado no reconhecimento do direito à educação de todos os cidadãos. É interessante notar que o texto explicita cada um dos princípios que fundamentam a nova perspectiva educacional.

Assim, a laicidade elevaria a escola acima de dogmas e conflitos religiosos, libertando os educandos de pressões doutrinárias e sectárias. Por sua vez, a gratuidade, como princípio igualitário atrelado à obrigatoriedade do ensino, possibilita o acesso a todos os cidadãos interessados a quaisquer níveis educacionais.

A obrigatoriedade, inclusive, deve ser ponderada à luz da insuficiência de instituições escolares e em consonância com o alcance da faixa etária conciliável com o trabalho em função da falta de visão dos pais ou responsáveis e das eventualidades econômicas.

Por último, a coeducação pressupõe uma escola unificada na qual a igualdade de oportunidades impera independentemente das diferenças de gênero. ${ }^{129}$ Além da defesa de uma concepção de escola única, pública, laica, obrigatória e gratuita, os idealizadores do "Manifesto" propunham o estabelecimento de um plano geral de educação pelo Estado.

Os autores do "Manifesto” acreditavam que haveria uma vinculação entre a filosofia de cada era e a educação que determinaria sua índole. Assim, "a educação nova não pode deixar de ser uma reação categórica, intencional e sistemática contra a velha estrutura do serviço educacional, artificial e verbalista, montada para uma concepção vencida"130

\footnotetext{
${ }^{128}$ Idem, p. 192.

${ }^{129}$ O Manifesto dos Pioneiros da Educação Nova (1932). Revista HISTEDBR On-line, Campinas, n. especial, p. 188-204, ago. 2006, p. 193-194.

${ }^{130}$ Idem, p. 191.
} 
Segundo eles, a finalidade da educação ultrapassa os limites das classes, pois sua verdadeira função social diz respeito a todos os grupos sociais que devem ter oportunidades iguais de acesso à educação.

A educação nova, fundada sobre o princípio da vinculação da escola com o meio social, visa atender aos interesses individuais e não de classes, pressupondo ideais como solidariedade, serviço social e cooperação. Por outro lado, a escola tradicional, estabelecida segundo uma concepção burguesa, decorrente da doutrina do individualismo libertário, tem mantido a sua autonomia isolada e estéril.

A Assembleia Nacional Constituinte, instalada em 1933, promulga a nova Constituição da República, inspirada na doutrina social democrática da Constituição de Weimar. Elege Getúlio Vargas presidente constitucional do Brasil, por quatro anos. Cria a Justiça do Trabalho e consagra o nacionalismo num capítulo admirável: Da Ordem Econômica e Social. Mas ao mesmo tempo, foi a maior vitória da LEC [Liga de Escolas Católicas] e do Centro Dom Vidal, com Alceu e Dom Leme à frente: colocou Deus no preâmbulo, instituiu o casamento indissolúvel, o ensino religioso facultativo, a pluralidade sindical, etc. [...] A fim de consolar os "progressistas" mineiros e separá-los dos "democratas" paulistas, Getúlio nomeia Gustavo Capanema para o Ministério da Educação e Saúde, cooptado como homem de confiança da Igreja contra o laicismo dos pioneiros da educação. ${ }^{131}$

O pioneirismo da Constituição de 1934, que serviu de modelo para a concepção de educação presente na Constituição de 1988, evidencia-se na significativa e inusitada dedicação de 17 artigos a essa temática, sendo 11 inseridos em um capítulo exclusivo sobre o tema (capítulo II, artigos. 148 a 158).

Preservava-se a estrutura do sistema educacional, na qual competia privativamente à União "traçar as diretrizes da educação nacional" (art. 5º, inciso XIV); "fixar o plano nacional de educação, compreensivo do ensino de todos os graus e ramos, comuns e especializados, organizar e manter" (artigo 150, alínea “a”); e “organizar e manter, nos Territórios, sistemas educativos apropriados aos mesmos” (artigo 150, alínea “c”).

Além disso, também estabeleceu que seria da competência da União “exercer ação supletiva, onde se faça necessária, por deficiência de iniciativa ou de recursos e estimular a obra educativa em todo o País, por meio de estudos, inquéritos, demonstrações e subvenções” (artigo 150, alínea “e”),

A Carta Magna de 1934 ainda preconizava a implementação do Plano

\footnotetext{
${ }^{131}$ RIBEIRO, D. Aos trancos e barrancos: como o Brasil deu no que deu. Rio de Janeiro: Guanabara, 1985, notas 775 e 778.
} 
Nacional de Educação, que previa a implantação do "ensino primário integral e gratuito e de freqüência obrigatória extensivo aos adultos" e a "tendência à gratuidade do ensino ulterior ao primário, a fim de o tornar mais acessível" (art. 150, parágrafo único, alíneas "a" e "b").

Além disso, apesar da consagração do princípio da laicidade do Estado, o ensino religioso foi prestigiado ao se mesclar ideias liberais com orientações conservadoras. Chegou-se, inclusive, a favorecer o ensino religioso "de freqüência facultativa [...] nas escolas públicas primárias, secundárias, profissionais e normais" (art. 153). Ressalte-se a ainda a ênfase desse dispositivo na frequência facultativa do ensino religioso e a exigência de ser ministrado segundo os princípios da confissão religiosa do educando.

Também cumpre salientar ainda outra inclinação conservadora no que se refere ao apoio incondicional e ilimitado ao ensino privado mediante a isenção de tributos a quaisquer "estabelecimentos particulares de educação gratuita primária ou profissional, oficialmente considerados idôneos" (art. 154).

Quanto ao financiamento da educação, pela primeira vez são definidas vinculações de receitas para ela. Caberia à União e aos municípios a aplicação de "nunca menos de dez por cento" e aos Estados e ao Distrito Federal "nunca menos de vinte por cento, da renda resultante dos impostos na manutenção e no desenvolvimento dos sistemas educativos" (art. 156).

Ademais, estabelece-se a reserva de uma parte dos patrimônios territoriais da União, dos Estados e do Distrito Federal para a formação dos respectivos fundos de educação (art. 157).

Além disso, havia outros pontos de destaque no texto tais como: o Plano Nacional de Educação preconizando "liberdade de ensino em todos os graus e ramos, observadas as prescrições da legislação federal e da estadual” (artigo 150, parágrafo único, alínea “c”) e "reconhecimento dos estabelecimentos particulares de ensino somente quando assegurarem. a seus professores a estabilidade, enquanto bem servirem, e uma remuneração condigna” (artigo 150, parágrafo único, alínea “f”).

Destaca-se a oferta do ensino em língua nacional (art. 150, alínea “d”); a exigência que "toda empresa industrial ou agrícola, fora dos centros escolares, e 
onde trabalharem mais de cinqüenta pessoas, perfazendo estas e os seus filhos, pelo menos, dez analfabetos, será obrigada a lhes proporcionar ensino primário gratuito” (art. 139); a vedação do alistamento eleitoral dos analfabetos (art. 108).

Outrossim, vale destacar ainda que, objetivando-se o favorecimento da principal categoria de profissionais da educação, o texto constitucional contava com um dispositivo concernente à isenção de impostos para professores (artigo 113, inciso 36) e outro que exigia a realização de concurso público para ingresso na carreira do magistério oficial (artigo 158). ${ }^{132}$

Apesar do tom autoritário da era Vargas, houve mudanças positivas nesse período da história do país como a criação do Ministério do Trabalho, Indústria e Comércio (1931) e a Consolidação das Leis do Trabalho (1943).

No âmbito educacional, sob o regime do Estado Novo promoveu-se o resgate da centralização das reformas educacionais em contraposição da autonomia dos Estados verificada nos anos anteriores em virtude dos movimentos reformistas. Durante a longa gestão de Gustavo Capanema no Ministério da Educação, conceberam-se as Leis Orgânicas de Ensino, integradas por seis decretos-leis efetivados de 1942 a $1946 .^{133}$

Por sua vez, inspirada pelo constitucionalismo típico de regimes fascistas europeus $^{134}$, a Constituição dos Estados Unidos do Brasil, de 10 de novembro de 1937, possuía inclinação antagônica ao teor liberal da Constituição de 1934.

Entretanto, vale ressaltar que, segundo Karl Loewenstein, o regime do Estado Novo não consistiu na reprodução literal do fascismo, pois o Brasil sob o regime de Getúlio Vargas definitivamente não se encaixava no padrão estereotipado da anatomia da autocracia fascista vista na Alemanha, Rússia, Itália, Espanha e em outros lugares ${ }^{135}$. Diferentemente dos regimes fascistas europeus, o Brasil do período do Estado Novo não era um estado de partido único, mas sim apartidário. Isto é, não havia qualquer partido controlado pelo governo, pois inclusive não havia partido algum. Além disso, se não foi com a aprovação da

\footnotetext{
${ }^{132}$ VIEIRA, S. L. A educação nas constituições brasileiras: texto e contexto. R. Bras. Est. Pedag. Brasília, v. 88, n. 219, p. 291-309, maio/ago. 2007, p. 297.

${ }^{133}$ Idem, p. 297-298.

${ }^{134}$ Idem, p. 298.

${ }^{135}$ [...] With local variations all modern dictatorships have followed this "classic" pattern, as can be seen from the anatomy of autocracy in Germany, Russia, Italy, Spain, and elsewhere.[...] (LOEWENSTEIN, K. Brazil under Vargas. New York: Macmillan, 1942, p. 133).
} 
maioria da nação, pelo menos com a sua aquiescência esse regime chegou ao poder. ${ }^{136}$ Assim, nesses, e em muitos outros aspectos, a ditadura Vargas era claramente diferente dos estados fascistas para os quais a manutenção do partido único fascista era o requisito primordial de sua existência. ${ }^{137}$ Indubitavelmente, é incontroverso que se tratava de um Estado autoritário ou uma ditadura, pois a autoridade do governo na formação e execução das políticas nacionais prescindia da participação organizada do povo através de métodos institucionalizados. ${ }^{138}$

Como exemplo disso, estabelecia o inciso IX do artigo 15: "Compete privativamente à União fixar as bases e determinar os quadros da educação nacional, traçando as diretrizes a que deve obedecer a formação física, intelectual e moral da infância e da juventude”. 139

É digno de destaque o texto do artigo 128, que indica uma priorização da exploração do ensino pela livre iniciativa em detrimento do dever direto do Estado para com a educação. Neste mesmo diapasão, o teor do artigo 129 impõe ao Poder Público um papel secundário e compensatório na disponibilização escolar destinada à "infância e à juventude, a que faltarem os recursos necessários à educação em instituições particulares”.

Além disso, ao arrepio do ideário liberal-democrático consagrado pelos revolucionários franceses que lutaram pelo fim da dualidade educacional, o mesmo artigo 129 previa um discriminador "ensino pré-vocacional e profissional destinado às classes menos favorecidas" entendido como "o primeiro dever do Estado” no que tange à educação.

Tendo escolhido o ensino vocacional e profissional como sua prioridade, salta aos olhos a omissão em relação às demais modalidades de ensino. A atenção da política educacional no Estado Novo voltava-se totalmente para o ensino profissional, que seria priorizado nas reformas promovidas pelo ministro da educação Gustavo Capanema.

A perspectiva estado-novista da educação pública reservada aos que não

\footnotetext{
${ }^{136}$ LOEWENSTEIN, K. Brazil under Vargas. New York: Macmillan, 1942, p. 133-134.

${ }^{137}$ Idem, p. 147.

${ }^{138}$ LOEWENSTEIN, K. Brazil under Vargas. New York: Macmillan, 1942, p. 121.

${ }^{139}$ BRASIL. Constituição (1937). Constituição dos Estados Unidos do Brasil, promulgada em 10 de novembro de 1937. <http://www.planalto.gov.br/ccivil_03/constituicao/constituicao37.htm>. Acesso em: 2 dez. 2013.
} 
podiam pagar o ensino privado revela preconceito contra a escola pública gratuita. À ênfase na total gratuidade do ensino inserida na Constituição de 1934 a Carta de 1937 se contrapôs um enfoque segregador, excludente e até mesmo constrangedor. Isto é, embora preconizasse o ensino primário obrigatório e gratuito, o artigo 130 revela a natureza parcial dessa gratuidade.

Ao prever "o dever de solidariedade dos menos para com os mais necessitados", previa que, no ato da matrícula, seria "exigida aos que não alegarem, ou notoriamente não puderem alegar escassez de recursos, uma contribuição módica e mensal para a caixa escolar”.

No que tange ao ensino religioso, o artigo 133 caracterizou-se pelo seu viés conservador em virtude da ambiguidade do seu texto. Consequentemente, o caráter facultativo dessa modalidade de ensino acabou se tornando obrigatório, devido ao predomínio da Igreja Católica e a grande quantidade de instituições escolares confessionais no país.

Após a queda do Estado Novo de Vargas no final de 1945, o então presidente da República, general Eurico Gaspar Dutra promulgou a Constituição dos Estados Unidos do Brasil em 18 de setembro de 1946, fundamentada em princípios liberais e democráticos. Restaura-se o estado de direito e a autonomia federativa. Este período também ficou marcado pela intervenção em sindicatos, pela decretação da ilegalidade do Partido Comunista Brasileiro e pelo crescimento econômico e industrial. ${ }^{140}$

Na década de 1940, as reformas educacionais foram marcadas pelo advento das leis orgânicas do ensino: Lei Orgânica do Ensino Industrial (Decreto-Lei nº 4.073/42), Lei Orgânica do Ensino Secundário (Decreto-Lei $n^{\circ}$ 4.244/42) e Lei Orgânica do Ensino Comercial (Decreto-Lei ${ }^{0}$ 6.141/43). Vale destacar ainda que o Serviço Nacional de Aprendizagem Industrial (SENAI) e o Serviço Nacional de Aprendizagem Comercial (SENAC) foram criados nesta década, respectivamente pelo Decreto-Lei no 4.048/42 e Decretos-Lei n 8.621/46 e nº 8.622/46.

Ademais, a Reforma Capanema, além de manter também acentuou o dualismo do sistema educacional que a proposta educacional revolucionária

\footnotetext{
${ }^{140}$ VIEIRA, S. L. A educação nas constituições brasileiras: texto e contexto. R. Bras. Est. Pedag. Brasília, v. 88, n. 219, p. 291-309, maio/ago. 2007, p. 299.
} 
francesa buscou eliminar, ao separar a educação escolar das classes dirigentes daquela destinada às classes operárias. As diretrizes desta reforma orientaram a política educacional até o advento da LDB n 4.024/61. ${ }^{141}$

A Carta Magna promulgada em 1946 segue a tônica da Constituição de 1934 preconizando a competência da União para "legislar sobre as diretrizes e bases da educação nacional" (art. 5 $5^{\circ}$ XV).

Restaurando o direito de todos à educação, estabeleceu-se que "o ensino dos diferentes ramos será ministrado pelos Poderes Públicos e é livre à iniciativa particular, respeitadas as leis que o regulem" (art. 167) e "o ensino primário oficial é gratuito para todos: o ensino oficial ulterior ao primário sê-lo-á para quantos provarem falta ou insuficiência de recursos" (art. 168, II). Contudo, não havia garantia de laicidade, apesar da determinação que o ensino religioso fosse ministrado segundo as confissões de cada aluno.

Nota-se uma inovação na porcentagem de recursos vinculados para a educação, pois a União deveria aplicar nunca menos de 10\% e Estados, Municípios e Distrito Federal, nunca menos de 20\% das receitas resultantes de impostos na "manutenção e desenvolvimento do ensino" (art. 169).

Ademais, a União deveria contribuir para o desenvolvimento dos sistemas educativos, oferecendo "auxílio pecuniário", que, no caso do ensino primário, "provirá do respectivo Fundo Nacional" (art. 171, parágrafo único).

Além disso, os Estados e o Distrito Federal deveriam organizar seus "sistemas de ensino" (art. 171), cabendo à União organizar o "sistema federal de ensino e o dos Territórios, tendo este um caráter supletivo, estendendo-se a todo o País nos estritos limites das deficiências locais" (art. 170).

Em pleno regime militar, a Constituição de 1967 revelava interesses políticos evidenciados em Cartas anteriores, principalmente àqueles associados ao ensino privado e à "liberdade de ensino". Mantendo a tendência do texto de 1946 (art. 5 XV), a Carta de 1967 previa a competência da União para legislar sobre diretrizes e bases da educação nacional (art. 8, XVII, "q"), assim como atribuições concernentes aos planos nacionais de educação (art. 8 , XIV).

\footnotetext{
${ }^{141}$ Idem, p. 299-300.
} 
Princípios anteriores consagrados em outras Constituições são retomados, tais como: o ensino primário em língua nacional (Constituição de 1946, art. 168, I, e Constituição de 1967, art. 176, $\S 3^{\circ}$, I), a obrigatoriedade e a gratuidade do ensino primário (Constituição de 1946, art. 168, I e II, e Constituição de 1967, art. 176, § $\left.3^{\circ}, \mathrm{II}\right)$, o ensino religioso, de matrícula facultativa como "disciplina dos horários normais das escolas oficiais de grau primário e médio (Constituição de 1946, art. 168, § 5º e Constituição de 1967, art. 176, § 3º, V).

À concepção de educação como "direito de todos", já inserida no texto de 1946 (art. 166), a Constituição de 1967 acrescentou "o dever do Estado" (art. 176). No mesmo diapasão da Carta de 1946 (art. 167), a Constituição de 1967 estabelecia que o ensino fosse "ministrado nos diferentes graus pelos poderes públicos" (art. 176, § $1^{\circ}$ ).

Embora ambas preconizassem que a educação fosse "livre à iniciativa particular", percebe-se, porém, uma relevante distinção entre elas. O texto de 1946 adverte que deveriam ser "respeitadas as leis que o regulem" (art. 167), enquanto a Constituição de 1967 investe claramente no âmbito do subsídio ao ensino privado, já que este "merecerá amparo técnico e financeiro dos Poderes Públicos, inclusive mediante bolsas de estudo" (art. 176, § $2^{\circ}$ ).

Além disso, o texto inova ao admitir a "intervenção do Estado no município" que não aplicar "no ensino primário, em cada ano, de vinte por cento, pelo menos da receita tributária municipal" (art. 15). O retrocesso fica por conta da desvinculação dos recursos para a educação.

Vale destacar ainda os acordos entre o Ministério da Educação e Cultura e a United States Agency for International Development (USAID) celebrados e implementados entre os anos de 1964 e 1968, que geraram as reformas educacionais promovidas pelo regime militar. Os programas promovidos pela agência norte-americana incluíam empréstimos financeiros, doação de equipamentos, concessões de bolsas de estudo e patrocínio da vinda de especialistas norte-americanos para assessorar técnicos do MEC.

Tais convênios oficialmente previam a cooperação técnica entre o MEC e a USAID, mas tinham como real objetivo a promoção do alinhamento ideológico do sistema educacional brasileiro com os interesses dos EUA. Assim, a USAID 
passou a atuar no treinamento de órgãos e pessoal. Inclusive, seus opositores os consideram "acordos pelos quais os governos Castelo Branco e Costa e Silva entregaram o planejamento do ensino brasileiro aos Estados Unidos". ${ }^{142}$ Seus antagonistas também afirmavam que “a importação de um planejamento ideológico, não apenas condiciona, como determina"143 0 futuro do país.

Além disso, visando a aplicação das reformas no ensino, o regime militar promoveu medidas repressivas direcionadas aos movimentos docente e estudantil associadas a tais propostas de modernização da educação nacional. Destacam-se o Decreto $n^{0}$ 228/67, que restringiu a criação de “organizações estudantis ao âmbito estrito de cada universidade; o Decreto $n^{0}$ 477/69, que impôs severas punições aos estudantes, professores ou funcionários que desenvolvessem atividades consideradas hostis ao regime militar”. 144

Inclusive, Darcy Ribeiro também denunciou a doutrinação norte-americana com propósitos de colonização cultural que visava suprimir a autonomia educacional nacional ao partir do pressuposto de que o Brasil deve se resignar à uma postura subalterna e periférica. Assim, ele se opôs à ingerência de órgãos internacionais no tipo e na natureza da educação a ser ministrada no Brasil. ${ }^{145}$

Quando se pensa na generosidade de fundações, banqueiros e governos estrangeiros, a oferecer empréstimos dadivosos e a patrocinar pesquisas; a mandar especialistas solícitos para prodigalizar conselhos e promover conferências interamericanas [...] cumpre indagar: que há por trás de tudo isto? E, mesmo não sendo possível afirmar que toda a ajuda e todas as intenções sejam intrinsecamente inconvenientes, é indispensável afirmar que elas têm conteúdos políticos não explícitos.

A única forma de resposta a esta política intencional de colonização cultural é fazer a análise séria de toda sua fachada generosa, tratando de desnudar seus propósitos ocultos $[\ldots]$

Darcy percebia nesse modelo de desenvolvimento educacional a influência de “forças conservadoras” que priorizavam "progressos reflexos” "sempre de modo a perpetuar a estrutura de poder e as camadas sociais por ela privilegiadas, embora ao preço de condenar as nações latino-americanas a perpetuarem-se no

\footnotetext{
${ }^{142}$ ALVES, M. M. O Beabá dos MEC-USAID. Rio de Janeiro: Gernasa, 1968, p. 33.

${ }^{143}$ Idem, p. 27.

${ }^{144}$ MARTINS, C. B. A reforma universitária de 1968 e a reabertura para o ensino superior privado no Brasil. In: Educ. Soc., Campinas, vol. 30, n. 106, p. 15-35, jan./abr. 2009, p. 18.

${ }^{145}$ RIBEIRO, D. A universidade necessária. 5. ed. Rio de Janeiro: Paz e Terra, 1991, p. 38.
} 
papel periférico de povos dependentes e espoliados, até agora desempenhado.”146

Para ele, a política de desenvolvimento autônomo demanda “o máximo de lucidez e de intencionalidade" em relação à sociedade brasileira, "mediante cuidadoso diagnóstico de seus problemas, de um delineamento rigoroso de seu crescimento e de uma escolha estratégica de objetivos, necessariamente opostos aos da modernização reflexa."147 Logo, ao invés da dependência de modelos educacionais alheios, "só por este caminho poderemos alcançar, em algum tempo previsível, aquele grau de maturidade científica que nos permita alcançar um desenvolvimento autônomo da cultura nacional.”148

\section{2 \\ o Cenário Político dos Debates e Embates em Torno do Teor da Seção da Educação nas Comissões da Constituinte}

Inicialmente, com vistas a dirimir quaisquer dúvidas quanto ao liame entre o conteúdo exposto no primeiro capítulo e este, cumpre ressaltar que, em $1^{0}$ de fevereiro de 1987, o Ministro José Carlos Moreira Alves, então o Presidente do Supremo Tribunal Federal, no seu discurso na sessão de instalação da Assembleia Nacional Constituinte de 1987-1988 ao lecionar sobre a evolução histórica do constitucionalismo, reconhece a conexão ou o nexo entre o legado constitucional originário transmitido pela Revolução Francesa e a estrutura constitucional brasileira contemporânea.

Além disso, inclusive pode-se nitidamente constatar, nas próprias palavras do referido ministro, o destaque à pertinência ou relevância dessa herança deixada pelo movimento revolucionário francês, em virtude das conquistas alcançadas, sobretudo na sua fase marcada pela supremacia jacobina, para a formação da atual concepção brasileira do direito fundamental à educação.

A Declaração dos Direitos do Homem e do Cidadão somente em agosto de 1789 foi aprovada pela Assembleia Nacional francesa. É o primeiro texto positivo em que propriamente se enumeram os direitos do individuo. [...] As várias Constituições que se elaboraram dessa época até o fim da primeira guerra mundial têm conteúdo eminentemente político, e são, em verdade, instrumentos do liberalismo, cujo espírito está bem caracterizado no célebre artigo 16 da Declaração dos Direitos do Homem e do Cidadão: "Toda sociedade em que não

\footnotetext{
${ }^{146}$ Idem, p. 27.

${ }^{147}$ Idem, p. 26.

${ }^{148}$ Idem, p. 38.
} 
se assegura a garantia dos direitos; nem se determina a separação dos Poderes, não tem Constituição". Ao longo desse período, não prospera a inovação da Constituição francesa dos Jacobinos, de junho de 1793, no sentido de se inserirem, no texto constitucional, direitos sociais, como o direito ao trabalho ou o direito à educação. ${ }^{149}$

Ademais, vale assinalar também a mobilização dos educadores para assegurar a inserção das suas contribuições e proposições no texto da nova Constituição que seria promulgada em 1988. Antes da instalação da Constituinte, a IV Conferência Brasileira de Educação, em agosto de 1986, cujo tema central era "A educação e a constituinte", aprovou "a Carta de Goiânia" com propostas dos docentes para a seção concernente à educação. ${ }^{150}$

No processo de formulação da Constituição Federal de 1988, o tema educação primeiramente foi debatido e submetido a deliberações no âmbito da Subcomissão de Educação, Cultura e Esportes. Em seguida, prosseguiram as discussões e votações da Comissão da Família, Educação, Cultura, Esportes, da Ciência e Tecnologia e da Comunicação, depois a Comissão de Sistematização e as votações em plenário.

Inegavelmente, o processo legislativo realizado pela Assembleia Nacional Constituinte ao longo dos anos de 1987 e 1988 foi marcado por tensões entre correntes sociopolíticas hegemônicas e contra-hegemônicas que objetivavam promover o seus respectivos projetos e agendas neste período de transição entre o regime autoritário para a democracia. Lúcia Neves destaca esse tom de tentativa de conciliar vertentes com interesses antagônicos ao longo do processo de consolidação do direito fundamental à educação.

Conservação e mudança, nos seus diversos matizes, disputavam a manutenção de privilégios ou a obtenção e novas conquistas. O resultado, como não poderia deixar de ser no quadro de uma transição nitidamente conciliadora, foi simultaneamente conservação e mudança. ${ }^{151}$

Inclusive, antes mesmo da instalação da Constituinte de 1987-1988, já podia-se notar a existência de dois projetos antagônicos: um de caráter conservador e outro de natureza progressista. O primeiro contava com patrocínio

\footnotetext{
${ }^{149}$ BRASIL. Ata da Assembleia Nacional Constituinte de 2 de fevereiro de 1987. Diário da Assembleia Nacional Constituinte. Ano XLII, n. 001. Brasília, p. 3-4.

${ }^{150}$ SAVIANI, D. A nova lei da educação: trajetória, limites e perspectivas. 11. ed. Campinas: Autores Associados, 2008, p. 35.

${ }^{151}$ NEVES, L. M. Educação e política no Brasil de hoje. 2. ed. São Paulo: Cortez, 1999, p. 99.
} 
do Poder Executivo e defendia os interesses dos setores dominantes, pois o Congresso Nacional da época já “era - e continua a ser - a casa das oligarquias mais atrasadas deste país”" ${ }^{152}$. Contudo, alguns “acidentes de percurso”, como a índole da Comissão de Notáveis Arinos, o perfil neófito da Constituinte resultante das eleições de 1986 e as manobras regimentais de Mário Covas no âmbito das Subcomissões, culminaram na alteração da primazia de forças conservadoras em favor da minoria progressista. ${ }^{153}$

Deste modo, pode-se concluir que, indiscutivelmente, os trabalhos realizados pela Subcomissão de Educação, Cultura e Esportes ficaram marcados pelo embate entre correntes progressistas e conservadoras antagônicas que contrapunham, respectivamente, interesses públicos e privados.

Além disso, a participação de grupos e entidades ligadas à matéria educacional foi intensa e contou com a apresentação de propostas e questionamentos aos constituintes. Dos embates ocorridos e das pressões exercidas no seio da Subcomissão de Educação, Cultura e Esportes na Constituinte resultaram dispositivos que "não sofreram grandes alterações na Comissão de Sistematização”.

Inclusive, cumpre salientar que, pela primeira vez na história do constitucionalismo nacional, dedicou-se à ordem social um tratamento diferenciado que culminou na atribuição de um título independente da ordem econômica. Inclusive, neste ponto torna-se oportuno assinalar a configuração de forças políticas e tendências ideológicas no seio da Comissão VIII, da Família, da Educação, Cultura e Esportes, da Ciência e Tecnologia e da Comunicação:

[...] a Comissão VIII foi instalada com 62 membros, dos quais 23 pertenciam aos partidos de direita (15 do PFL, 4 do PDS, 3 do PTB, e 1 do PL) e 5 aos partidos de esquerda ( 3 do PDT e 2 do PT). Dos 34 titulares do PMDB, 17 podem ser situados no campo conservador, 12 no campo progressista e 5 podem ser considerados moderados. Dos 34 suplentes, 12 podem ser classificados como conservadores, 10 como progressistas e 11 como moderados. Também aqui a vantagem do bloco conservador sobre o progressista era ampla: 40x17, inalcançável ainda que os titulares moderados do PMDB se alinhassem todos com os progressistas, embora matematicamente possível (porém politicamente improvável) se a esta hipótese se

\footnotetext{
${ }^{152}$ PILATTI, A. Comentários ao texto de Maria Francisca Pinheiro. In: FÁVERO, O. (Org.) A educação nas constituintes brasileiras 1823-1988. Campinas, SP: Autores Associados, 1996, p. 294.

${ }^{153}$ Idem, p. 294-297.
} 
acrescentasse a substituição de titulares conservadores por suplentes progressistas ou alinhados. ${ }^{154}$

Vale assinalar o testemunho de Adriano Pilatti, então assessor parlamentar da Câmara dos Deputados junto à Assembleia Nacional Constituinte de 19871988. Ele destaca que o compartilhamento dos cargos em função do "grande acordo” defrontou-se com resistências de alas conservadoras do PMDB, com suporte ocasional de constituintes de tendência conservadora de outros partidos, “e também (ao menos num primeiro momento) de progressistas do PMDB e de outros partidos, o que parecia refletir o caráter centralizado da celebração do acordo PMDB-PFL”. 155

Ademais, vale ressaltar ainda que na $194^{\mathrm{a}}$ sessão da Assembleia Nacional Constituinte em 4 de fevereiro de 1988, o constituinte Átila Lira (PFL - PI) declarou que:

O Projeto de Constituição da Comissão de Sistematização, na parte relativa à Educação, no capítulo III, arts. 240 a 247, expressa os aspectos debatidos pela sociedade, através de associações de pais, associações de magistério e, a Subcomissão de Educação, da qual fizemos parte. As mudanças essenciais compreendem os princípios de uma escola pública e gratuita: o plano de carreira para o magistério público: a ampliação da verba pública de $13 \%$ para $18 \%$; a destinação de verbas públicas com prioridade para a escola pública, podendo também atender às escolas confessionais e comunitárias sem fins lucrativos; e o direito do magistério público de escolher os dirigentes das escolas públicas, federais, estaduais e municipais. ${ }^{156}$

A sessão realizada em 22 de abril de 1987 ficou marcada pela discussão sobre a destinação de recursos públicos para a promoção da educação. Naquela ocasião, os constituintes Octávio Elísio e Florestan Fernandes destacaram-se na defesa dos interesses da escola pública, pugnando pela garantia da exclusividade da verba pública para financiamento da educação pública e não para a indústria do ensino e o ensino confessional.

$\mathrm{Na}$ ata da $13^{\mathrm{a}}$ Reunião Ordinária da Subcomissão dos Direitos Políticos, Direitos Coletivos e Garantias, de 14 de maio de 1987, percebe-se que o Relator

\footnotetext{
${ }^{154}$ PILATTI, A. A constituinte de 1987-1988: progressistas, conservadores, ordem econômica e regras do jogo. Rio de Janeiro: Lumen Juris, 2008, p. 62-63.

${ }^{155}$ Idem, p. 67.

${ }^{156}$ BRASIL. Ata da $194^{a}$ Sessão da Assembleia Nacional Constituinte em 4 de fevereiro de 1988.
}

Diário da Assembleia Nacional Constituinte de 5 de fevereiro de 1987, p. 6961. 
Lysâneas Maciel (PDT-RJ), ao apresentar seu relatório e tratar, entre outros temas sobre o princípio da reserva do possível, paradoxalmente assinala que se

[...] o Estado demonstrar comprovadamente a impossibilidade da prestação por falta ou insuficiência de recursos financeiros [...] é assegurado o direito ao saneamento básico, à saúde, à educação, ao transporte, todos aqueles direitos de que o cidadão comum deva ser o titular. Mas como cumprir isso? Via uma mera declaração a ser estabelecida no texto constitucional? Muitas vezes, Srs. Constituintes, estabelecer uma norma no texto constitucional implica torná-la mais distante do direito a ser protegido. ${ }^{157}$

$\mathrm{Na}$ ata da $2^{\mathrm{a}}$ Reunião Ordinária da Comissão VIII (que não conseguiu concluir seus trabalhos, ficando a tarefa a cargo do Relator da Comissão de Sistematização, que o apresentou juntamente com o Anteprojeto de Constituição), em 25 de maio de 1987, registrou-se: "Informou ainda, a Presidência que, em sendo deliberado pelos Senhores membros da Comissão, poderão ser ouvidos alguns representantes de segmentos sociais durante audiências públicas." 158

Ressalte-se que quando a Comissão VII termina seu prazo, o relator Artur da Távola afirma que não haveria projeto pois não havia acordo devido a alguns pontos que não haviam sido superados na área de educação em função do lobby do setor privado capitaneado pelo constituinte conservador Álvaro Valle. ${ }^{159}$

Já na $5{ }^{\mathrm{a}}$ Reunião Ordinária dessa mesma Comissão, realizada em 28 de maio de 1987, "o Constituinte Octávio Elísio salientou que o anteprojeto da Subcomissão se originou do esforço coletivo de todos os membros em defender a Educação, conseguindo alguns avanços significativos, citando o artigo terceiro, inciso segundo e parágrafo único. Comentou, ainda, os artigos sétimo, oitavo, décimo e décimo quarto, considerando que a educação pública, gratuita e de boa qualidade, é um compromisso de todos." 160

Na reunião de 28 de maio de 1987, o constituinte João Calmon assinalou que, como relator da Subcomissão da Educação, Cultura e Esportes, tinha o dever de realçar alguns pontos de maior relevância no anteprojeto constitucional.

\footnotetext{
${ }^{157}$ BRASIL. Ata da $13^{\text {a }}$ Reunião Ordinária da Subcomissão dos Direitos Políticos, dos Direitos Coletivos e Garantias realizada em 14 de maio de 1987. Diário da Assembleia Nacional Constituinte de 8 de julho de 1987. Ano I - Suplemento ao nº 90. Brasília, 1987, p. 26.

${ }^{158}$ BRASIL. Ata da $2^{\text {a }}$ Reunião Ordinária da Comissão VIII. Diário da Assembleia Nacional Constituinte de 25 de maio de 1987, p. 8.

${ }^{159}$ PILATTI, A. A constituinte de 1987-1988: progressistas, conservadores, ordem econômica e regras do jogo. Rio de Janeiro: Lumen Juris, 2008, p. 138.

${ }^{160}$ BRASIL. Ata da $5^{a}$ Reunião Ordinária da Comissão VIII. Diário da Assembleia Nacional Constituinte de 28 de maio de 1987, p. 41.
} 
A começar do art. $2^{\circ} \S 5^{\circ}$ consagramos não apenas a garantia de ensino fundamental para todos, mas também, por iniciativa do nobre Constituinte Louremberg Nunes Rocha, a destinação obrigatória de nunca menos de $50 \%$ das verbas para a educação, para o ensino fundamental para todos. [...] Outro ponto alto do projeto da Subcomissão da Educação Cultura e Esportes foi a garantia, pela primeira vez nas constituições brasileiras, da gratuidade de ensino público em todos os níveis. Hipocritamente todas as constituições brasileiras, sem nenhuma exceção, garantiam a gratuidade apenas do Primeiro Grau e determinavam que no Segundo e Terceiro graus, quem tivesse capacidade de pagar, seria obrigado a pagar. Quem não tivesse, pediria bolsas de estudo, restituíveis, de acordo com os critérios de uma lei,que jamais foi aprovada em nosso País. ${ }^{161}$

Calmon destacou a relevância da decisão da Comissão sobre a obrigatoriedade de os Estados e Municípios destinarem, além dos 25\% sobre a sua receita de impostos, mais 25\% sobre as transferências do Governo federal para os Estados. As transferências do governo estadual para os Municípios também reapresentaram uma considerável conquista. Em seguida, ele afirmou:

[...] nutro a esperança de que, pelo menos, na pior das hipóteses, a Constituição abra, como o foi pelo Congresso Nacional, uma exceção para a educação, já que o Brasil, apesar de ser a oitava economia do mundo, está colocado em $80^{\circ}$. lugar, portanto, abaixo de 79 países, em dispêndios públicos com educação, em relação ao Produto Interno Bruto. ${ }^{162}$

O supramencionado constituinte ainda acrescentou outra conquista da subcomissão que deveria ser mantida na Comissão Temática, na Comissão de Sistematização e no Plenário da Constituinte. Seria o caso do art. 13, que dispõe sobre o desenvolvimento da educação, da cultura, da ciência e da pesquisa em geral mediante amplos incentivos fiscais. Além disso, ele ainda enfatizou as conquistas e avanços resultantes do trabalho da Comissão.

Esse é outro passo muito significativo em favor da educação porque, além do percentual de $18 \%$ sobre a receita de impostos federais para a educação, criamos uma outra possibilidade; incentivos fiscais, à semelhança do que já existe com a lei Sarney, que destina também incentivos fiscais apenas para a cultura. Ampliamos para a área da cultura, educação, ciência e pesquisa em geral. Outro artigo que consideramos uma conquista muito significativa da nossa subcomissão, e que é de iniciativa do mestre dos mestres, o nobre Constituinte, professor Florestan Fernandes, é o art. 15, cujo texto é o seguinte: "Lei complementar criará o Conselho Nacional de Desenvolvimento da Educação, de constituição democrática, com autonomia administrativa e financeira, e responsabilidade para estabelecer programas e políticas, a serem realizadas pelo plano nacional de educação. ${ }^{163}$

\footnotetext{
${ }^{161}$ Idem, p. 42.

${ }^{162}$ Idem, p. 42-43.

${ }^{163}$ BRASIL. Ata da $5^{\mathrm{a}}$ Reunião Ordinária da Comissão VIII. Diário da Assembleia Nacional

Constituinte de 28 de maio de 1987, p. 43.
} 
O relator enfatizou ainda a priorização do financiamento à educação pública ao destacar o art. 11: “A União aplicará anualmente, nunca menos de $18 \%$, e os Estados, o Distrito Federal e os Municípios, 25\%, no mínimo, da receita resultante em impostos, inclusive os provenientes de transferências, na manutenção e desenvolvimento do ensino.” ${ }^{\text {"164 }}$ Alegando que no texto sugerido pelo Presidente da Subcomissão, a parte final receberia a adição do adjetivo “público”, ele afirma:

[...] enquanto que no meu texto, que repetia Ipse Literis, os textos das constituições de 1934 e 1946, se referia apenas à manutenção e desenvolvimento do ensino, sem especificar público ou privado. Surgiu, portanto, um conflito entre dois artigos; porque o art. $7^{\circ}$ do anteprojeto do Relator, tinha o seguinte texto: "O ensino é livre à iniciativa privada, observadas as disposições legais. ${ }^{165}$

Tratando do financiamento da educação, ele registra que a Subcomissão aprovou uma emenda da constituinte Abigail Feitosa, acrescentando mais palavras ao artigo $7^{\circ}$. Ele ressaltou que este artigo conflita com o artigo 11, que dispõe sobre a destinação de dinheiro público para o ensino em geral, sem exclusividade para o ensino público.

Além disso, ele lembrou que, através de um acordo de cavalheiros, o artigo 15 (que previa a transferência de verbas públicas a instituições educacionais privadas prestadoras de relevantes serviços públicos) não foi votado, porque a Subcomissão, através de acordo na Comissão Temática ou Comissão de Sistematização o introduziu nas disposições transitórias. ${ }^{166}$

Por outro lado, discorrendo ainda em relação à exclusividade dos recursos públicos para a educação o constituinte Louremberg Nunes Rocha enfatizou a relevância das escolas religiosas e filantrópicas, que prestam relevantes serviços gratuitos em regiões inóspitas.

Portanto, mediante negociações com os constituintes Octávio Elísio e Hermes Zanetti, estabeleceu-se a exclusividade das verbas públicas para a escola particular que garantisse também a inclusão dessas escolas comunitárias e religiosas. Calmon assinalou ainda que Rocha decidiu vincular obrigatoriamente

\footnotetext{
${ }^{164}$ Idem, p. 42-43.

${ }^{165}$ Idem, p. 43.

${ }^{166}$ Idem, p. 43-44.
} 
$50 \%$ dos recursos destinados à educação ao ensino fundamental, previsto como um direito do ser humano na Carta Universal dos Direitos do Homem. ${ }^{167}$

O Sr. Relator Artur da Távola solicitou que Rocha discorresse sobre a figura do mandato de injunção, previsto no parágrafo único do art. $3^{\circ}$ ("O acesso de todos os brasileiros à educação obrigatória e gratuita é direito público subjetivo, acionável contra o Estado, mediante mandado de injunção"). ${ }^{168}$

Então o constituinte supracitado explicou que o mandato de injunção vinha para obrigar o organismo público que cumpra aquilo que a lei determina, ou seja, aplicar determinado percentual de recursos na educação. Ele pode ser acionado por qualquer cidadão visando obrigar os entes públicos a cumprirem com aquilo que a Constituição lhes determina. ${ }^{169}$

Rocha ressaltou ainda o imperativo da aplicação anual vinculada da receita resultante de impostos na manutenção e desenvolvimento do ensino. Apesar de ouvir que, tecnicamente, a vinculação não seria adequada, porque afrontaria a técnica de planejamento, ele assegurou que, "tem que ser uma bandeira desta comissão a luta para garantir a vinculação, no caso específico, à educação; sem isso não conseguiremos de maneira alguma dar esse salto tão necessário a reerguer socialmente o Brasil”. ${ }^{170}$

Vale salientar a atuação do constituinte Florestan Fernandes, que defendia o acesso à educação pública, igualitária e de qualidade como uma das condições básicas para a transformação da realidade social. Cabe aqui uma alusão à sua integridade e coerência deste signatário do "Manifesto dos Educadores Democratas em Defesa do Ensino Público" (1959), e que Comissão de Educação defendeu veementemente o projeto de educação de interesse das classes operárias. Segundo ele, o sistema educacional deve objetivar a formação de uma consciência cívica para as classes hegemônicas e de consciência crítica para o proletariado. ${ }^{171}$

A relevância que Florestan atribuiu à educação refletiu-se no fato de que este foi o tema que recebeu maior número de emendas de sua autoria. Para ele a

\footnotetext{
${ }^{167}$ BRASIL. Ata da $5{ }^{\text {a }}$ Reunião Ordinária da Comissão VIII. Diário da Assembleia Nacional Constituinte de 28 de maio de 1987, p. 44.

${ }^{168}$ Idem, p. 44.

${ }^{169}$ Idem, p. 44.

${ }^{170}$ Idem, p. 45.

${ }^{171}$ NEVES, M. A. Florestan Fernandes: sociologia e política pela autonomia da nação. Instituto de Pesquisas Universitárias do Rio de Janeiro: Rio de Janeiro, 2009, p. 53.
} 
“educação é o mais grave dilema social brasileiro. A sua falta prejudica da mesma forma que a fome e a miséria, ou até mais, pois priva os famintos e miseráveis dos meios que os possibilitem a tomar consciência de sua condição, dos meios de

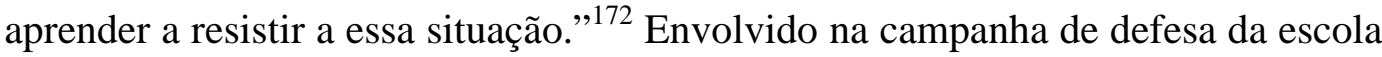
pública, destacou-se na Assembleia Nacional Constituinte em 1987-1988, como "o lutador incansável na defesa da escola pública, gratuita e laica."173

No Congresso, lutou para que o direito à educação pública fosse assegurado em lei para todos e esbarrou nos interesses de outros grupos, que foram somando forças no decorrer do embate: a igreja e o empresariado do ensino. Além disso, mesmo em meio ao processo de redemocratização do país, os militares ainda exerciam forte influência na tomada de decisões, o que representou mais uma barreira a ser superada contra o conservadorismo. ${ }^{174}$

Ao longo de todo o período de atuação da Assembleia Nacional Constituinte (ANC) Florestan, um socialista participante na elaboração de uma Carta Magna “burguesa” em um processo majoritariamente dominado por conservadores, se pronunciou vários discursos em plenário. ${ }^{175}$

Florestan considerava a Constituinte como uma oportunidade de se redigir um novo texto constitucional que viabilizasse a implantação de reformas que permitissem a inclusão dos "de baixo" e instaurasse finalmente a ordem social competitiva no Brasil. Esse fator era considerado por ele como necessário à inclusão da maioria pobre na condição de cidadão, o que permitiria a constituição de sua identidade de classe e sua organização, de modo a se ter condições, então, de instaurar o socialismo. ${ }^{176}$

Como defensor do Estado laico, Florestan condenou o ensino religioso no âmbito escolar, pois infringia os alicerces da República. Por outro lado, defendia a educação política visando a formação de uma consciência crítica estudantil. Inclusive, neste mesmo diapasão, tratando-se de laicidade, leciona Hermes Lima:

Estado leigo é aquele em que as crenças e as Igrejas não podem pôr a serviço de seus dogmas, pontos de vista e explicações o prestígio e a força da autoridade pública. A religião passa a ocupar no Estado-leigo nova posição: pertence ao foro íntimo. As relações entre o Estado e a religião modificam-se: o Estado não defende

\footnotetext{
${ }^{172}$ Idem, p. 54.

${ }^{173}$ FERNANDES, F. Depoimento. In: MEMÓRIA viva da educação brasileira. v. 1. Brasília, DF: INEP, 1991, p. 21.

${ }^{174}$ SILVA, L. A.; LIMA, R. Florestan Fernandes na comissão de educação da constituinte: a luta pela escola pública, laica e gratuita no Brasil. Disponível em: <www.pucpr.br/eventos/educere/educere2009/anais/pdf/3122_1859.pdf>. Acesso em: 2 set. 2013, p. 7428 .

${ }^{175}$ Op. Cit., p. 44.

${ }^{176}$ Idem, p. 44.
} 
mais certo e determinado credo, mas a todos os credos assegura condições de vida e desenvolvimento. ${ }^{177}$

Lima ainda expõe as "reivindicações mínimas" da Igreja na Constituinte, realçando a oposição católica à "emenda que mandava que o plano geral de educação seria executado por sistemas leigos e gratuitos". ${ }^{178}$ Demasiadamente crítico em relação à Assembleia Nacional Constituinte, Florestan enfatizou em seu discurso publicado em 10 de julho de 1987 que

A hegemonia das elites das classes dominantes colocou os partidos em segundo plano (seria melhor dizer claramente: em partidos instrumentais para a dominação ideológica e política da burguesia, stricto sensu) e reduziu o clamor dos partidos de oposição à ordem em miados de gatos pardos em noites sem luar. (...) A Carta Constitucional fixou-se em um patamar de capitalismo selvagem, atribuindo prioridade quase exclusiva ao que é essencial para o capital nacional e, principalmente, para as multinacionais e a rede internacional de poder financeiro e político, que esmagam as potencialidades de desenvolvimento relativamente independente e equilibrado do País. Quanto ao que é vital para os trabalhadores, em sua expansão como e enquanto classe social e em seu potencial organizado de luta política, tudo foi mantido na soma zero. (...) Sequer avançou no sentido mais geral do reconhecimento da legitimidade da desobediência civil e de formas legais de insurgência proletária. ${ }^{179}$

Como defensor intransigente de um sistema de ensino exclusivamente público com vistas à integração e a solidariedade entre os diversos segmentos sociais, Florestan acreditava que através da escola pública e gratuita, seria viável a promoção da igualdade de oportunidades entre pobres e ricos. Isto se tornaria possível uma vez que a educação seria a base do sistema democrático. ${ }^{180}$

Sua concepção de igualdade preconizava que apenas por meio da educação comum se alcançaria a criação de uma comunidade de valores entre elite e as classes populares. Portanto, o principal desafio seria instituir um sistema de ensino comum com pobres e ricos na mesma situação. ${ }^{181}$ Uma das principais bandeiras de Florestan na ANC foi a defesa do financiamento público exclusivo para as escolas públicas, pois no contexto capitalista, os empresários têm que assumir os custos e riscos de seus empreendimentos. Ademais, por que destinar verbas a escolas particulares se o Estado alega escassez de verbas ao negar financiamento a políticas sociais? Logo, só com o financiamento exclusivo aos

\footnotetext{
${ }^{177}$ LIMA, H. Problemas de nosso tempo. São Paulo: Companhia Editora Nacional, 1935, p. 46.

${ }^{178}$ Idem, p. 62-63.

${ }^{179}$ NEVES, M. A. Florestan Fernandes: sociologia e política pela autonomia da nação. Instituto de Pesquisas Universitárias do Rio de Janeiro: Rio de Janeiro, 2009, p. 44.

${ }^{180}$ Idem, p. 53.

${ }^{181}$ Idem, p. 71.
} 
estabelecimentos oficiais, o poder público poderá fazer frente aos imensos desafios do sistema educacional pátrio.

Vale lembrar que a consagração do direito à educação está prevista em vários tratados, cartas de princípios e acordos internacionais que estabelecem a pauta de direitos consagradores da dignidade da pessoa humana.

Dentre eles destacam-se: a Declaração Universal dos Direitos do Homem, a Declaração Americana dos Direitos e Deveres do Homem, a Declaração dos Direitos da Criança, a Convenção Relativa à Luta Contra a Discriminação no Campo do Ensino, o Pacto Internacional de Direitos Econômicos, Sociais e Culturais, o Protocolo Adicional ao Pacto de San José da Costa Rica (Convenção Americana sobre Direitos Humanos em Matéria de Direitos Econômicos, Sociais e Culturais), denominado Protocolo de San Salvador e a Convenção sobre os Direitos da Criança.

O texto da Carta de 1988 é o mais amplo em matéria educacional, sendo disciplinada em dez artigos exclusivos (arts. 205 a 214) e surgindo em quatro outros dispositivos (arts. 22, XXIV, 23, V, 30, VI, e arts. 60 e 61 do Ato das Disposições Constitucionais Transitórias - ADCT).

A educação, qualificada como direito fundamental de todo cidadão, foi reconhecida como um direito público subjetivo com o advento da Constituição Federal de 1988 e ratificado no Estatuto da Criança e do Adolescente e na Lei de Diretrizes e Bases da Educação. Inclusive, quanto à natureza constitucional da educação como direito fundamental, cumpre salientar o que estabelece a Carta da República Federativa do Brasil no seu artigo 205:

Art. 205. A educação, direito de todos e dever do Estado e da família, será promovida e incentivada com a colaboração da sociedade, visando ao pleno desenvolvimento da pessoa, seu preparo para o exercício da cidadania e sua qualificação para o trabalho. ${ }^{182}$

De acordo com José Afonso da Silva ${ }^{183}$, o Estado deve aparelhar-se para fornecer, a todos, os serviços educacionais segundo os princípios e normas

\footnotetext{
${ }^{182}$ BRASIL, Constituição (1988). Constituição da República Federativa do Brasil, promulgada em 05 de outubro de 1988. Disponível em: <http://www.planalto.gov.br/ccivil_03/constituicao/constituicao.htm >. Acesso em: 2 dez. 2013..

${ }^{183}$ SILVA, J. A. Aplicabilidade das normas constitucionais. 6. ed. São Paulo: Malheiros, 2002, p. 312.
} 
constitucionais pertinentes, que devem ser interpretados visando sua plena e efetiva realização. A constituição considera o acesso ao ensino como direito publico subjetivo plenamente eficaz, de aplicabilidade imediata e exigível judicialmente, caso não seja prestado espontaneamente. Ele vai ainda mais além ao afirmar que ${ }^{184}$ :

O art. 205 contém uma declaração fundamental que, combinada com o art. $6^{\circ}$, eleva a educação ao nível dos direitos fundamentais do homem. Aí se afirma que a educação é direito de todos, com o que esse direito é informado pelo princípio da universalidade. Realça-lhe o valor jurídico, por um lado, a cláusula - a educação é dever do Estado e da família - constante do mesmo artigo, que completa a situação jurídica subjetiva, ao explicitar o titular do dever, da obrigação, contraposto àquele direito. Vale dizer: todos têm direito à educação e o estado tem o dever de prestála, assim como a família.

Assim, a educação não pode ser oferecida de modo a comprometer, com apoio em juízo de simples conveniência ou de mera oportunidade, a eficácia desse direito básico de índole social. Nesse sentido, Silva preconiza que ${ }^{185}$ :

As normas têm, ainda, o significado jurídico de elevar a educação à categoria de serviço público essencial que ao Poder Público impende possibilitar a todos. Daí a preferência constitucional pelo ensino público, pelo que a iniciativa privada, nesse campo, embora livre, é, no entanto, meramente secundária e condicionada (art. 209 e 213).

De acordo com José Cretella Júnior ${ }^{186}$, “cabe, em primeiro lugar, ao Estado, aos poderes públicos, proporcionar a educação a todos, promovendo e incentivando o ensino em todos os graus, mas não se dispensa, de modo algum, supletivamente a colaboração da sociedade". Ele enfatiza que "o legislador constituinte fixa - e com razão - três alvos que a educação deverá atingir: (a) a pessoa humana, (b) seu preparo para o exercício da cidadania e (c) sua qualificação para o trabalho", 187

O direito à educação é uma prerrogativa jurídica que, consequentemente, impõe, ao Estado, por efeito da alta significação social de que ela se reveste, a obrigação constitucional de criar condições objetivas que possibilitem, de maneira concreta, o efetivo acesso e atendimento no sistema educacional. Caso contrário, este incorre na pena de configurar-se inaceitável omissão governamental, apta a

\footnotetext{
${ }^{184}$ SILVA, J. A. Aplicabilidade das normas constitucionais. 6. ed. São Paulo: Malheiros, 2002, p. 312.

${ }^{185}$ Idem, p. 313.

${ }^{186}$ CRETELLA JÚNIOR, J. Comentários à constituição brasileira de 1988. 2. ed. Rio de Janeiro: Forense Universitária, 1993, p. 4405.

${ }^{187}$ Idem, p. 4405.
} 
frustrar, injustamente, por inércia, o integral adimplemento, pelo Poder Público, de prestação estatal que lhe impôs o próprio texto constitucional.

Representando uma prerrogativa constitucional indisponível, só a educação assegura além do pleno exercício da cidadania, a dignidade de pessoa humana, elementos essenciais do estado democrático de direito. Ademais, como atributo e essência da cidadania, ela tem por finalidade o desenvolvimento integral da personalidade humana e a sua consequente inclusão na sociedade.

Assim, o Poder Público não pode eximir-se do mandato constitucional, juridicamente vinculante, que lhe foi outorgado pela Carta Magna visando a efetividade desse direito básico de índole social. A supressão desse direito implica na impossibilidade do exercício pleno da cidadania, indispensável para o acesso aos demais direitos sociais, econômicos e culturais.

Conclui-se que o tratamento constitucional do direito à educação está intensamente associado à busca do ideal de igualdade que caracteriza os direitos de segunda dimensão. Os direitos sociais abarcam um sentido de igualdade material que se realiza por meio da atuação estatal dirigida à garantia de padrões mínimos de acesso a bens econômicos, sociais e culturais a quem não conseguiu a eles ter acesso por meios próprios. Em última análise, representam o oferecimento de condições básicas para que o indivíduo possa efetivamente se utilizar das liberdades que o sistema lhe outorga.

Politicamente, o bloco majoritário e, evidentemente, mais poderoso no cenário da Assembleia Nacional Constituinte era o Centro Democrático, também denominado "Centrão", que representava a base de apoio do governo do presidente José Sarney e que era composta principalmente por parlamentares do PMDB, PFL, PDS, PTB e outras legendas menores.

Contudo, ressalte-se que o ex-deputado Hermes Zanetti que, durante a Assembleia Nacional Constituinte de 1987-1988, presidiu a Subcomissão de Educação, Cultura e Esportes e integrou um grupo de constituintes comprometidos com a garantia da democratização da educação e da responsabilidade pública para com o ensino, afirmou em entrevista que "o 
processo do Brasil prova que a liberdade pode construir mais igualdade. E a esse processo está ligada a educação”. ${ }^{188}$

Ademais, o ex-deputado Hermes Zanetti (PMDB-RS) foi ainda mais além, pois declarou na mesma entrevista que

A grande disputa era entre a escola particular e a escola pública, esse pode ser considerado um divisor de águas. Outra grande disputa foi a fixação de um percentual mínimo da receita de impostos a ser destinado à educação. Conseguimos manter a vinculação de recursos para a educação, pois contamos com uma contribuição importante do Senador João Calmon e de algumas lideranças. Mas, por exemplo, José Serra, que é um economista muito respeitado, hoje governador de São Paulo, tive com ele “engalfinhamentos” poderosos nas outras etapas da Constituinte, porque ele era totalmente contra qualquer vinculação. ${ }^{189}$

Contudo, apesar de reconhecer a existência de perspectivas ou concepções ideológicas de educação que ocasionaram uma correlação de forças antagônicas tanto no âmbito da Subcomissão quanto na Constituinte em geral, ele destaca a relevância do grupo progressista minoritário que integrava.

Claro que havia uma visão ideológica de educação. A direita defendia a escola particular e queria todas as benesses para a escola particular; a esquerda, em especial um grupo - que tinha, entre outros, Florestan Fernandes, Jorge Hage, Octávio Elísio e eu - se empenhou, permanentemente, em defesa da escola pública. Muitas propostas foram discutidas, exatamente no sentido de defesa da escola pública. Uma das grandes discussões que se fez foi a distinção entre igualdade de oportunidades e igualdade de condições. A direita defendia igualdade de oportunidades e eu pude liderar um movimento que argumentava que não havia como garantir igualdade de oportunidades sem oferecer igualdade de condições, eu até dava exemplos objetivos da época, mostrando uma questão de fundo: a igualdade de oportunidades só poderia existir com igualdade de condições e, daí, pode-se imaginar o que era discutir com os conservadores, com a direita, a igualdade de condições, porque aí se apresentava toda uma perspectiva ideológica. $^{190}$

Os setores mais conservadores do Congresso, representados pelo Centro Democrático (PMDB, PFL, PTB, PDS e partidos menores), também denominado “Centrão” (composto principalmente por constituintes do PDS, PFL e PP). No âmbito da Subcomissão da Educação, Cultura e Esportes

[...] o deputado José Maria Eymael (PDC- SP) defendia a liberdade de ensino como sendo a liberdade de cada família de educar seus filhos de acordo com seus princípios filosóficos, morais e religiosos; para efetivar essa liberdade de escolha, dizia, muitos eram os caminhos, inclusive convênios e bolsas de estudos; no fundo,

\footnotetext{
${ }^{188}$ FARENZENA, N. Assembleia Nacional Constituinte de 1987-1988, educação e cidadania: entrevista com Hermes Zanetti. RBPAE - v.24, n.2, mai./ago. 2008, p. 352.

${ }^{189}$ Idem, p. 353.

${ }^{190}$ Idem, p. 354.
} 
o deputado fez a defesa da distribuição de verbas e recursos públicos para a escola privada. ${ }^{191}$

Além disso, não faltavam parlamentares que se opunham ao pensamento progressista do grupo de constituintes composto por Florestan Fernandes, Jorge Hage (PMDB-BA), Octávio Elísio (PMDB-MG) e Hermes Zanetti (PMDB-RS). Inclusive, o deputado Gerson Peres (PDS - PA) solidário com a "livre iniciativa na área do ensino; defendia a escola particular como algo inerente às tradições históricas e culturais do Brasil, devendo ser garantida pelos princípios constitucionais. $^{192}$

Nestes mesmo diapasão, o constituinte capixaba Nelson Aguiar (PMDBES), ao arrepio das propostas defendidas pelos seus colegas de partido supramencionados discordou com a posição de Olívio Dutra (PT-RS) que defendia a aplicação preferencial de recursos públicos na escola pública. Ele chegou a declarar em plena sessão o seguinte: "não vejo porque o Estado não subsidiar, então, a escola particular, com recurso que o particular também colocou no cofre público, e aí o ensino seria público”. ${ }^{193}$

Por outro lado, vale assinalar a posição do relator desta Subcomissão, Artur da Távola (PMDB-RJ) marcadamente favorável à destinação de recursos públicos exclusivamente para instituições escolares públicas.

[...] eu lhes deixo esse apelo do fundo da minha convicção - e, ao mesmo tempo, garantir ao ensino básico, fundamental, obrigatório, a plenitude das verbas públicas. Não construiremos jamais, neste País, uma educação democrática, se não garantirmos a exclusividade das verbas públicas para a escola pública e se não libertarmos o ensino privado das peias do Estado. ${ }^{194}$

Cumpre ressaltar ainda que tratando de outro ponto de conflito, o constituinte Olívio Dutra no seio desta Subcomissão da ANC, também defendeu a laicidade da educação ao afirmar que "o ensino religioso na escola púbica atenta contra o Estado, que deve ser um Estado laico”. 195

Deste modo, evidenciam-se, mais uma vez, os específicos pontos de conflito ou de tensão em torno da temática da educação que geraram embates ou

\footnotetext{
${ }^{191}$ LIMA, L. P. M. A atuação da esquerda no processo constituinte: (1986-1988). Brasília: Câmara dos Deputados, 2009, p. 241.

${ }^{192}$ LIMA, L. P. M. A atuação da esquerda no processo constituinte: (1986-1988). Brasília: Câmara dos Deputados, 2009, p. 241.

${ }^{193}$ BRASIL. Atas da Assembleia Nacional Constituinte de $\mathbf{1}^{\mathbf{0}}$ de abril de 1987, p. 80.

${ }^{194}$ Idem, p. 164.

${ }^{195}$ Idem, p. 81.
} 
enfrentamentos entre diversos parlamentares constituintes que, por sua vez, defenderam suas concepções ou perspectivas ideológicas de educação básica.

\section{3}

\section{A Dinâmica do Contexto Parlamentar Gerador da Lei de Diretrizes e Bases da Educação Nacional (LDB)}

A análise do papel desempenhado pelo Congresso Nacional na discussão e formulação da legislação educacional é imprescindível para a compreensão dos rumos da política educacional do país. Isto se justifica pela possibilidade de constatação da associação entre as proposições educacionais apresentadas, discutidas e aprovadas e o âmbito de suas respectivas tendências ou orientações sociopolíticas mais amplas e gerais.

Portanto, nesta parte da dissertação objetiva-se investigar o comportamento do Congresso Nacional durante o longo processo de tramitação da Lei de Diretrizes e Bases da Educação que está em vigor atualmente. Deste modo, pretende-se captar e distinguir os matizes ou vieses sociopolíticos peculiares dos diversos grupos de interesse e pressão que protagonizaram os debates que culminaram na elaboração e promulgação da Lei nº 9.394/96.

Assim, uma vez que o inciso XXIV do artigo 22 da Constituição da República Federativa do Brasil de 1988 estabelece que "compete privativamente à União legislar sobre diretrizes e bases da educação nacional", coube ao Congresso Nacional a tarefa de refletir sobre a situação da educação no país, discutir propostas antagônicas de enfrentamento dos problemas e desafios educacionais e, por fim, elaborar o novo texto legal.

Inclusive, neste ponto, vale ainda ressaltar a observação de Nelson Joaquim quando destaca que, diferentemente de suas antecessoras encaminhadas pelo Poder Executivo, "pode-se identificar na nova LDB um traço bastante singular: ela foi a única que nasceu no seio do Poder Legislativo”, processo que teria sido alterado nos lances finais de sua tramitação. ${ }^{196}$

Consequentemente, como fruto de todo o longo processo legiferante mencionado, promulgou-se a Lei $\mathrm{n}^{0} 9.394$ em 20 de dezembro de 1996, que

\footnotetext{
${ }^{196}$ JOAQUIM, N. Direito educacional brasileiro: história, teoria e prática. 1. ed. Rio de Janeiro: Livre Expressão, 2009, p. 92.
} 
estabelece as diretrizes e bases da educação nacional. O teor dessa norma possui reconhecida relevância em virtude de sua abrangência e instrumentalidade no que tange à promoção do direito fundamental à educação já consagrado pelo texto constitucional promulgado em 1988. Inclusive, acredita-se que o advento da atual Lei de Diretrizes e Bases da Educação Nacional tenha implicado na tomada de novos rumos para as políticas públicas educacionais brasileiras.

Entretanto, à guisa de introdução ao exame das intensas disputas e tensões evidenciadas ao longo do processo de discussão sobre a temática da educação e deliberação da atual LDB, é oportuno apresentar uma apreciação dos seus antecedentes históricos, que revelam a tônica da abordagem do tópico "Diretrizes e Bases da Educação Nacional” ao longo do tempo.

Conforme já exposto, as Constituições de 1824 e de 1891 pouco abordavam a assunto educação. Inclusive, pressupondo a autonomia das unidades federativas, a Carta Magna de 1891 preconizava que à Federação cabia exclusivamente o ensino superior da capital (art. 34), a instrução militar (art. 87) e a missão de "animar, no país, o desenvolvimento das letras, artes e ciências" (art. 35).

Assim, até então, a discussão e a elaboração das diretrizes e bases da educação haviam sido deixadas a cargo dos respectivos estados-membros da Federação. Inclusive, cumpre ressaltar que, somente em 1931 criou-se o denominado Ministério da Educação e Saúde Pública. Pois, até então, as matérias pertinentes à educação eram disciplinadas pelo Departamento Nacional do Ensino, órgão vinculado ao Ministério da Justiça.

Por outro lado, pela primeira vez na história do constitucionalismo pátrio, a Constituição da República dos Estados Unidos do Brasil, promulgada em 16 de julho de 1934, assim estabelecia no inciso XIV do seu artigo $5^{\circ}$ e na alínea "a” do artigo 150, respectivamente: "Compete privativamente à União traçar as diretrizes da educação nacional" e "Compete à União fixar o plano nacional de educação, compreensivo do ensino de todos os graus e ramos, comuns e especializados; e coordenar e fiscalizar a sua execução, em todo o território do País". Além disso, o artigo 152 da mesma Carta Magna ainda previa o órgão encarregado de preparar o mencionado plano:

Art. 152 - Compete precipuamente ao Conselho Nacional de Educação, organizado na forma da lei, elaborar o plano nacional de educação para ser aprovado pelo 
Poder Legislativo e sugerir ao Governo as medidas que julgar necessárias para a melhor solução dos problemas educativos bem como a distribuição adequada dos fundos especiais. ${ }^{197}$

Contudo, somente em 20 de dezembro de 1961, depois de treze anos de debate parlamentar e tramitação, o presidente João Goulart promulgava a primeira LDB, ou seja, vinte e sete anos após sua primeira previsão pela Carta Magna de 1934. Na verdade, a discussão e formulação do texto da Lei $n^{0} 4.024 / 61$ decorreu da disposição do artigo 5, inciso XV, alínea “d” da Constituição dos Estados Unidos do Brasil, promulgada em 18 de setembro de 1946, que previa: "Compete à União legislar sobre diretrizes e bases da educação nacional".

No que se refere ao posicionamento político-partidário ao longo do processo de formulação da primeira LDB, é interessante observar que a função desempenhada pelo Congresso Nacional "foi de deformação, desfigurando o projeto original”198, cuja vocação descentralizadora era apoiada pela Associação Brasileira de Educação.

Inclusive, relatam-se episódios de intensa e veemente pressão por parte de representantes da iniciativa privada e religiosa, que estavam determinados a impor hegemonicamente seus interesses e conveniências no teor da Lei de Diretrizes e Bases da Educação Nacional. Esse quadro conflituoso já revela a tendência histórica que o debate referente à formulação da legislação destinada à orientação da política pública educacional pátria tem de sair da esfera político-partidária propriamente dita e terminar na arena da mera luta ideológica ${ }^{199}$.

Todavia, em virtude do predomínio do método de harmonização dos interesses opostos de ambos os lados, o texto legal resultante não representava a plenitude das expectativas de nenhum dos polos ideológicos antagônicos. Em outras palavras, como fruto de concessões recíprocas em um contexto político marcado pela estratégia da conciliação, o texto aprovado consistiu em uma “solução de compromisso” entre as correntes interessadas no tema. Inclusive, os efeitos de tal estratégia conciliadora podem ser nitidamente percebidos ao

\footnotetext{
${ }^{197}$ BRASIL. Constituição (1934). Constituição da República dos Estados Unidos do Brasil, promulgada em 16 de julho de 1934 . Disponível em: <http://www.planalto.gov.br/ccivil_03/constituicao/constituicao34.htm>. Acesso em: 2 dez. 2013. ${ }^{198}$ SAVIANI, D. Política e educação no Brasil; o papel do Congresso Nacional na legislação do ensino. 4. ed. Campinas: Autores Associados, 1999, p. 144.

${ }^{199}$ SAVIANI, D. A nova lei da educação: trajetória, limites e perspectivas. 11. ed. Campinas: Autores Associados, 2008, p. 15-16.
} 
confrontarem-se os principais títulos do projeto original de 1948, o substitutivo Lacerda de 1958 e o texto finalmente promulgado como a Lei $n^{\circ} 4.024 / 61 .{ }^{200}$

Deste modo, a primeira LDB consagrou o direito à educação com base em princípios liberais e democráticos nitidamente oriundos do ideário da Revolução Francesa, conforme manifesto no teor do Título I "Dos Fins da Educação" e do Título II "Do Direito à Educação" respectivamente transcritos abaixo.

Art. $1^{\circ}$ A educação nacional, inspirada nos princípios de liberdade e nos ideais de solidariedade humana, tem por fim: a) a compreensão dos direitos e deveres da pessoa humana, do cidadão, do Estado, da família e dos demais grupos que compõem a comunidade; b) o respeito à dignidade e às liberdades fundamentais do homem; c) o fortalecimento da unidade nacional e da solidariedade internacional; d) o desenvolvimento integral da personalidade humana e a sua participação na obra do bem comum; e) o preparo do indivíduo e da sociedade para o domínio dos recursos científicos e tecnológicos que lhes permitam utilizar as possibilidades e vencer as dificuldades do meio; f) a preservação e expansão do patrimônio cultural; g) a condenação a qualquer tratamento desigual por motivo de conviçcão filosófica, política ou religiosa, bem como a quaisquer preconceitos de classe ou de raça.

Art. $2^{\circ}$ A educação é direito de todos e será dada no lar e na escola. Parágrafo único. À família cabe escolher o gênero de educação que deve dar a seus filhos.

Art. $3^{\circ} \mathrm{O}$ direito à educação é assegurado: I - pela obrigação do poder público e pela liberdade de iniciativa particular de ministrarem o ensino em todos os graus, na forma de lei em vigor; II - pela obrigação do Estado de fornecer recursos indispensáveis para que a família e, na falta desta, os demais membros da sociedade se desobriguem dos encargos da educação, quando provada a insuficiência de meios, de modo que sejam asseguradas iguais oportunidades a todos. ${ }^{201}$

Em seguida, iniciou-se uma segunda fase na formulação das políticas públicas educacionais, que ficou marcada pela elaboração de leis de reformas na organização do ensino. A Lei $n^{0} 5.540$ entrou em vigor em 28 de novembro de 1968 com a missão de fixar normas de organização e funcionamento do ensino superior e sua articulação com a escola média. Por sua vez, a Lei $n^{0}$ 5.692, publicada em 11 de agosto de 1971, destinava-se a fixar diretrizes e bases para o ensino de $1^{\circ}$ e $2^{\circ}$ graus.

O governo militar, que assumiu o poder em função do golpe de 1964, considerou que não seria necessária uma revogação total da LDB nº 4.024/61, já que se pretendia assegurar a continuidade da ordem socioeconômica vigente. Portanto, as diretrizes gerais da política pública educacional em vigência não

\footnotetext{
${ }^{200}$ Idem, p. 18-20.

${ }^{201}$ BRASIL. Lei $\mathbf{n}^{\mathbf{0}}$ 4.024, de 20 de dezembro de 1961. Fixa as diretrizes e bases da educação nacional. Disponível em: < http://www.planalto.gov.br/ccivil_03/leis/14024.htm >. Acesso em: 2 dez. 2013.
} 
necessitavam ser modificadas, mas apenas ajustadas de forma a estarem em sintonia com o novo contexto político. Então, tal ajuste se deu por meio da supramencionada lei da reforma universitária (Lei ${ }^{0} 5.540 / 68$ ) e da supracitada lei de reforma do ensino primário e médio, que passou a ser denominado ensino de primeiro e segundo graus (Lei $\left.\mathrm{n}^{0} 5.692 / 71\right) .{ }^{202}$

É valido destacar ainda que a lei da reforma universitária (Lei $n^{0} 5.540 / 68$ ) surgiu a partir de um projeto resultante de estudos desenvolvidos por um Grupo de Trabalho criado com essa finalidade, por decreto do então presidente da república, marechal Arthur da Costa e Silva. Por sua vez, a lei de reforma do ensino primário e médio (Lei $n^{0} 5.692 / 71$ ) teve origem no projeto decorrente das análises efetuadas por outro Grupo de Trabalho convocado pelo então presidente da República, general Emílio Garrastazu Médici.

À luz dessa apreciação retrospectiva do papel histórico do Congresso Nacional na formulação da legislação educacional pátria, empreende-se um exame do cenário político que caracterizou os oito longos anos de tramitação da nova Lei de Diretrizes e Bases da Educação Nacional no parlamento federal brasileiro. Assim, pretende-se analisar o significado político e jurídico do papel desempenhado pelo Congresso Nacional na elaboração da atual LDB.

Além disso, assim como ocorreu na tramitação da seção sobre educação na Constituição federal de 1988, houve mobilização de educadores com vistas ao acompanhamento e influência direta junto aos parlamentares no processo de elaboração da nova lei. Nesta fase, o objetivo era evitar que a discussão de relevantes questões ficasse fora da lei especial de educação. ${ }^{203}$

Considerando os debates e embates que marcaram a dilatada trajetória da atual LDB no Congresso Nacional, constata-se que o parlamento federal tornou-se a arena de disputas e deliberações que finalmente culminaram na produção da nova lei promulgada em dezembro de 1996.

Apenas dois meses após a promulgação da Constituição Federal em 05 de outubro de 1988, face à nova realidade constitucional, o deputado Octávio Elísio

\footnotetext{
${ }^{202}$ SAVIANI, D. A nova lei da educação: trajetória, limites e perspectivas. 11. ed. Campinas: Autores Associados, 2008, p. 20.

${ }^{203}$ Idem, p. 36.
} 
(PSDB - MG) apresentou à Câmara dos Deputados o projeto de lei número 1.258-

A/88 com vistas à elaboração da lei de diretrizes e bases da educação nacional.

Destacam-se no teor desse projeto original uma concepção de educação inspirada nos ideais democráticos de igualdade e de liberdade, solidariedade humana e cidadania. Além disso, garantia-se o direito à educação, a previsão do sistema nacional de educação e a regulamentação da administração e dos recursos para a educação a defesa da escola pública segundo um modelo democrático. Inclusive, vale destacar as palavras do próprio deputado Octávio Elísio:

O processo constituinte encerrou-se em outubro de 1988. Em dezembro, apresentei o primeiro projeto de lei de diretrizes e bases da educação, fruto da discussão que se vinha fazendo pela comunidade educacional. O meu projeto nada mais era do que uma contribuição sintetizada por Demerval Saviani, a partir da IV Conferência Brasileira de Educação, cujas conclusões, registradas na Carta de Goiânia, de 1986, apresentavam algumas propostas em termos de LDB. O meu projeto era constituído essencialmente dessa proposta vinda da Conferência, da ANPED, incorporando ainda sugestões de Jacques Veloso, principalmente no que diz respeito à questão do financiamento da educação. ${ }^{204}$

Após ter sofrido três emendas por parte do próprio parlamentar autor (Octávio Elísio) em 15 de dezembro de 1988, 04 de abril de 1989 e 13 de junho de 1989, o texto foi submetido ao exame da Comissão de Constituição, Justiça e Redação, na qual obteve parecer favorável à constitucionalidade, juridicidade e boa técnica legislativa e foi aprovado em 29 de junho de $1989 .^{205}$

Em março de 1989 o deputado Ubiratan Aguiar (PMDB-CE), então presidente da Comissão de Educação, Cultura e Desporto da Câmara, instituiu um Grupo de Trabalho da Lei de Diretrizes e Bases da Educação Nacional sob a coordenação do deputado Florestan Fernandes (PT-SP) e relatoria do deputado Jorge Hage (PSDB-BA).

Além de emendas e projetos anexados ao projeto original do deputado Octávio Elísio, o relator considerou ainda as inúmeras sugestões propostas por diversas instituições ouvidas em audiências públicas, debates e seminários temáticos para discussão da reforma educacional. Inclusive, o relator avaliou "o

\footnotetext{
${ }^{204}$ AGUIAR, U. D; MARTINS, R. C. R. LDB: memória e comentários. Fortaleza: Universidade Federal do Ceará, 1998, p. 14-15.

${ }^{205}$ SAVIANI, D. A nova lei da educação: trajetória, limites e perspectivas. 11. ed. Campinas: Autores Associados, 2008, p. 57.
} 
que talvez tenha sido o mais democrático e aberto método de elaboração de uma lei de que se tem notícia no Congresso Nacional”206.

Vale ressaltar que a iniciativa desse projeto teve origem na esfera do Poder Legislativo e se desenvolveu por meio de uma gestação no seio da comunidade educacional em contraposição à tradição histórica já demonstrada anteriormente de reformas educacionais decorrentes de projetos de iniciativa e interesse exclusivos do Poder Executivo. Mais uma vez, vale à pena realçar as palavras do próprio autor do projeto original, que se considera apenas um dos participantes da discussão e teria deixado de ser o responsável pelo projeto da LDB:

Os diversos segmentos da sociedade, sejam ligados à educação pública ou privada, confessional ou não, as igrejas, todos participaram, todos foram ouvidos. Duvido que algum segmento comprometido com a educação não tenha sido convocado a participar e não tenha trazido a sua sugestão. Caracterizou-se, enfim, um processo único, fruto de uma mobilização anterior e da credibilidade de que realmente ele pudesse acontecer no Legislativo. ${ }^{207}$

Enfim, entre 9 de maio e 28 de junho de 1990 iniciou-se o processo de negociação e votação na Comissão de Educação, Cultura e Desporto da Câmara dos Deputados, então presidida pelo Deputado Carlos Sant'Anna. Lá empreendeuse a apreciação detalhada do texto, além de transações constantes que possibilitaram ao relator reestruturar o texto gerando a terceira versão de seu substitutivo. Ao final, o texto foi aprovado unanimemente como o substitutivo da Comissão. Seu teor estava disposto em 172 artigos fracionados em muitos parágrafos, incisos e alíneas e distribuídos em 20 capítulos. $^{208}$

Indiscutivelmente, em comparação com a conjuntura em vigor na época, o texto consistia em progresso, pois sua tônica geral era progressista, apesar da presença de diversos tópicos que precisariam ser reexaminados e alterados.

Ao longo da tramitação dos anteprojetos da Lei de Diretrizes e Bases da Educação Nacional percebe-se um antagonismo entre duas perspectivas de sociedade e de educação defendidos por sujeitos oriundos de dois domínios distintos: o espaço dos educadores e o círculo oficial. Por outro lado, o Fórum Nacional em Defesa da Educação Pública na LDB, legítimo representante das

\footnotetext{
${ }^{206}$ Idem, p. 57.

${ }^{207}$ AGUIAR, U. D; MARTINS; R. C. R. LDB: memória e comentários. Fortaleza: Universidade Federal do Ceará, 1998, p. 15.

${ }^{208}$ Idem, p. 58.
} 
entidades da sociedade civil, tendo acompanhado as tensões legislativas no Congresso Nacional e participado das discussões e embates entre esses dois mundos opostos, também alcançou sucesso em alguns dispositivos legais.

Consequentemente, as políticas públicas educacionais pátrias que se concretizaram na LDB/1996 não foram determinadas unicamente pelo Poder Executivo via Ministério da Educação, que se consagrou vencedor por uma 'manobra regimental' nos momentos de votação do Substitutivo de LDB apresentado pelo senador Darcy Ribeiro no âmbito do Poder Legislativo, no Senado da República. ${ }^{209}$

Mesmo já aprovado pela Comissão de Educação, o substitutivo Jorge Hage ainda passaria por uma extensa tramitação na Câmara dos Deputados: Comissão de Finanças no segundo semestre de 1990; Plenário no primeiro semestre de 1991; retorno às comissões onde permaneceu até sua aprovação final na sessão plenária da Câmara de 13 de maio de 93.

Ao passo que o projeto de LDB tramitava na Câmara dos Deputados, iniciativas análogas surgiram no Senado Federal, como o projeto $n^{0}$ 208/1989 do Senador Jorge Bornhauser (PFL-SC) tratando do ensino superior e que foi aprovado pela Comissão de Educação em maio de 1990. Considerando-se que o tópico já era disciplinado pela LDB e em virtude da atuação do Fórum Nacional em Defesa da Escola Pública, cessou-se a sua tramitação.

Por outro lado, o Senador Marco Maciel (PFL-PE) desistiu de apresentar um projeto paralelo de LDB no Senado devido a um acordo com o deputado Jorge Hage, reforçado com o compromisso público de que nada se deliberaria sobre essa matéria na Comissão de Educação do Senado antes da apreciação do projeto oriundo da Câmara. ${ }^{210}$

O Fórum Nacional em Defesa da Educação Pública na LDB, composto por entidades da sociedade civil, oferecia as suas propostas aos parlamentares simpatizantes com a causa da educação pública, gratuita, laica e de qualidade para todos os brasileiros, em todos os níveis e modalidades de formação. Ainda que

\footnotetext{
${ }^{209}$ BRZEZINSKI, I. Tramitação e desdobramentos da LDB/1996: embates entre projetos antagônicos de sociedade e de educação. Trab. Educ. Saúde, Rio de Janeiro, v. 8 n. 2, p. 185-206, jul./out.2010, p. 186.

${ }^{210}$ SAVIANI, D. A nova lei da educação: trajetória, limites e perspectivas. 11. ed. Campinas: Autores Associados, 2008, p. 127.
} 
não atendido em suas reivindicações pelos parlamentares defensores do ensino privado, o Fórum se fazia presente nas audiências e debates.

Contudo, modificada a conjuntura política e a correlação de forças, em maio de 1992 protocolizou-se na Comissão de Educação do Senado o projeto de LDB do Senador Darcy Ribeiro (PDT-RJ), assinado pelos senadores Marco Maciel (PFL-PE) e Maurício Correa (PDT-DF) e relatoria do senador Fernando Henrique Cardoso (PSDB-SP). Os oposicionistas a esse projeto afirmavam que o Poder Executivo por meio dele desejava ficar livre para elaborar a política educacional de acordo com suas conveniências e sem influência da sociedade civil organizada. Para Saviani, enquanto projeto da Câmara tinha sido fruto da democracia participativa marcada pelo compartilhamento das decisões entre as autoridades governamentais e a comunidade educacional, o projeto de Darcy baseava-se uma concepção de democracia representativa. ${ }^{211}$

Darcy logrou apressar a aprovação de seu projeto por meio do "novo Regimento Interno do Senado que dava às decisões das comissões temáticas caráter terminal” e tornava-o automaticamente aprovado no Senado. Assim, seguiu para a apreciação da Câmara cujo projeto seria, então, preterido como matéria vencida. Entretanto, o senador João Calmon liderou um requerimento para que a matéria fosse apreciada em Plenário. Por sua vez, Darcy obteve um pedido de urgência para agilizar a tramitação de seu projeto no Plenário.

Entrementes, uma nova conjuntura político-partidária surgiu em virtude do impeachment do ex-presidente Collor. E sob a presidência de Itamar Franco, o Ministro da Educação, Murilo Hingel, diversamente dos ministros de Collor, revela-se favorável ao projeto de LDB da Câmara.

O requerimento de urgência de Darcy estava na pauta da reunião do dia 18 de fevereiro de 1993, mas ministro Murilo Hingel e o líder do governo no Senado, senador Pedro Simon (PMDB-RS), articularam impedir a sua aprovação. Além disso, aceita a questão de ordem levantada pelo senador Jarbas Passarinho (PDSPA) o projeto Darcy voltou à Comissão de Educação onde, todavia, não foi mais apreciado. $^{212}$

\footnotetext{
${ }^{211}$ SAVIANI, D. A nova lei da educação: trajetória, limites e perspectivas. 11. ed. Campinas: Autores Associados, 2008, p. 128-129.

${ }^{212}$ Idem, p. 129-130.
} 
No que tange ao substitutivo Jorge Hage, foi encaminhado à Comissão de Finanças e Tributação no segundo semestre de 1990, sob a relatoria de Sandra Cavalcanti (PFL-RJ), que apesar de afirmar seu compromisso com o projeto, relutava em emitir seu parecer. Ocorre que, em função de disposição regimental, os projetos não aprovados em todas as comissões ao final de uma legislatura são compulsoriamente arquivados. Se até o fim do segundo semestre de 1990 o projeto não fosse apreciado pela Comissão de Finanças e Tributação, poderia se perder todo o trabalho concretizado. Contudo, em 28 de novembro de 1990, o relatório foi apresentado. Porém, usurpando atribuição da Comissão de Educação, a relatora propôs a inclusão de 25 subemendas versando sobre matérias de mérito que refletiam interesses de escolas privadas, particularmente confessionais. ${ }^{213}$

Após sobreviver a manobras com "pedidos de vista", na reunião do dia 12 de dezembro de 1990, mediante esforço dos deputados Jorge Hage, Octávio Elísio, Hermes Zanetti e membros do Fórum em Defesa da Escola Pública na LDB para assegurar o quorum adequado à aprovação, o substitutivo com as 25 emendas da relatora foi aprovado por unanimidade.

Uma faceta bem mais conservadora do Congresso Nacional emergiu eleições de outubro de 1990 para a legislatura que iniciaria em fevereiro de 1991. Além disso, parlamentares que exerceram função crucial na tramitação do projeto tais como o relator Jorge Hage (PDT-BA), Octávio Elísio (PSDB-MG), Hermes Zanetti (PSDB-RS), Carlos Sant'Anna (PMDB-BA), Lídice da Mata (à época no PC do B-BA), Gumercindo Milhomem (PT-SP) já não eram mais congressistas.

Assim, ao passo que na fase anterior a ação dos partidos progressistas assegurou o domínio do processo de debate e deliberação da LDB, nesse novo período as relatorias das comissões de Educação e de Constituição e Justiça pertenciam ao PDS, partido de tendências conservadoras e propenso aos interesses privatistas da esfera educacional.

Na primeira comissão a relatoria ficou a cargo da deputada Ângela Amin (PDS-SC). Já segunda assumiu o deputado Edevaldo Alves da Silva (PDS-SP), proprietário de uma grande rede de instituições escolares em São Paulo. Ademais,

\footnotetext{
${ }^{213}$ SAVIANI, D. A nova lei da educação: trajetória, limites e perspectivas. 11. ed. Campinas: Autores Associados, 2008, p. 151.
} 
na Comissão de Finanças tornou-se relator Luís Carlos Hauly (PMDB-PR, depois PST-PR), membro do Bloco Economia de Mercado. ${ }^{214}$

Conforme já exposto, o projeto substitutivo de LDB já aprovado em várias Comissões (Constituição, Justiça e Redação, Educação, Cultura e Desporto e de Finanças e Tributação) encaminhado em janeiro de 1991 à Mesa da Câmara dos Deputados confrontou-se com numerosos obstáculos. No final de maio foi inserido na ordem do dia do Plenário da Câmara e, apreciado, recebeu 1.263 emendas, configurando motivo para seu retorno às Comissões Técnicas para apreciação dessas emendas. Embora o Colégio de Líderes tivesse instituído, em setembro de 1991, uma Comissão Suprapartidária para acelerar a apreciação do projeto, as negociações não se concluíram naquele ano.

Já que as negociações não prosseguiam, o Colégio de Líderes marcou entre 20 e 30 de maio de 1992 a votação na Comissão de Educação do parecer da relatora Ângela Amin sobre as 1.263 emendas. Iniciada a votação, registraram-se 1.622 destaques dos quais aproximadamente 80\% (1.287) oferecidos pelo deputado Eraldo Tinoco (PFL-BA), líder do governo Collor na Câmara dos Deputados. Então, a obstrução das negociações era uma estratégia do Bloco Parlamentar, constituído por deputados do PFL, PRN, PSC e PMN.

Inclusive, Eraldo Tinoco, além de representante do governo, era o intransigente líder desse Bloco. Uma vez que Tinoco se recusava a retirar os destaques, a solução articulada pelo Fórum em conjunto com os deputados Celso Bernardi e Ubiratan Aguiar, foi enviar o requerimento de urgência-urgentíssima ao Presidente da Câmara para aprovação em agosto. Porém, isso não foi possível devido à falta de quórum nas convocações efetuadas.

Todavia, a posse de Itamar Franco na presidência da República e Murilo Hingel no Ministério da Educação ensejaram uma conjuntura política mais propícia ao avanço do projeto. Obteve-se a aprovação do requerimento de urgência-urgentíssima e em novembro de 1992 começou no Plenário da Câmara dos Deputados a votação do projeto da LDB e das emendas.

Sob a relatoria do deputado Edevaldo Alves da Silva (PDS-SP), dono de uma influente rede de escolas, a Comissão de Justiça se tornou na trincheira dos

\footnotetext{
${ }^{214}$ Idem, p. 152.
} 
empresários da educação. Mediante uma manobra repetida com sucesso depois por Darcy Ribeiro no Senado, os representantes dos empresários da educação no Congresso incluíram o parecer do relator na pauta da Comissão de Justiça em setembro de 1991.

No que tange à relatoria da Comissão de Educação, o teor do seu relatório beneficiou os interesses privados como se pode notar principalmente nos capítulos alusivos ao Sistema Nacional de Educação, ao Financiamento, e à Carreira dos Profissionais da Educação. Sem aprovação pela Comissão, o parecer da relatora foi encaminhado à apreciação do Plenário da Câmara.

Aprovado na primeira sessão, por acordo, o Substitutivo Jorge Hage junto com os três pareceres, ressalvados os destaques. Na análise dos destaques iniciouse pelos 1.275 apresentados ao Parecer da Comissão de Educação. Nas reuniões de negociação, os pontos de consenso eram levados ao Plenário para votação, mas aqueles nos quais havia divergências eram "sobrestados" para votação posterior.

Apesar de já ter sido aprovado pela Comissão de Constituição, Justiça e Redação, Comissão de Educação, Cultura e Desporto assim como pela Comissão de Finanças e Tributação, uma vez apreciado pelo Plenário da Câmara dos Deputados após seu encaminhamento em janeiro de 1991, recebeu 1263 emendas que levaram ao reexame do projeto naquelas mesmas Comissões Técnicas.

Assim, atuando em novembro e dezembro de 1992, durante a convocação extraordinária em janeiro de 1993 e na nova legislatura a partir de 15 de fevereiro de 1993, a Câmara dos Deputados logrou a aprovação final do projeto-substitutivo da Lei de Diretrizes e Bases da Educação Nacional em 13 de maio de 1993. O texto aprovado era bastante próximo da versão resultante do Relatório de Ângela Amin. A alteração mais visível foi no Título V que deixou de ser "Do Sistema Nacional de Educação", passando para "Da Organização da Educação Nacional".

O projeto de Lei $n^{0}$ 1158-B/1988, aprovado na Câmara Federal, no Senado foi identificado como PLC n ${ }^{0}$ 101/1993 "que fixa diretrizes e bases da educação nacional", tendo sido designado relator na Comissão de educação o senador Cid Sabóia (PMDB-CE).

Havia a possibilidade de eliminação da exigência de se fixar as diretrizes e bases da educação nacional. Aliás, a deputada Sandra Cavalcanti (PFL-RJ), 
promotora intransigente da livre iniciativa na esfera educacional, achava que as diretrizes e bases deveriam se restringir ao que já estava previsto na Seção I - (Da Educação), do Capítulo III da Constituição Federal.

O relator senador Cid Sabóia seguiu um procedimento parecido daquele da fase de constituição do substitutivo Jorge Hage, motivando audiências públicas, consultando os que tinham contribuições a dar e ouvindo os representantes do governo, dos partidos e das entidades educacionais, além do Fórum em Defesa da Escola Pública. O resultado foi um novo substitutivo que mantinha a estrutura do projeto aprovado na Câmara, tendo absorvido aspectos abrigáveis do PLS $n^{0}$ 67/1992, de autoria de Darcy Ribeiro.

O Poder Executivo (MEC), resgatando a função de tratar das políticas educacionais, passou a dominar o processo em relação à LDB. Além disso, o próprio autor do anteprojeto do Senado, o senador Darcy Ribeiro, nessa fase de tramitação do projeto foi escolhido relator na Comissão de Constituição, Justiça e Cidadania (CCJC).

Investido de autoridade, ele apontou inúmeras inconstitucionalidades aos dispositivos do anteprojeto na Câmara e ao Substitutivo Cid Sabóia, declarando seu voto pela rejeição de ambos. Ademais, as estratégias regimentais beneficiaram a aprovação do Substitutivo Darcy Ribeiro pelo plenário do Senado. De imediato foi encaminhado à Câmara dos Deputados, como projeto único e depois sancionado pelo presidente da República em 20 de dezembro de $1996 .^{215}$

Finalmente, nas próprias palavras do relator do projeto substitutivo, o exdeputado Jorge Hage:

O resultado foi um Substitutivo efetivamente fiel ao que buscando tornar realidade, na prática, a universalização da educação básica, obrigatória e gratuita, como um direito de todos os brasileiros e um dever do Estado e da família, com a colaboração da sociedade; que visava à efetiva oportunidade de acesso para todos, e articulava a Educação com a ocupação, pondo ênfase na crucial relação entre Escola e Trabalho; que garantia a gratuidade efetiva e comprometia-se com a gestão democrática da educação; que fortalecia, acima de tudo, a Escola Pública e assegurava recursos capazes de oferecer remuneração digna e aperfeiçoamento constante ao corpo docente $[. . .]^{216}$

\footnotetext{
${ }^{215}$ BRZEZINSKI, I. Tramitação e desdobramentos da LDB/1996: embates entre projetos antagônicos de sociedade e de educação. Trab. Educ. Saúde, Rio de Janeiro, v. 8 n. 2, p. 185-206, jul./out.2010, p. 190.

${ }^{216}$ AGUIAR, U. D.; MARTINS, R. C. R. LDB: memória e comentários. Fortaleza: Universidade Federal do Ceará, 1998, p. 23.
} 
Por outro lado, é valido também ressaltar o depoimento do ex-deputado Ubiratan Aguiar: "Se no nível superior as novas normas legais e as discussões delas decorrentes estão bem adiantadas, [...] Praticamente não se conseguiu dobrar o tradicionalismo administrativo no sistema de educação básica."217

Diante do exposto, cumpre destacar os principais dispositivos da nova LDB referentes à promoção do direito fundamental à educação básica, que asseguram os ideais e princípios enfatizados ao longo deste trabalho, a saber: acesso à escola pública, obrigatória, com gestão democrática e etc.

Art. $5^{\circ} \mathrm{O}$ acesso à educação básica obrigatória é direito público subjetivo, podendo qualquer cidadão, grupo de cidadãos, associação comunitária, organização sindical, entidade de classe ou outra legalmente constituída e, ainda, o Ministério Público, acionar o poder público para exigi-lo.

Art. $6^{0}$ É dever dos pais ou responsáveis efetuar a matrícula das crianças na educação básica a partir dos 4 (quatro) anos de idade.

Art. 14. Os sistemas de ensino definirão as normas da gestão democrática do ensino público na educação básica, de acordo com as suas peculiaridades [...]

Art. 22. A educação básica tem por finalidades desenvolver o educando, assegurarlhe a formação comum indispensável para o exercício da cidadania e fornecer-lhe meios para progredir no trabalho e em estudos posteriores. ${ }^{218}$

O cenário do Congresso Nacional caracterizou-se por uma disputa na arena de poder na qual se aglutinaram forças ligadas aos educadores representados pelo Fórum e outros parlamentares que acolhiam interesses dos empresários e lobistas do ensino privado.

Enquanto, de um lado estavam os educadores de tendência educacional da Escola Nova com "matrizes do ideário liberal que defendia o Estado laico e democrático, visando à reconstituição da Nação Republicana por meio da educação e pleiteava a instalação da escola básica única e gratuita para todos os brasileiros". De outro lado, os intelectuais católicos, "mantendo o ideário da Pedagogia Tradicional, conservadora, acrítica, como pilar de suas ações discriminadoras e não emancipatórias, pois a escola básica, segundo esses católicos leigos deveria servir aos filhos das classes privilegiadas”. ${ }^{219}$

\footnotetext{
${ }^{217}$ Idem, p. 34.

${ }^{218}$ BRASIL. Lei $\mathbf{n}^{\mathbf{0}}$ 9.394, de 20 de dezembro de 1996. Estabelece as diretrizes e bases da educação nacional. Disponível em: <http://www.planalto.gov.br/ccivil_03/LEIS/L9394.htm>. Acesso em: 2 dez. 2013.

${ }^{219}$ BRZEZINSKI, I. Tramitação e desdobramentos da LDB/1996: embates entre projetos antagônicos de sociedade e de educação. Trab. Educ. Saúde, Rio de Janeiro, v. 8 n. 2, p. 185-206, jul./out.2010, p. 189.
} 
Darcy Ribeiro, político, educador, antropólogo signatário do mesmo "Manifesto dos Educadores Democratas em Defesa do Ensino Público" (1959), possuía credenciais que o legitimavam a ser respeitado tanto no meio educacional quanto na arena parlamentar.

Na verdade, acredita-se que, sob a ótica de político, estadista e pensador da educação, que além de ter participado da formulação de sistemas educacionais de outras nações, já havia também sido ministro da educação, vice-governador, candidato a governador e senador, talvez Darcy lograva vislumbrar horizontes infinitamente mais elevados que os bem-intencionados educadores participantes do Fórum Nacional em Defesa da Escola Pública.

$\mathrm{Na}$ verdade, tendo sido levado à causa da educação por Anísio Teixeira, “desde que abraça a causa da educação, na década de 1950, Darcy Ribeiro mantém sua imagem de intelectual público, atrelada à intervenção e à elaboração de políticas educacionais.”220 Inclusive, ressalte-se que a influência de Anísio Teixeira no projeto de LDB proposto por Darcy torna-se explícita no teor dos artigos 61 a 66, que dispõem sobre a formação dos profissionais da educação e a instituição dos Institutos Superiores de Educação, seu antigo anseio.

Portanto, quiçá ele conseguia enxergar no projeto originalmente proposto na Câmara dos Deputados, certas potencialidades prejudiciais ou danosas aos destinatários da educação, principalmente, a básica. A razão disso é que o educador e político Darcy Ribeiro concebia a educação brasileira do ponto de vista civil, em outras palavras, ele a pensava pela perspectiva do aluno e não dos educadores somente.

A partir da análise do processo de tramitação da Lei de Diretrizes e Bases da Educação no Congresso Nacional, pode-se constatar nitidamente o posicionamento, a dinâmica e os embates entre as forças políticas que ali atuaram como representantes de grupos socioeconômicos com orientações de um lado conservadoras e de outro lado progressistas.

Consequentemente, ao longo de oito anos, desnaturou-se o enfoque progressista que, no projeto original da autoria do deputado Octávio Elísio,

\footnotetext{
${ }^{220}$ BOMENY, H. Darcy Ribeiro: sociologia de um indisciplinado. Belo Horizonte: UFMG, 2001,
} p. 122. 
estruturava a educação básica, conformando-a ao sabor das correntes hegemônicas de viés conservador.

Cumpre salientar que esse processo repleto de tensões e embates ocorridos nos bastidores do Congresso Nacional foi ocasionado por tramas e conluios que envolveram a correlação de forças sociopolíticas oriundas do Legislativo, do Executivo, da sociedade civil organizada, do lobby confessional e, principalmente, da iniciativa privada.

Em outras palavras, a atual burguesia nacional agiu de maneira semelhante à atuação da sua precursora no cenário conturbado da França revolucionária, contribuindo, assim, para a polarização dos debates e das disputas em torno da formulação da nova norma destinada a reformar o sistema educacional nacional.

Em suma, a tramitação da LDB/1996 caracterizou-se pela disputa ideológica entre o público e o privado, focando o conflito entre a defesa da escola pública, laica, gratuita para todos e de qualidade em todos os níveis de escolarização, e o ensino privado, promovido pelos empresários que visam transformar em mercadoria o direito à educação preceituado na Constituição de 1988. ${ }^{221}$

Inegavelmente, a conflituosa questão público-privado revelou-se atual tanto na tramitação da seção sobre educação na constituinte de 1987-1988, quanto na formulação da nova Lei de Diretrizes e Bases da Educação Nacional. Havia disputas em relação à gratuidade e à laicidade do ensino e à exclusividade de recursos públicos para a escola pública.

Tais reivindicações foram quase todas acolhidas pelo projeto final aprovado pela Subcomissão de Educação, Cultura e Esportes e mantidas em sua quase total plenitude. Já na fase das Comissões Temáticas, houve um equilíbrio de forças entre progressistas e conservadores. ${ }^{222}$

Saviani conclui que "a cumplicidade entre o público e o privado é própria da sociedade capitalista” e o pior é que nessa realidade social, "o público tende a estar a serviço de interesses privados, uma vez que se trata de uma forma social

\footnotetext{
${ }^{221}$ BRZEZINSKI, I. Tramitação e desdobramentos da LDB/1996: embates entre projetos antagônicos de sociedade e de educação. Trab. Educ. Saúde, Rio de Janeiro, v. 8 n. 2, p. 185-206, jul./out.2010, p. 190.

${ }^{222}$ PINHEIRO, M. F. O público e o privado na educação: um conflito fora de moda. In: FÁVERO, O. (Org.) A educação nas constituintes brasileiras 1823-1988. Campinas, SP: Autores Associados, 1996, p. 273-275.
} 
dominada pela classe que detém a propriedade privada dos meios de produção”. Contudo, os maiores avanços no âmbito educacional se deram nos países que "mais se aproximaram do sentido republicano" ao assegurarem sistemas educativos baseados no direito à educação como dever do estado. ${ }^{223}$

A partir da consulta às atas de reuniões desta subcomissão sobre a tramitação da LDB, empreende-se uma análise sobre os debates legislativos travados entre os parlamentares de correntes antagônicas.

Portanto, inicialmente, quando se analisa o Projeto de Lei ${ }^{0} 1.258$ de 1988 apresentado pelo deputado constituinte Octávio Elísio na $35^{\mathrm{a}}$ sessão, em 10 de abril de 1989, o primeiro aspecto que salta aos olhos é exatamente o reconhecimento da influência dos princípios e ideais característicos da Revolução Francesa no teor do artigo $1^{\circ}$.

Nele pode-se ler que a educação nacional é “inspirada nos ideais de igualdade e de liberdade” e "nos ideais democráticos e nos ideais de solidariedade humana”. Assim, pode-se constatar que, além de assumir e reafirmar os ideais semelhantes ao projeto de educação proposto pelo movimento revolucionário francês, esse dispositivo legal até mesmo emprega termos típicos do jargão das Declarações do Homem e do Cidadão, pois inclui palavras e expressões tais como “direitos” e “deveres”, “pessoa humana”, “cidadão”, etc. ${ }^{224}$

Indubitavelmente, ainda no teor do artigo $1^{\circ}$ parece haver uma nítida alusão à “onilateralidade” do homem defendida por Karl Marx, pois declara-se que a educação nacional possui a finalidade de promover “a formação de seres humanos plenamente desenvolvidos".225

Além disso, mais uma vez confirmando a hipótese de que há um legado deixado pela Revolução Francesa, não há como negar a semelhança entre o teor do artigo $2^{\circ}$ do referido projeto de lei e o artigo 22 da Declaração dos Direitos do Homem e do Cidadão de 1793 quando preconiza que “A educação é direito de

\footnotetext{
${ }^{223}$ SAVIANI, D. O Estado e a promiscuidade entre o público e o privado na história da educação brasileira. In: SAVIANI, D. (Org.). Estado e políticas educacionais na história da educação brasileira. Vitória: EDUFES, 2010, p. 40-41.

${ }^{224}$ AGUIAR, U. D.; MARTINS, R. C. R. LDB: memória e comentários. Fortaleza: Universidade Federal do Ceará, 1998, p. 163.

${ }^{225}$ Idem, p. 163.
} 
todos e será promovida e incentivada por todos os meios legítimos disponíveis na sociedade”. 226

Também merece destaque o teor do Artigo $4^{\circ}$ que disciplina o dever do Estado e a liberdade de educar da iniciativa privada. Por sua vez, o artigo $3^{\circ}$ garante a gratuidade do ensino com pleno acesso a todos os cidadãos.

Além disso, o artigo $3^{\circ}$ pressupõe igualdade de oportunidades e acesso ao ensino, através de "um sistema nacional da educação mantido pelo poder público, gratuito em todos os níveis, aberto e acessível a todos os brasileiros”. 227

A longa trajetória de elaboração legislativa da LDB em ambas as casas do Congresso Nacional revela como as etapas do processo legislativo tende a ser moroso e pouco produtivo. A procrastinação, os quase infindáveis debates e negociações, a imensa gama de emendas apresentadas ao longo dos 8 anos de tramitação da LDB, atestam claramente contra a tão propalada eficiência do Parlamento nacional ao longo do processo legislativo.

Por outro lado, há quem afirme que tal lentidão do Congresso Nacional deve ser considerada como uma expressão do esmero empregado na procura do melhor projeto para a educação nacional e não se tratava em hipótese alguma de uma atitude de indolência ou desídia para com a educação pública.

Contudo, de qualquer maneira, Jorge Hage considerou que esse período, os parlamentares do Congresso Nacional tiveram a oportunidade de ouvir propostas e sugestões, atenuar diferenças e fazer convergir concepções e perspectivas de educação a princípio contrárias. Como essência do processo democrático, tiveram que colocar as discrepâncias à luz do amplo debate, promover o consenso e, finalmente, aceitar a decisão da maioria pela excelência. ${ }^{228}$

Embora bastante sucinto, o projeto de Darcy Ribeiro caracterizou-se por reproduzir as disposições constitucionais concernentes ao direito à educação e ao dever de educar, além de princípios e fins da educação nacional. ${ }^{229}$

A grande diferença do projeto de Darcy Ribeiro situava-se nos níveis e modalidades da educação. Tratava-se de modificar a estrutura do ensino

\footnotetext{
${ }^{226}$ Idem, p. 163.

${ }^{227}$ AGUIAR, U. D.; MARTINS, R. C. R. LDB: memória e comentários. Fortaleza: Universidade Federal do Ceará, 1998, p. 163.

${ }^{228}$ BRASIL. Diário do Congresso Nacional de 06 de dezembro de 1996, p. 32258.

${ }^{229}$ Op. Cit., p. 58.
} 
fundamental e médio, passando o primeiro a ter cinco anos de duração e o segundo, dividido em ginásio, com duração de cinco anos, e curso preparatório para o ensino superior, com duração de um ou dois anos, de acordo com a carreira pretendida. Tal estrutura assemelhava-se muito à adotada pela reforma educacional de Francisco Campos, em 1931. A leitura do texto, bem como do discurso que o apresentou, evidencia o ânimo de retomar algumas ideias defendidas por Anísio Teixeira, para o qual o ensino primário (no caso o ensino fundamental) seria o básico obrigatório para todo cidadão. Já o ensino médio teria como cerne o ginásio, ciclo de estudos terminal, compondo uma escolarização global de dez anos, com o ensino fundamental. Os cursos preparatórios para o ensino superior seriam como estudos adicionais.

Contudo, o texto ainda previa princípios disciplinadores da gestão democrática do ensino público. Assim, preconizava a integração entre os sistemas educacionais e as famílias e as comunidades, a participação democrática no processo educacional, a atuação majoritária de docentes em órgãos colegiados, o autofinanciamento da iniciativa privada, a atuação prioritária das esferas da Administração Pública (ensino fundamental e educação infantil com os municípios; ensino médio e formação de educadores com Estados e o Distrito Federal; ensino superior com a União).

Na parte específica sobre o ensino fundamental, a grande ênfase era sobre a escola de tempo integral. Priorizavam-se as áreas mais pobres e de baixo desempenho educacional, sobretudo nas áreas metropolitanas, e o atendimento às crianças de sete anos de idade. Novamente aqui se recuperavam as ideias originais de Anísio Teixeira, determinando que a escolaridade em tempo integral poderia ser oferecida por meio de escolas integradas, combinando escolas-classe e escolas-parque. [...] No campo da educação infantil, o projeto previa, além das creches e pré-escolas, casas comunitárias e centros de puericultura, mais voltadas para atividades assistenciais e sem obrigação de dar atendimento em tempo integral. [...] No capítulo sobre o ensino médio, previa-se que o ginásio deveria oferecer, além do currículo básico, já mencionado, práticas educativas de enriquecimento, através de clubes, incluindo o ensino de línguas e atividades preprofissionalizantes e profissionalizantes.

O texto que ao final foi sancionado pode ser considerado bastante progressista, apesar de ainda não ter assegurado uma educação pública de qualidade democraticamente acessível a todos mediante a devida e almejada valorização do magistério. ${ }^{230}$

\footnotetext{
${ }^{230}$ AGUIAR, U. D.; MARTINS, R. C. R. LDB: memória e comentários. Fortaleza: Universidade Federal do Ceará, 1998, p. 59.
} 
Conforme pode-se constatar, vários confrontos, embates e conflitos entre correntes defensoras de concepções opostas marcaram a morosa e complexa elaboração da norma sobre diretrizes e bases da educação nacional.

Configurada como a síntese das tensões existentes entre vertentes opostas oriundas e representando as diferentes classes socioeconômicas envolvidas no processo legislativo, seu teor tem a potencialidade para transformar o cenário educacional pátrio e, consequentemente, ampliar o acesso à plena cidadania a todos os brasileiros. 


\section{4}

\section{Considerações Finais}

Diante de todo o exposto, pode-se considerar, de forma conclusiva, que as hipóteses norteadoras propostas inicialmente e desenvolvidas ao longo do presente trabalho foram confirmadas.

Assim, primeiramente, constatou-se que o modelo constitucional característico do constitucionalismo do século XVIII realmente influenciou a organização ou o arcabouço constitucional pátrio contemporâneo. Inclusive, um claro exemplo disso é a presença de termos e expressões peculiares ou próprias do jargão típico das declarações de direitos do homem e do cidadão produzidos em pleno período revolucionário.

Inclusive, neste mesmo diapasão, vale ressaltar que o Ministro José Carlos Moreira Alves, então o Presidente do Supremo Tribunal Federal, no seu discurso na sessão de instalação da Assembleia Nacional Constituinte de 1987-1988, admitiu a existência de um vínculo entre a herança constitucional originário deixada pela Revolução Francesa e a atual organização constitucional brasileira.

Portanto, a partir da análise histórica da origem de princípios constitucionais como direitos civis e políticos e poder constituinte, constatou-se que a Revolução Francesa é um marco de extraordinária relevância no processo evolutivo do constitucionalismo. Após a apreciação da ideologia revolucionária francesa que inclusive rompeu fronteiras, conclui-se que o constitucionalismo contemporâneo não pode ser compreendido em toda a sua extensão sem considerar os eventos que ensejaram a eclosão da Revolução Francesa.

Ao defender a abolição dos privilégios tradicionais da nobreza e da realeza, o movimento revolucionário francês avançou significativamente a causa do direito e da justiça. Além disso, como modificação da ordem constitucional, ao estabelecer conquista de direitos individuais que aspiravam ser universais, ensejou também o advento da cidadania.

O constitucionalismo como técnica jurídica de tutela das liberdades, surgida nos fins do século XVIII, possibilitou aos cidadãos o exercício, com base em Constituições escritas, dos seus direitos e garantias fundamentais. Na transição da 
monarquia absoluta para o Estado de Direito, surgiu o modelo constitucional moderno herdeiro do legado do constitucionalismo de fins do século XVIII caracterizado pela elaboração de constituições que contemplaram a declaração e a garantia de direitos individuais, além da adoção da democracia representativa.

Diante do exposto, considera-se que o desenvolvimento do constitucionalismo como o processo de transformação do homem comum, sujeito às injustiças decorrentes da composição jurídica do regime feudal, em cidadão, cujos direitos civis e políticos passaram a ser garantidos pelas constituições e declarações de direitos. Portanto, conclui-se que é imprescindível a análise da evolução histórica do constitucionalismo a partir da identificação dos traços históricos referentes à Revolução Francesa, para a compreensão do constitucionalismo pátrio, principalmente o direito à educação básica.

Tendo analisado o processo de discussão e formação dos dois diplomas legais normativos garantidores do direito fundamental à educação básica: a (Constituição Federativa de 1988 e a Lei no 9.394, de 20 de dezembro de 1996 LDB). Deste modo, investigaram-se os específicos pontos de conflito que geraram divergências e confrontos políticos referentes a educação básica tanto na Assembleia Nacional Constituinte de 1987-1988 quanto no Congresso Nacional no período de deliberação sobre a LDB.

Inclusive, os tópicos que geraram mais divergência e antagonismo entre os parlamentares representantes ou alinhados com concepções conservadoras ou progressistas de educação foram: escola pública e privada; laicidade da educação, gratuidade do ensino.

Após traçar o eixo norteador proposto que incorporou questões cruciais envolvidas nesse processo de elaboração do aparato jurídico garantidor do direito à educação básica no Brasil. Esse percurso incluiu o exame da herança oriunda do contexto histórico e político-ideológico da França revolucionária do final do século XVIII, que também caracterizou-se pela mesma dicotomia entre correntes políticas progressistas e conservadoras. Inclusive, constatou-se a ressonância dos confrontos revolucionários franceses concernentes à concepção de educação na visão político-ideológica. 
Além disso, atestou-se o caráter ambivalente da educação, ou seja, sua capacidade de agir como elemento transformador da realidade social ou promover o controle e a disciplina do ser humano. Portanto, conclui-se que essa ambivalência é uma propriedade intrínseca da educação que pode ser empregada segundo a tônica progressista ou conservadora defendida conforme os interesses e a posição político-ideológica daqueles que exercem o poder.

Em outras palavras, constatou-se que ela pode ser considerada como um elemento de reintegração da onilateralidade e da emancipação humana. inclusive, constatou-se que, por outro lado, a educação pode ser transformada em um instrumento de dominação burguesa e aparelho ideológico do Estado capitalista no âmbito da sociedade disciplinar.

Além disso, após a apreciação da teoria constitucional, conclui-se que o direito fundamental à educação, uma vez incorporado ao direito positivo através da mediação do poder político do Estado, torna-se um instrumento imprescindível para que o indivíduo desenvolva todas suas potencialidades na sociedade.

Após a apreciação da argumentação crítica sobre a atuação dos Aparelhos Ideológicos de Estado proposta por Althusser, torna-se inevitável também concluir que a escola, em todas as suas facetas e níveis, configura-se como o principal AIE capitalista dominante nas formações sociais. Assim, o AIE escolar está a serviço da criação, reprodução, manutenção e perpetuação das relações de dominação típicas da sociedade capitalista.

Ademais, conclui-se que é imprescindível a análise da contribuição teórica proposta por Foucault. É inquestionável a relevância e a pertinência das ideias desse autor sobre a noção de sociedade disciplinar, micropoderes, normalização e sua função de objetivação do sujeito na modernidade através de elementos da genealogia desenvolvida por esse ilustre pensador.

A escola tem se tornado um poderoso instrumento de promoção e manutenção da hegemonia burguesa capitalista. Contudo, por outro lado, correntes contra-hegemônicas defendem uma educação crítica que promova a emancipação dos cidadãos. Estas vertentes buscam a construção de uma realidade social sob uma perspectiva emancipadora com vistas à efetividade de um processo educativo fundamentado nos princípios de igualdade e democracia. 
Pesquisando as origens do direito à educação, conclui-se pelos seus reflexos na perspectiva educacional revolucionária. Por outro lado, considerando o caráter ambivalente da educação, examinaram-se também os fundamentos e efeitos da dominação perpetrada pela elite burguesa capitalista mediante a manipulação da educação.

Propôs-se uma reflexão sobre os processos que caracterizam a escola como instrumento do Poder Disciplinar e da dominação perpetrada pela burguesia mediante a utilização dos Aparelhos Ideológicos de Estado. Além disso, empreende-se um exame histórico da abordagem constitucional do tema educação. Realmente, os embates políticos e ideológicos travados em torno desse tema na Assembleia Constituinte de 1987-1988, assim como nas comissões encarregadas de formular o projeto que resultou na atual LDB foi enriquecedor.

Cumpre salientar, mais uma vez, a posição de relevância que tais argumentações filosóficas e as disputas parlamentares assumem ao desnudarem a trama ideológica que se dá em torno da efetividade desse direito fundamental previsto na Constituição.

Considerando o liame entre o legado constitucionalista francês e o atual modelo constitucional pátrio, apresentou-se um panorama retrospectivo da educação básica ao longo da história do constitucionalismo brasileiro. Em seguida, analisou-se o contexto político e parlamentar das discussões e confrontos concernentes ao teor da seção sobre a educação nas comissões da Assembleia Constituinte de 1987-1988. Depois, examinou-se o cenário parlamentar produtor da atual Lei de Diretrizes e Bases da Educação Nacional.

Constatou-se que a concepção de educação sustentada por representantes de alguns segmentos políticos está organizada segundo os interesses da classe burguesa e não refletem as carências das classes desfavorecidas, perpetuando, assim a segregação através da monopolização do sistema educacional.

O estudo das atas da Assembleia Nacional Constituinte de 1987-1988 possibilitou a constatação da existência de duas correntes antagônicas: uma de caráter conservador e outra de natureza progressista. Inclusive, verificou-se que as discussões realizadas na Subcomissão de Educação, Cultura e Esportes caracterizaram-se pelo confronto entre vertentes progressistas e conservadoras 
opostas. Assim, evidenciou-se o caráter ambivalente que a educação pode assumir, ora favorecendo a transformação social e a onilateralidade humana e a expansão do acesso democrático à escola, ora ao sabor das classes sociais dominantes.

A hipótese do legado constitucional francês, vale assinalar que o teor do Projeto de Lei do constituinte Octávio Elísio remete à inspiração dos ideais democráticos e de solidariedade. Ademais, constatou-se que, além de ratificar os ideais do projeto de educação proposto pela Revolução Francesa, o texto até mesmo lança mão de termos próprios do jargão das Declarações do Homem e do Cidadão tais como “direitos” e “deveres”, “pessoa humana”, “cidadão”, etc.

A semelhança entre o teor do artigo $2^{\circ}$ do referido projeto de lei e o artigo 22 da Declaração dos Direitos do Homem e do Cidadão de 1793 é interessante, pois que enfatizam a educação como direito de todos a ser promovida por todos os meios disponíveis. Também merece destaque o teor do Artigo 4o que disciplina o dever do Estado e a liberdade de educar da iniciativa privada. Por sua vez, o artigo $3^{\circ}$ garante a gratuidade do ensino com pleno a cesso a todos os cidadãos. Além disso, no teor do artigo 1o parece haver uma clara referência à "onilateralidade" humana sustentada por Marx, pois afirma-se que a educação visa promover "a formação de seres humanos plenamente desenvolvidos”.

Contudo, é inegável que a tramitação da LDB foi demasiadamente longa. Isso implica na lentidão causada por prolongadas discussões, novas eleições ao longo de oito anos que renovava boa parte do Congresso Nacional que pode ter sua eficiência questionada. Por outro lado, na ótica do constituinte Jorge Hage tal período possibilitou aos membros do Congresso Nacional ouvir propostas e sugestões, amenizar divergências e tentar conciliar concepções de educação a princípio opostas.

À guisa de conclusão, pode-se considerar que essa rota traçada para investigar a gênese dos instrumentos de promoção do direito fundamental à educação possibilitou a compreensão da relevância do estudo do processo legislativo para o alcance do real significado dos diplomas normativos em questão. Com efeito, o exame das conquistas dessa fase histórica do 
constitucionalismo pode contribuir não somente para o entendimento do presente, mas também para a construção de um futuro digno para a educação básica. 


\section{Referências Bibliográficas}

AGUIAR, Ubiratan Diniz de; MARTINS, Ricardo Chaves de Rezende. LDB: memória e comentários. Fortaleza: Universidade Federal do Ceará, 1998.

ALTHUSSER, Louis. Aparelhos ideológicos de Estado: nota sobre os aparelhos ideológicos de Estado (AIE). 6. ed. Rio de Janeiro: Graal, 1992.

Ideologia e aparelhos ideológicos do Estado. 3. ed. Lisboa: Presença/Martins Fontes, 1980.

ALVES, Márcio Moreira. O Beabá dos MEC-USAID. Rio de Janeiro: Gernasa, 1968.

BABEUF, Graco. O manifesto dos iguais. Disponível em: $<$ https://www.marxists.org/portugues/babeuf/1796/mes/manifesto.htm>. Acesso em: 2 nov. 2013.

BARBOSA, Rui. Oração aos moços. 5. ed. Rio de Janeiro: Fundação Casa de Rui Barbosa, 1997.

BOMENY, Helena. Darcy Ribeiro: sociologia de um indisciplinado. Belo Horizonte: UFMG, 2001.

BOTO, Carlota. A escola do homem novo: entre o Iluminismo e a Revolução Francesa. São Paulo: UNESP, 1996.

BOURDIEU, Pierre. A escola conservadora: as desigualdades frente à escola e à cultura. In: NOGUEIRA, Maria Alice; ATANI, Afrânio (Orgs.). Escritos de educação: 5. ed. Rio de Janeiro: Vozes, 2003.

BRASIL. Ata da Assembleia Nacional Constituinte de 2 de fevereiro de 1987. Diário da Assembleia Nacional Constituinte. Ano XLII, n. 001. Brasília.

Ata da $194^{\mathrm{a}}$ Sessão da Assembleia Nacional Constituinte em 4 de fevereiro de 1988. Diário da Assembleia Nacional Constituinte de 5 de fevereiro de 1987.

Ata da $13^{\mathrm{a}}$ Reunião Ordinária da Subcomissão dos Direitos Políticos, dos Direitos Coletivos e Garantias realizada em 14 de maio de 1987. Diário da Assembleia Nacional Constituinte de 8 de julho de 1987. Ano I - Suplemento ao n 90. Brasília, 1987.

Ata da $2^{\mathrm{a}}$ Reunião Ordinária da Comissão VIII. Diário da Assembleia Nacional Constituinte de 25 de maio de 1987.

Ata da $5^{\mathrm{a}}$ Reunião Ordinária da Comissão VIII. Diário da Assembleia Nacional Constituinte de 28 de maio de 1987. 
Ata da $13^{\mathrm{a}}$ Reunião Ordinária da Subcomissão dos Direitos Políticos, dos Direitos Coletivos e Garantias realizada em 14 de maio de 1987. Diário da Assembleia Nacional Constituinte de 8 de julho de 1987. Ano I - Suplemento ao $n^{\circ}$ 90. Brasília.

Constituição (1988). Constituição da República Federativa do Brasil, promulgada em 05 de outubro de 1988. Disponível em: $<$ http://www.planalto.gov.br/ccivil_03/constituicao/constituicao.htm >. Acesso em: 2 dez. 2013.

Constituição (1937). Constituição dos Estados Unidos do Brasil, promulgada em 10 de novembro de 1937. Disponível em: < http://www.planalto.gov.br/ccivil_03/constituicao/constituicao37.htm>. Acesso em: 2 dez. 2013.

Constituição (1934). Constituição da República dos Estados Unidos do Brasil, promulgada em 16 de julho de 1934. Disponível em: $<$ http://www.planalto.gov.br/ccivil_03/constituicao/constituicao34.htm>. Acesso em: 2 dez. 2013.

Lei $n^{0}$ 4.024, de 20 de dezembro de 1961. Fixa as diretrizes e bases da educação nacional. Disponível em: <http://www.planalto.gov.br/ccivil_03/leis/14024.htm >. Acesso em: 2 dez. 2013.

Lei $n^{0}$ 9.394, 20 de dezembro de 1996. Estabelece as diretrizes e bases da educação nacional. Disponível em: <http://www.planalto.gov.br/ccivil_03/leis/19394.htm>. Acesso em: 2 dez. 2013.

BRZEZINSKI, Iria. Tramitação e desdobramentos da LDB/1996: embates entre projetos antagônicos de sociedade e de educação. Trab. Educ. Saúde, Rio de Janeiro, v. 8 n. 2, p. 185-206, jul./out.2010.

BUFFA, Ester; ARROYO, Miguel G.; NOSELLA, Paolo. (Orgs.). Educação e cidadania: quem educa o cidadão? 13. ed. São Paulo: Cortez, 2007.

BURKE, Edmund. Reflexões sobre a revolução em França. Brasília: UnB, 1982.

CATTANI, Antonio David. Libertários e tutelares no mundo do trabalho. Tempo Social; Rev. Sociol. USP: São Paulo, 14(2): 71-81, out. 2002, p. 75.

CHIZZOTTI, Antonio. A constituinte de 1823 e a educação. In: FÁVERO, Osmar (Org.) A educação nas constituintes brasileiras: 1823-1988. 2. ed. Campinas: Autores Associados, 2001.

CONSTANT, Benjamin. Da liberdade dos antigos comparada à dos modernos (1819). In: MORAES, João Quartim (Org.) Revista Filosofia Política. Porto Alegre: L\&PM, 1985.

COMPARATO, Fábio Konder. A afirmação histórica dos direitos humanos. 7. ed. São. Paulo: Saraiva, 2010. 
COTRIM, Gilberto. História global - Brasil e geral. 8. ed. São Paulo: Saraiva, 2005.

CRETELLA JÚNIOR, J. Comentários à constituição brasileira de 1988. 2. ed. Rio de Janeiro: Forense Universitária, 1993.

CRITELLI, Dulce Mára. Educação e dominação cultural: tentativa de reflexão ontológica. 2. ed. São Paulo: Cortez, 1981.

CURY, Carlos Roberto Jamil. A educação e a primeira constituinte republicana. In: FÁVERO, Osmar. (Org.) A educação nas constituintes brasileiras: 18231988. 2. ed. Campinas: Autores Associados, 2001.

DEIRÓ, Pedro Eunápio da Silva. Fragmentos de estudos da história da Assembleia Constituinte do Brasil. Brasília: Senado Federal, 2006.

ENGUITA, Mariano Fernández. A face oculta da escola: educação e trabalho no capitalismo. Porto Alegre: Artes Médicas, 1989.

Trabalho, escola e ideologia: Marx e a crítica da educação. Porto Alegre: Artes Médicas Sul, 1993.

FARENZENA, Nalú. Assembleia Nacional Constituinte de 1987-1988, educação e cidadania: entrevista com Hermes Zanetti. RBPAE - v.24, n.2, mai./ago. 2008.

FERNANDES, Florestan. Depoimento. In: Memória viva da educação brasileira. v. 1. Brasília: Inep, 1991.

FOUCAULT, Michel. A ordem do discurso. 9. ed. São Paulo: Loyola, 2003.

. Em defesa da sociedade: curso no Collège de France. São Paulo: Martins Fontes. 2002.

Vigiar e punir: nascimento da prisão. Petrópolis: Vozes, 1999.

FREIRE, Paulo. Educação e mudança. Rio de Janeiro: Paz e Terra, 1979.

FRIGOTTO, Gaudêncio. Educação e a crise do capitalismo real. 5. ed. São Paulo: Cortez, 2003.

GADOTTI, Moacir. História das ideias pedagógicas. 6. ed. São Paulo: Ática, 1998.

GERIBELLO, Vanda Pompeu. Anísio Teixeira: análise e sistematização de sua obra. São Paulo: Atlas, 1977.

HOBSBAWM, Eric. A era das revoluções: 1789-1848. Rio de Janeiro: Paz e Terra, 1981.

. Ecos da Marselhesa: dois séculos reveem a Revolução Francesa. São Paulo: Companhia das Letras, 1996. 
(Org.). História do marxismo. 3. ed. Rio de Janeiro: Paz e Terra, 1983.

IANNI, Octavio (Org.). Karl Marx: sociologia. 8. ed. São Paulo: Ática, 1996.

JOAQUIM, Nelson. Direito educacional brasileiro: história, teoria e prática. 1. ed. Rio de Janeiro: Livre Expressão, 2009.

LIMA, Hermes. Anísio Teixeira: Estadista da Educação. Rio de Janeiro: Civilização Brasileira, 1978.

1935.

Problemas de nosso tempo. São Paulo: Companhia Editora Nacional,

LIMA, Luziano Pereira Mendes de. A atuação da esquerda no processo constituinte: (1986-1988). Brasília: Câmara dos Deputados, 2009.

MACHADO NETO, Antônio Luís. Sociologia jurídica. 6. ed. São Paulo: Saraiva, 1987.

MANACORDA, Mario Alighiero. Marx e pedagogia moderna. São Paulo: Cortez, 1991.

MANFRED, Albert Zakharovich. A concepção materialista da Revolução Francesa. São Paulo: Global, 1982.

MARTINS, Carlos Benedito. A reforma universitária de 1968 e a reabertura para o ensino superior privado no Brasil. In: Educ. Soc., Campinas, vol. 30, n. 106, p. 15-35, jan./abr. 2009.

MARX, Karl; ENGELS, Friedrich. Crítica da educação e do ensino. Lisboa: Moraes, 1978.

MORAES, Alexandre de. Direito constitucional. 28. ed. São Paulo: Atlas, 2012.

NEGRI, Antonio. O poder constituinte: ensaio sobre as alternativas da modernidade. Rio de Janeiro: DP\&A, 2002.

NEVES, Lúcia Maria Wanderley. Educação e política no Brasil de hoje. 2. ed. São Paulo, Cortez, 1999.

NEVES, Maria Aparecida. Florestan Fernandes: sociologia e política pela autonomia da nação. Instituto de Pesquisas Universitárias do Rio de Janeiro: Rio de Janeiro, 2009.

OLIVEIRA, Eugênio Pacelli de. Processo e hermenêutica na tutela penal dos direitos fundamentais. Belo Horizonte: Del Rey, 2004.

O Manifesto dos Pioneiros da Educação Nova (1932). Revista HISTEDBR Online, Campinas, n. especial, p. 188-204, ago. 2006.

PEDUZZI, Maria Cristina Irigoyen. O princípio da dignidade da pessoa humana na perspectiva do direito como integridade. São Paulo: LTr, 2009. 
PILATTI, Adriano. A constituinte de 1987-1988: progressistas, conservadores, ordem econômica e regras do jogo. Rio de Janeiro: Lumen Juris, 2008.

Comentários ao texto de Maria Francisca Pinheiro. In: FÁVERO, Osmar

(Org.) A educação nas constituintes brasileiras 1823-1988. Campinas, SP: Autores Associados, 1996.

PINHEIRO, Maria Francisca. O público e o privado na educação: um conflito fora de moda. In: FÁVERO, Osmar (Org.) A educação nas constituintes brasileiras 1823-1988. Campinas, SP: Autores Associados, 1996.

PINSKY, Jaime; PINSKY, Carla Bassanezi (Org.). História da cidadania. 4. ed. São Paulo: Contexto, 2008.

PIOZZI, Patrizia. Utopias revolucionárias e educação pública: rumos para uma nova “cidade ética”. Educ. Soc., Campinas, vol. 28, n. 100. out. 2007.

POGREBINSCHI, Thamy. Emancipação política, direito de resistência e direitos humanos em Robespierre e Marx. Dados [online]. 2003, vol. 46, n.1.

RIBEIRO, Darcy. A universidade necessária. 5. ed. Rio de Janeiro: Paz e Terra, 1991.

Aos trancos e barrancos: como o Brasil deu no que deu. Rio de Janeiro: Guanabara, 1985.

ROCHA, Marlos Bessa Mendes da. Tradição e modernidade na educação: o processo constituinte de 1933-34. In: FÁVERO, O. (Org.) A educação nas constituintes brasileiras: 1823-1988. 2. ed. Campinas: Autores Associados, 2001.

RODRIGUES, Alberto Tosi. Sociologia da educação. Rio de Janeiro: DP\&A, 2000.

RODRIGUES, José. O moderno príncipe industrial: o pensamento pedagógico da Confederação Nacional da Indústria. Campinas: Autores Associados, 1998.

ROUSSEAU, Jean-Jacques. Emílio ou da educação. 3. ed. Rio de Janeiro: Bertrand Brasil, 1995.

SAVIANI, Dermeval. A nova lei da educação: trajetória, limites e perspectivas. 11. ed. Campinas: Autores Associados, 2008.

Educação: do senso comum à consciência filosófica. 14. ed. Campinas: Autores Associados, 2002.

Escola e democracia: teorias da educação, curvatura da vara, onze teses sobre a educação política. 34. ed. Campinas: Autores Associados, 2001.

O Estado e a promiscuidade entre o público e o privado na história da educação brasileira. In: SAVIANI, Dermeval. (Org.). Estado e políticas educacionais na história da educação brasileira. Vitória: EDUFES, 2010. 
Política e educação no Brasil; o papel do Congresso Nacional na legislação do ensino. 4. ed. Campinas: Autores Associados, 1999.

SCURO NETO, Pedro. Manual de sociologia geral e jurídica: lógica e método do direito, problemas sociais, comportamento criminoso, controle social. 4. ed. São Paulo: Saraiva, 2000.

SILVA, José Afonso da. Aplicabilidade das normas constitucionais. 6. ed. São Paulo: Malheiros, 2002.

2005.

Curso de direito constitucional positivo. 24. ed. São Paulo: Malheiros,

Princípios constitucionais fundamentais. In 20 anos da constituição cidadã. Cadernos Adenauer IX. Rio de Janeiro: Fundação Konrad Adenauer, 2008.

SILVA, Ligiane Aparecida da; LIMA, Rosilene de. Florestan Fernandes na comissão de educação da constituinte: a luta pela escola pública, laica e gratuita no Brasil. Disponível em: $<$ www.pucpr.br/eventos/educere/educere2009/anais/pdf/3122_1859.pdf $>$. Acesso em: 02 set. 2013.

SILVA, Wilton Carlos Lima da; CARVALHO, Alonso Bezerra de. Contribuições do materialismo histórico para a educação. In: Sociologia e educação: leituras e interpretações. São Paulo: Avercamp, 2006.

SUCUPIRA, Newton. O ato adicional de 1834 e a descentralização da educação. In: FÁVERO, Osmar (Org.) A educação nas constituintes brasileiras: 18231988. 2. ed. Campinas: Autores Associados, 2001.

TEIXEIRA, Anísio Spínola. Educação não é privilégio. 4. ed. São Paulo: Nacional, 1977.

VEIGA-NETO, Alfredo. Crise da modernidade e inovações curriculares: da disciplina para o controle, 2008. Disponível em: <sisifo.fpce.ul.pt/pdfs/sisifo7confPT.pdf>. Acesso em: 01 set. 2012.

VIEIRA, Sofia Lerche. A educação nas constituições brasileiras: texto e contexto. R. bras. Est. pedag., Brasília, v. 88, n. 219, p. 291-309, maio/ago. 2007.

VOVELLE, Michel. Breve história da Revolução Francesa. 1. ed. Lisboa: Presença, 1985.

WULF, Christoph. Antropologia da educação. Campinas: Alínea, 2005. 